\author{
UNIVERSIDADE DE SÃO PAULO \\ FACULDADE DE FILOSOFIA, LETRAS E CIÊNCIAS HUMANAS \\ DEPARTAMENTO DE GEOGRAFIA \\ PROGRAMA DE PÓS-GRADUAÇÃO EM GEOGRAFIA FÍSICA
}

\author{
ALEXANDRE MARQUES DE AGUIAR
}

Análises hidrogeomorfológicas e hidrossedimentológicas para comparação de duas bacias hidrográficas contribuintes do reservatório de Itaipu

São Paulo 


\author{
UNIVERSIDADE DE SÃO PAULO \\ FACULDADE DE FILOSOFIA, LETRAS E CIÊNCIAS HUMANAS \\ DEPARTAMENTO DE GEOGRAFIA \\ PROGRAMA DE PÓS-GRADUAÇÃO EM GEOGRAFIA FÍSICA
}

\title{
Análises hidrogeomorfológicas e hidrossedimentológicas para comparação de duas bacias hidrográficas contribuintes do reservatório de Itaipu
}

\begin{abstract}
Alexandre Marques de Aguiar
Dissertação apresentada ao Programa de PósGraduação em Geográfica Física do Departamento de Geografia da Faculdade de Filosofia, Letras e Ciências Humanas da Universidade de São Paulo, para a obtenção do titulo de Mestre em Geografia.
\end{abstract}

Orientador: Profa. Dra. Cleide Rodrigues

São Paulo 
Dedico aos meus pais, irmãos, familiares e amigos, em especial a Thais Eboli, minha companheira que prestou incansável apoio ao longo período de elaboração deste trabalho. 


\section{AGRADECIMENTOS}

A Profa. Dra. Cleide Rodrigues pela orientação demonstrada na elaboração deste estudo.

Ao departamento de Geografia da USP, em especial a secretaria da pós-graduação.

Aos colaboradores dos setores de meio ambiente e hidrologia da Itaipu Binacional pela receptividade e por terem disponibilizados dados de fundamental importância para desenvolvimento deste estudo.

Ao Grupo de Estudos do Meio Ambiente GEMA da Universidade de Maringá, por ter possibilitado minha participação em projetos de iniciação cientifica durante o período de minha graduação.

A Imagem de São José dos Campos - SP, pelo apoio durante minha participação das aulas da pós-graduação no período em que trabalhava nesta respeitada empresa.

Aos antigos amigos de Presidente Prudente - SP e Maringá - PR, e aos novos de São Paulo - SP e São José dos Campos - SP.

Aos meus familiares: os Aguiar, os Marques e recentemente os Eboli, a vocês todo meu respeito e admiração. 


\section{SUMÁRIO}

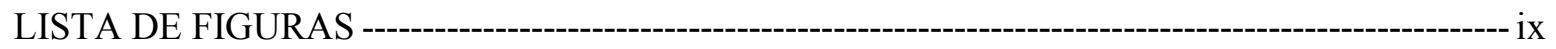

LISTA DE TABELAS ---

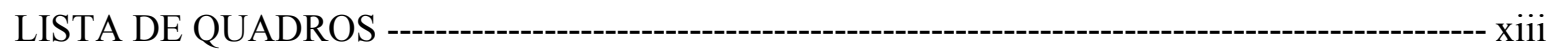

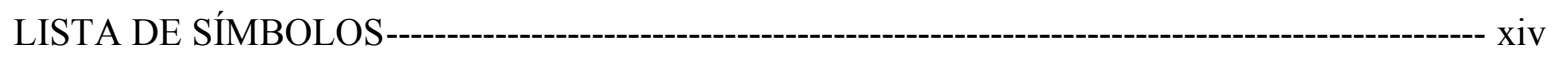

RESUMO ------ xv

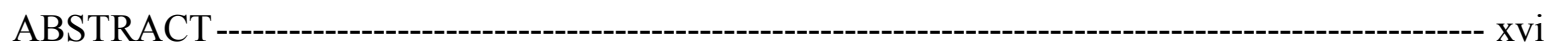

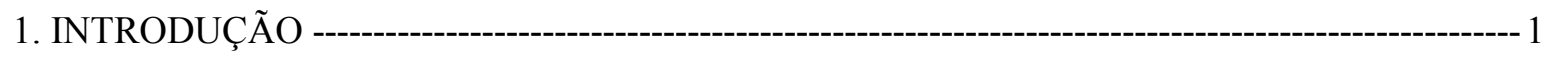

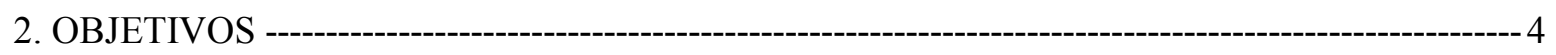

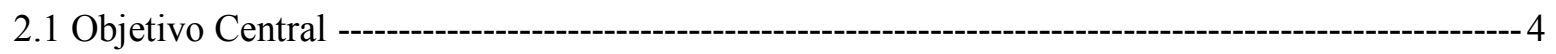

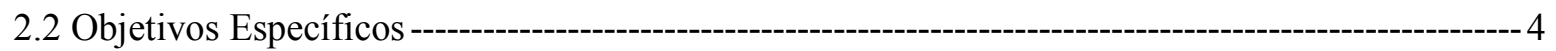

3. CARACTERIZAÇÃO DA ÁREA DE ESTUDO -

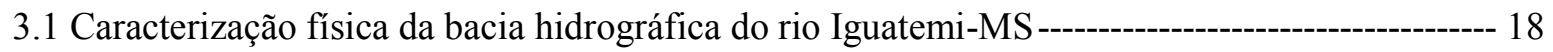

3.2 Caracterização física da bacia hidrográfica do rio Piquiri -PR--------------------------------------- 22

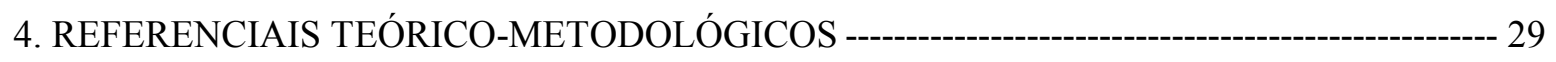

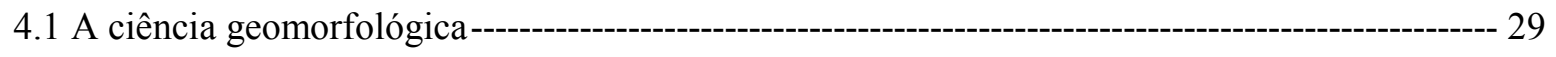

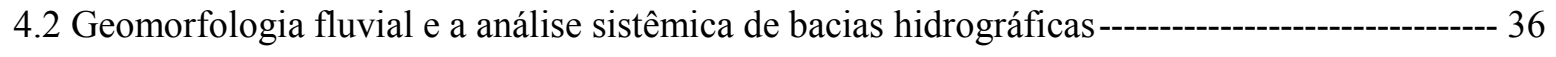

4.3 Análise morfométrica da rede de drenagem e de bacias hidrográficas --------------------------- 42

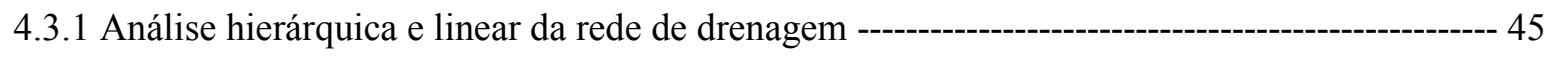

4.3.2 A análise hierárquica e areal de bacias hidrográficas ------------------------------------------------ 51

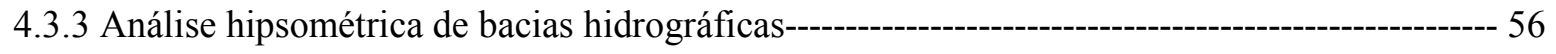

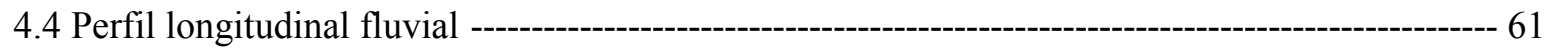

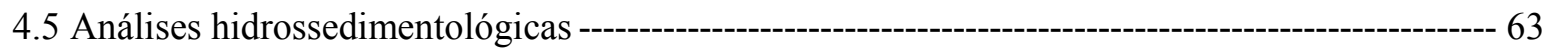

4.6 Geoprocessamento aplicado a estudos de bacias hidrográficas----------------------------------------- 67

4.7 Procedimentos técnicos para desenvolvimento das analises hidrogeomorfológicas e

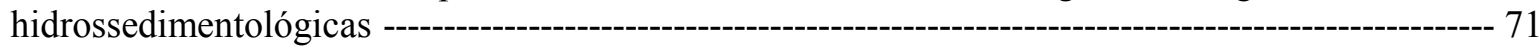




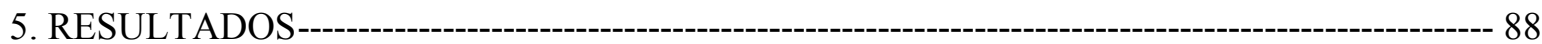

5.1 Implantação do banco de dados geográficos e processamento de modelos digitais de elevação 88

5.2 Análises comparativas das variáveis hidrogeomorfológicas --o- 97

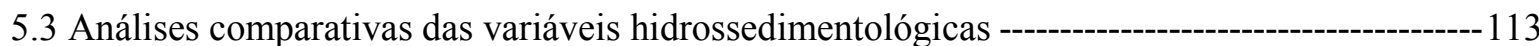

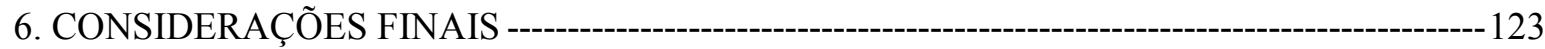

7. BIBLIOGRAFIA --126

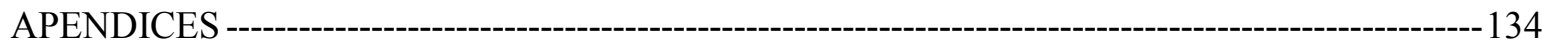

APÊNDICE A - Curva hipsográfica e de volume ---_-

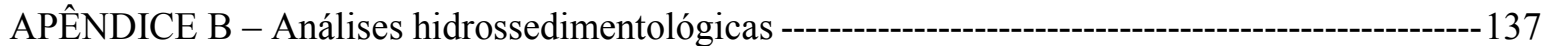




\section{LISTA DE FIGURAS}

Figura 1: Localização da área de estudo. Fonte: Mosaico de Imagens Landsat TM 5 e Hidro Web ANA (Agência Nacional de Águas). Org. Aguiar (2009). ---o-'-

Figura 2: Sistema em cascata dos reservatórios dos rios Paraná, Paranapanema e Tietê, Org:Aguiar (2009). - - Sistema en cascata dos reservatórios dos rios Paraná, Paranapanema Tiete, Org:Agure

Figura 3: Distribuição espacial das dezoito quedas dos "Saltos del Guaira". Fonte: Andrade (1942).

Figura 4: Feições geomorfológicas atualmente submersas no rio Paraná. Fonte: Prefeitura Municipal de Guaíra, PR.

Figura 5: Cânion originado por falhamentos dos derrames rochosos. Fonte: Prefeitura Municipal de Guaíra, PR.

Figura 6: Ponte Ayrton Senna - Guaíra PR, área dos submersos "Saltos del Guaíra”. Fonte:

Fantucci (2008).

Figura 7. Áreas de confluências dos rios Iguatemi e Piquiri, com o Paraná a montante da barragem de Itaipu. Org: Aguiar (2009).

Figura 8: Bacia hidrográfica do rio Iguatemi - MS. Fonte:HidroWeb ANA.Org: Aguiar (2009). -- 18

Figura 9: Localização da área de confluência do rio Iguatemi-MS com o rio Paraná. Fonte: Imagem Digital Globe, Org: Aguiar (2009). 19

Figura 10: Geologia da bacia hidrográfica do rio Iguatemi-MS. Fonte: CPRM (2001). Org: Aguiar (2009). 20

Figura 11: Localização da bacia hidrográfica do rio Piquiri-PR. Fonte: HidroWeb ANA.

Org: Aguiar (2009). 22

Figura 12: Localização da área de confluência do rio Piquiri - PR com o rio Paraná, Fonte: Digital Globe, "quick look" composição RGB (321) da imagem do satélite "Quick Bird" de 28/02/2007. Org: Aguiar (2009).

Figura 13: Foto do rio Piquiri, capturada sobre a ponte de acesso a Palotina - PR.------------------- 24

Figura 14: Geologia da bacia do rio Piquiri. Org: Aguiar (2009). Fonte Mineropar (2003). --------- 25

Figura 15: Distribuição das unidades geomorfológicas da bacia hidrográfica do rio Piquiri. Fonte

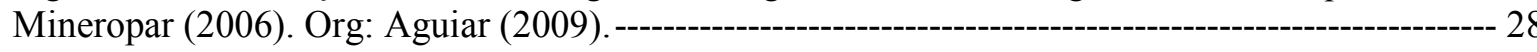

Figura 16: Comparação entre a metodologia de Horton e Strahler para ordenação da rede de

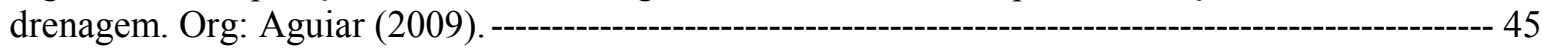

Figura 17: Curva hipsográfica, adaptado de Strahler (1957). Org: Aguiar (2009).------------------- 59

Figura 18: Procedimentos técnicos. Org: Aguiar (2009).-- 71 
Figura 19: Fluxograma de procedimentos para processamento digital dos MDE SRTM. Org: Aguiar (2009).

Figura 20: Resultado do refinamento do MDE SRTM. Org: Aguiar (2009). 76

Figura 21: Relevo realçado produzido no Erdas Imagine por meio da função "Painted Relief". Org: Aguiar (2009). 77

Figura 22: Geração do mapa de declividade em classes de porcentagem por meio do software ArcGis 9.2. Org: Aguiar (2009).78

Figura 23. Geração do mapa hipsométrico por meio do software ArcGis 9.2. Org: Aguiar (2009). 79

Figura 24: Interface dos parâmetros de entrada para emprego do Watershed Delineation. 80

Figura 25: Interface de parâmetros de entrada para inferência de fluxo e hierarquização da rede de drenagem. 80

Figura 26: Componentes do banco de dados geográficos provenientes do desenvolvimento da pesquisa. Org: Aguiar (2009).--.- 88

Figura 27: Mapa hipsométrico da bacia hidrográfica do rio Iguatemi - MS. Org: Aguiar (2009).-- 90

Figura 28: Mapa hipsométrico da bacia hidrográfica do rio Piquiri - PR. Org: Aguiar (2009). ----- 91

Figura 29: Mapa de declividades da bacia hidrográfica do rio Iguatemi - MS. Org: Aguiar (2009).

Figura 30: Mapa de declividades da bacia hidrográfica do rio - PR. Org: Aguiar (2009).------------ 92

Figura 31: Representação tridimensional da bacia hidrográfica do rio Iguatemi - MS.Org: Aguiar (2009). 95

Figura 32: Representação tridimensional da bacia hidrográfica do rio Piquiri - PR.Org: Aguiar (2009). 96

Figura 33: Rede de drenagem com hierarquia dos canais e limite da bacia hidrográfica do rio Iguatemi - MS. Org: Aguiar (2009). 97

Figura 34: Rede de drenagem com hierarquia dos canais e limite da bacia hidrográfica do rio Piquiri - PR. Org: Aguiar (2009).--- 98

Figura 35: Classificação das áreas de drenagem direta por ordem de canais da bacia do rio Iguatemi - MS. Org: Aguiar (2009). ---

Figura 36: Classificação das áreas de drenagem direta por ordem de canais da bacia do rio Piquiri -

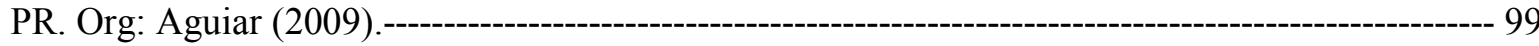

Figura 37 - Relação hierárquica x número de canais x extensão médias dos canais de cada $\mathrm{x}$ área média de drenagem dos canais por ordem de canais da bacia hidrográfica do rio Iguatemi - MS.-101 
Figura 38 - Relação hierárquica x número de canais x extensão médias dos canais de cada $\mathrm{x}$ área média de drenagem dos canais por ordem de canais da bacia hidrográfica do rio Piquiri - PR. ----101

Figura 39 - Trecho médio do rio Iguatemi-MS e ocorrência de um cotovelo de drenagem.Org: Aguiar (2009).--- 108

Figura 40: Perfil longitudinal do canal principal da bacia hidrográfica do rio Iguatemi - MS.

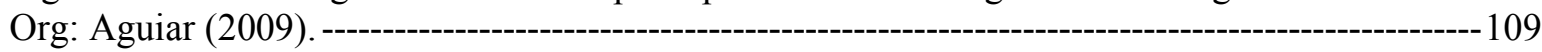

Figura 41: Perfil longitudinal do canal principal da bacia hidrográfica do rio Piquiri - PR

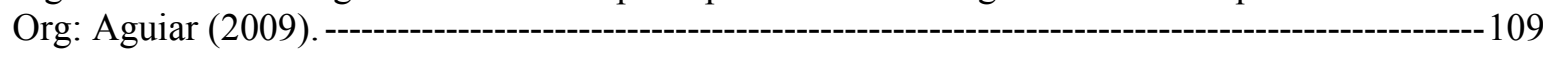

Figura 42: Curvas hipsográficas e de volume em termos relativos. ---------------------------------------111

Figura 43: Curvas hipsográficas e de volume em termos percentuais.------------------------------------111

Figura 44 : Distribuição dos valores de produção específica de sedimentos em suspensão (Pss) máximo (Max); mínimo (Min); mediana (Méd), quartil 1 (q1), quartil 3 (q3), do período 2002-2006,

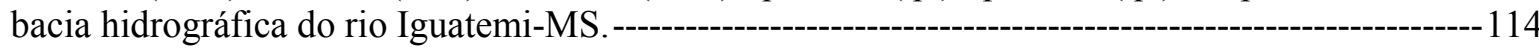

Figura 45: Distribuição dos valores de produção específica de sedimentos em suspensão Pss máximo (Max); mínimo (Min); mediana (Méd), quartil 1 (q1), quartil 3 (q3), do período 2002-2006, bacia hidrográfica do rio -PR. --o- 114

Figura 46: Gráficos das médias diárias de Pss das bacias hidrográficas analisadas. -------------------116

Figura 47: Correlações das variáveis hidrossedimentológicas. ----------------------------------------------- 117

Figura 48: Comparação das médias anuais das concentrações de sedimentos em suspensão das estações de monitoramento Estrada Iguatemi e Balsa Santa Maria no período 2002-2006. --------- 119

Figura 49: Imagem capturada pelo satélite QuickBird em 28/01/2004. Fonte: Digital Globe. Org: Aguiar (2009) -- 121

Figura 50: Médias diárias das precipitações das estações de monitoramento Estrada Iguatemi e

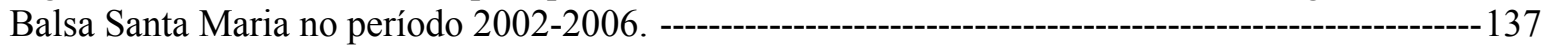

Figura 51: Médias diárias do nível fluviométrico das estações de monitoramento Estrada Iguatemi e Balsa Santa Maria no período 2002-2006. ---

Figura 52: Médias diárias da descarga líquida das estações de monitoramento Estrada Iguatemi e

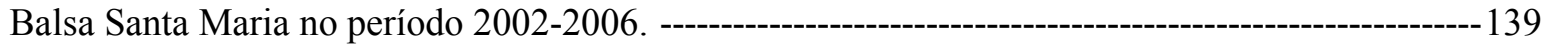

Figura 53: Médias diárias de descarga sólida de sedimentos nas estações de monitoramento Estrada Iguatemi e Balsa Santa Maria no período 2002-2006. -----140

Figura 54: Médias diárias da produção específica de sedimentos em suspensão nas estações de monitoramento Estrada Iguatemi e Balsa Santa Maria no período 2002-2006. ---------------141 


\section{LISTA DE TABELAS}

Tabela 1: Porcentagens das classes de declividade e tipos de relevo de acordo com Embrapa (1995).

Tabela 2: Porcentagens das classes de declividade e tipos de relevo da bacia hidrográfica do rio Iguatemi - MS.

Tabela 3 Porcentagens das classes de declividade e tipos de relevo da bacia hidrográfica do rio Piquiri - PR.

Tabela 4 - Relação dos comprimentos (Rlm), relação de bifurcação $(\mathrm{Rb})$ e relação entre $\mathrm{R} / \mathrm{m} / \mathrm{Rb}$ das ordens de canais da rede de drenagem da bacia hidrográfica do rio Iguatemi - MS.-----------102

Tabela 5 - Relação dos comprimentos (Rlm), relação de bifurcação $(\mathrm{Rb})$ e relação entre $\mathrm{R} 1 \mathrm{~m} / \mathrm{Rb}$ das ordens de canais da rede de drenagem da bacia hidrográfica do rio Piquiri - PR ---------------102

Tabela 6: Relação hierarquia, área média e relação entre áreas médias das áreas de drenagem direta por ordem de canal da bacia hidrográfica do rio Iguatemi, MS.

Tabela 7: Relação hierarquia, área média e relação entre áreas médias das áreas de drenagem direta por ordem de canal da bacia hidrográfica do rio Piquiri, PR. $-104$

Tabela 8: Análises morfométricas comparativas de parâmetros lineares das bacias hidrográficas Iguatemi e Piquiri. $-106$

Tabela 9: Análises morfométricas comparativas de parâmetros areais das bacias hidrográficas Iguatemi e Piquiri. $-106$

Tabela 10: Análises hipsométricas comparativas de parâmetros das bacias hidrográficas Iguatemi e Piquiri. $-107$

Tabela 11: Comparação dos valores médios mensais de Css no período 2002 -2006 nas estações de monitoramento das bacias hidrográficas analisadas. $-118$

Tabela 12: Elementos para obtenção da curva hipsográfica e de volume da bacia do rio Iguatemi 134

Tabela 13: Elementos para obtenção da curva hipsográfica e de volume da bacia do rio Piquiri. - 135

Tabela 14: Médias mensais dos parâmetros hidrossedimentológicos do período 2002-2006 das estações referentes as bacias hidrográficas analisadas. $-142$

Tabela 15: Médias mensais dos parâmetros hidrossedimentológicos do período 2002-2006 das estações referentes as bacias hidrográficas analisadas. $-142$ 


\section{LISTA DE QUADROS}

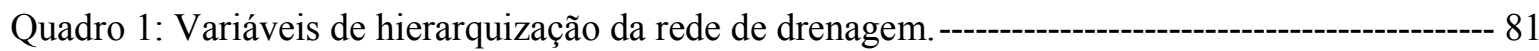

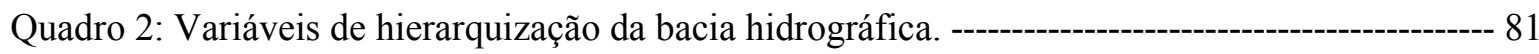

Quadro 3: Variáveis da análise linear da rede drenagem. --------------------------------------------------- 83

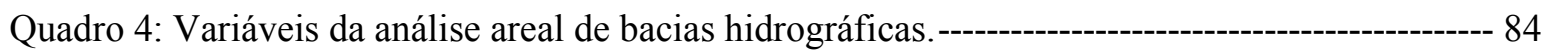

Quadro 5: Variáveis da análise hipsométrica de bacias hidrográficas.-------------------------------------- 84

Quadro 6: Análise comparativa de parâmetros hidrossedimentológicos das estações de monitoramento Estrada do Iguatemi e Balsa Santa Maria. --- 


\section{LISTA DE SÍMBOLOS}

A área de drenagem da bacia

Alt.min altitude mínima da bacia

Alt.max altitude máxima da bacia

E altitude média - elevação média da bacia

$\mathrm{Hm}$ amplitude topográfica da bacia

Kc coeficiente de compacidade

$\mathrm{r}^{2} \quad$ coeficiente de determinação

$\mathrm{Cm}$ coeficiente de manutenção dos canais

$\mathrm{Lu}$ comprimento médio dos canais

$\mathrm{Lb}$ comprimento da bacia

Lt comprimento total dos canais

Lp comprimento do rio principal

Dd densidade de drenagem

Eps extensão média do escoamento superficial

$\mathrm{Kf}$ fator de forma

Gcp gradiente do canal principal

$\mathrm{Rb}$ relação de bifurcação

Ir índice de rugosidade

$\mathrm{Nu}$ número de canais

$\mathrm{Nu}$ número de canais de cada ordem

$\mathrm{P} \quad$ perímetro da bacia

Rlm relação dos comprimentos médios

Rlb relação entre o Rlm e o Rb

$\mathrm{Rr}$ relação de relevo

Q descarga líquida

Css concentração de sedimentos em suspensão

Qss descarga sólida de sedimentos em suspensão

Pss produção específica de sedimentos em suspensão

$\mathrm{N}$ nível fluviométrico 


\section{RESUMO}

AGUIAR, A.M. Análises hidrogeomorfológicas e hidrossedimentológicas para comparação de duas bacias hidrográficas contribuintes do reservatório de Itaipu. 2009.157 f. Dissertação de Mestrado - Departamento de Geografia, Universidade de São Paulo, São Paulo 2009.

Neste estudo, o objetivo foi realizar análises hidrogeomorfológicas e hidrossedimentológicas para comparar duas bacias hidrográficas contribuintes do reservatório de Itaipu, ou seja, foram analisadas as bacias hidrográficas dos rios Iguatemi MS e Piquiri - PR. As análises hidrogeomorfológicas das bacias hidrográficas visaram identificar o potencial para geração, mobilização e estocagem de sedimentos em suspensão. As análises hidrossedimentológicas permitiram estimar a produção especifica de sedimentos em suspensão diária (Pss - ton $/ \mathrm{km}^{2} / \mathrm{dia}$ ) e com isto, foi possível complementar as análises hidrogeomorfológicas para verificar as contribuições das bacias hidrográficas no aporte de sedimentos em suspensão em direção ao ambiente aquático do reservatório de Itaipu. O uso de imagem multiespectral coletada pelo satélite QuickBird permitiu representar espacialmente o fluxo de sedimentos em suspensão provenientes das bacias hidrográficas nas áreas de suas desembocaduras, e avaliar por meio da interpretação visual as diferentes colorações da água na área de confluência com o rio Paraná. Foi constatado na data de passagem do satélite que na bacia hidrográfica do rio Iguatemi a Pss foi em média 4 vezes superior em relação a Pss da bacia hidrográfica do rio Piquiri, mesmo tendo a bacia hidrográfica do rio Iguatemi área de drenagem e descarga líquida menor quando comparada com a bacia hidrográfica do rio Piquiri. De acordo com as análises hidrogeomorfológicas e hidrossedimentológicas atualmente a bacia hidrográfica do rio Iguatemi apresenta-se mais sujeita aos processos erosivos quando comparada com a bacia hidrográfica do rio Piquiri. Sendo assim, são necessários estudos contínuos destes sistemas fluviais, e o desenvolvimento deste estudo pode ser utilizado no intuito de fornecer subsídios a novas pesquisas, além de novas informações pertinentes aos programas de preservação do meioambiente realizados pela Itaipu Binacional, sobretudo, a gestão dos recursos hídricos sob a ótica da bacia hidrográfica.

Palavras-chave: Análises hidrogeomorfológicas, Análises hidrossedimentológicas, Bacias hidrográficas, Produção específica de sedimentos em suspensão, Sensoriamento Remoto. 


\section{ABSTRACT}

AGUIAR, A.M. Hidrogeomorphologic and hidrosedimentologic analyses to compare two watersheds of Itaipu reservoir. 2009.157 f. Dissertação de Mestrado - Departamento de Geografia, Universidade de São Paulo, São Paulo 2009.

The aim of this research was to perform hidrogeomorphologic and hidrosedimentologic analyses and comparing two watersheds that drain into the reservoir Itaipu: Iguatemi-MS and Piquiri-PR. The hidrogeomorphologic analyses of the watersheds comprised evaluations of the potential sediment load yield through selected morfometric parameters. The hidrosedimentologic analyses emphasized evaluations of the specific sediment load yield (ton $/ \mathrm{km}^{2} /$ day) and hidrogeomorphologic analyses to verify sediment load carried into to the aquatic habitat of the Itaipu reservoir.The preliminary results indicated that Pss in Iguatemi river watershed was on average 4 times above Pss of Piquiri river watershed, when satellite Quickbird collected multispectral high-spatial-resolution remote sensing imagery on the rivers mouths. According to the hidrogeomorphologic and hidrosedimentologic analyses the Iguatemi river watershed has currently more potencial to develop erosion processes than Piquiri river watershed. Therefore, monitoring studies should be develop for these river systems in order to identifie the mean reasons and variables for that tendence. This study provide support to new researchs and to the conservation of the environment system the resevoir Itaipu.

KEY-WORDS: Hidrogeomorphologic analyses, Hidrosedimentologics analyses, Whatersheds, Specific sediment load yield, Remote Sensing. 


\section{INTRODUÇÃO}

Fundamental para a manutenção da biodiversidade, dos ciclos naturais, produção de alimentos e preservação da própria vida, os rios cada vez mais em nossa história representa um recurso estratégico e muito importante para a humanidade. Sua importância vem desde a época das antigas civilizações que se estabeleceram em sociedade ao longo dos rios Nilo, Indus, Amarelo (Huangho-Ho) e Eufrates. No século V a.c, o historiador grego Heródoto já dizia que "o Egito é uma dádiva do Nilo", uma vez que a civilização egípcia era dependente do ciclo do rio para o praticar a agricultura em uma área de deserto.

Nos períodos de cheias o rio Nilo transportava uma grande quantidade de sedimentos que eram distribuídos aos arredores de suas margens e, quando as águas recuavam na época das vazantes, o rio deixava no solo uma enorme quantidade de sedimentos e nutrientes importantes para fertilização dos solos. A partir desse processo natural a população pôde desenvolver o cultivo de cereais e garantir o suplemento de sua dieta alimentar. De fato, se os rios representam um importante papel na história de desenvolvimento das sociedades, somente na era moderna as intervenções antrópicas nos sistemas fluviais têm sido profunda e suficiente para desencadear expressivas modificações em um curto período de tempo de forma a comprometer os múltiplos usos da água.

Em relação à disponibilidade de recursos hídricos, o Brasil possui uma posição privilegiada quando comparada a de outros paises do mundo. A disponibilidade de água em abundância fornece parte importante para seu crescimento principalmente com a formação de grandes reservatórios para fins de abastecimento de água, regularização de cursos, obtenção de energia elétrica, irrigação, navegação, recreação entre outros usos. No entanto, toda esta vantagem confere-lhe a responsabilidade de gerenciar e promover as melhores práticas para uso, diagnóstico e preservação. Grande parte dessas alterações é prejudicial aos objetivos de conservação da diversidade ambiental, mas benéfica em relação a aspectos econômicos. Por exemplo, para atender a demanda de energia elétrica em função do 
crescimento industrial, do processo intensivo da urbanização, da expansão da fronteira e produção agrícola, dentre outros.

Existem diretrizes no Brasil para preservar e melhorar a qualidade dos recursos hídricos e seus usos múltiplos: trata-se de um conjunto de ações e recomendações descritas na Agenda 21 brasileira (2000). Neste documento a unidade espacial básica para aplicação da Política Nacional de Recursos Hídricos (PNRH) e atuação do Sistema de Nacional de Gerenciamento de Recursos Hídricos (SNGRH) é a bacia hidrográfica, conforme preconiza a lei 9.433 de $08 / 01 / 97$. Além disto, dentro do contexto dos investimentos realizados pela Agencia Nacional de Águas (ANA), a adoção da bacia hidrográfica com unidade espacial, tem como objetivo geral a construção de uma base de dados topologicamente consistente, adequada ao apoio da consolidação do SNGRH, não só para sua implantação, mas também para o seu gerenciamento futuro. Isto revela a importância da bacia hidrográfica como unidade espacial de síntese dos elementos geográficos, tanto os de origem antrópicas como os naturais.

Neste estudo são apresentados os resultados das comparações de análises hidrogeomorfológicas e hidrossedimentológicas das bacias hidrográficas do rios Iguatemi MS e Piquiri - PR. As análises hidrogeomorfológicas das bacias foram realizadas a partir da avaliação de variáveis morfométricas selecionadas da rede de drenagem e do relevo, permitindo a comparação. Em relação à comparação dos resultados das análises hidrossedimentológicas foram avaliadas a produção especifica diária de sedimentos em suspensão (Pss) das bacias hidrográficas, entre os anos de 2002 a 2006. Referente a este período foi utilizado uma imagem de satélite multiespectral proveniente do satélite QuickBird, com mesma data de passagem sob as desembocaduras dos rios Iguatemi e Piquiri. Com isto o sensoriamento remoto foi aplicado no intuito de identificar e representar espacialmente a intensidade do fluxo de sedimentos em suspensão.Por 
Foram adotados para desenvolvimento da pesquisa referenciais teóricometodológicos das áreas da geomorfologia fluvial, geoprocessamento, sensoriamento remoto e hidrossedimentologia. 


\section{OBJETIVOS}

\subsection{Objetivo Central}

A pesquisa visou efetuar análises hidrogeomorfológicas e hidrossedimentológicas para comparação de duas bacias hidrográficas afluentes do rio Paraná, no que diz respeito as suas prováveis influências no aporte de sedimentos em suspensão em direção ao reservatório da UHE Itaipu Binacional.

Para alcançar seu objetivo, a pesquisa contou com a utilização de insumos coletados por meio de radar interferométrico da missão SRTM (Shuttle Radar Topography Mission) e dados do monitoramento hidrossedimentométrico disponibilizados pelo setor de meio ambiente da Itaipu Binacional, além da utilização de softwares de geoprocessamento, estatística e processamento digital de imagens (PDI).

\subsection{Objetivos Específicos}

Dentre os objetivos secundários que viabilizam as análises pretendidas, têm se:

- Processar por meio do software Erdas Imagine 9.1, as imagens de radar da missão SRTM para geração de modelos digitais de elevação com resolução espacial de 30m e compatível a escala cartográfica de 1:250.000;

- Extrair automaticamente a rede de drenagem, os limites das bacias hidrográficas e hierarquizar os resultados por meio de procedimentos específicos dos softwares ArcGis 9.2 e Hidroflow 0.9;

- Realizar levantamento e análise de variáveis morfométricas lineares, areais e hipsográficas; 
- Compartimentar os canais principais das bacias hidrográficas em diferentes segmentos representativos quanto à ocorrência de rupturas de declive;

- Gerar e analisar perfis longitudinais dos canais principais

- Gerar e analisar curvas hipsográficas e de volume das bacias;

- Tratar os dados provenientes do monitoramento hidrológico e sedimentológico;

- Calcular a descarga sólida em suspensão (Qss) e produção especifica de sedimentos em suspensão (Pss) e comparar as áreas de confluência dos rios Iguatemi e Piquiri com o rio Paraná por meio do sensoriamento remoto, tendo como suporte imagem de satélite com data de passagem próxima a data da coleta dos parâmetros hidrossedimentológicos.

- Gerar gráficos de analises comparativas das variáveis geomorfológicas e hidrossedimentológicas;

- Expor a importância de análises geomorfológicas e hidrossedimentológicas de bacias hidrográficas, para caracterização do aporte de sedimentos em suspensão no reservatório de Itaipu;

- Contribuir para comunidade cientifica e Itaipu Binacional, com os procedimentos voltados ao estudo dinâmico de bacias hidrográficas;

- Propor hipóteses sobre as variáveis mais significativas na geração de sedimentos em suspensão que explicam as diferenças encontradas por meio de comparação das duas bacias hidrográficas estudadas. 


\section{CARACTERIZAÇÃO DA ÁREA DE ESTUDO}

Do ponto de vista regional, a área de estudo localiza-se na fronteira entre o Brasil, Paraguai e os Estados do Mato Grosso do Sul e Paraná, à montante do reservatório de Itaipu entre as latitudes $23^{\circ} 00^{\prime} 00^{\prime \prime} \mathrm{S}-25^{\circ} 30^{\prime} 00^{\prime \prime} \mathrm{S}$, e longitudes $52^{\circ} 00^{\prime} 00^{\prime \prime} \mathrm{W} 55^{\circ} 30^{\prime} 00^{\prime \prime}$ W (Figura 1).

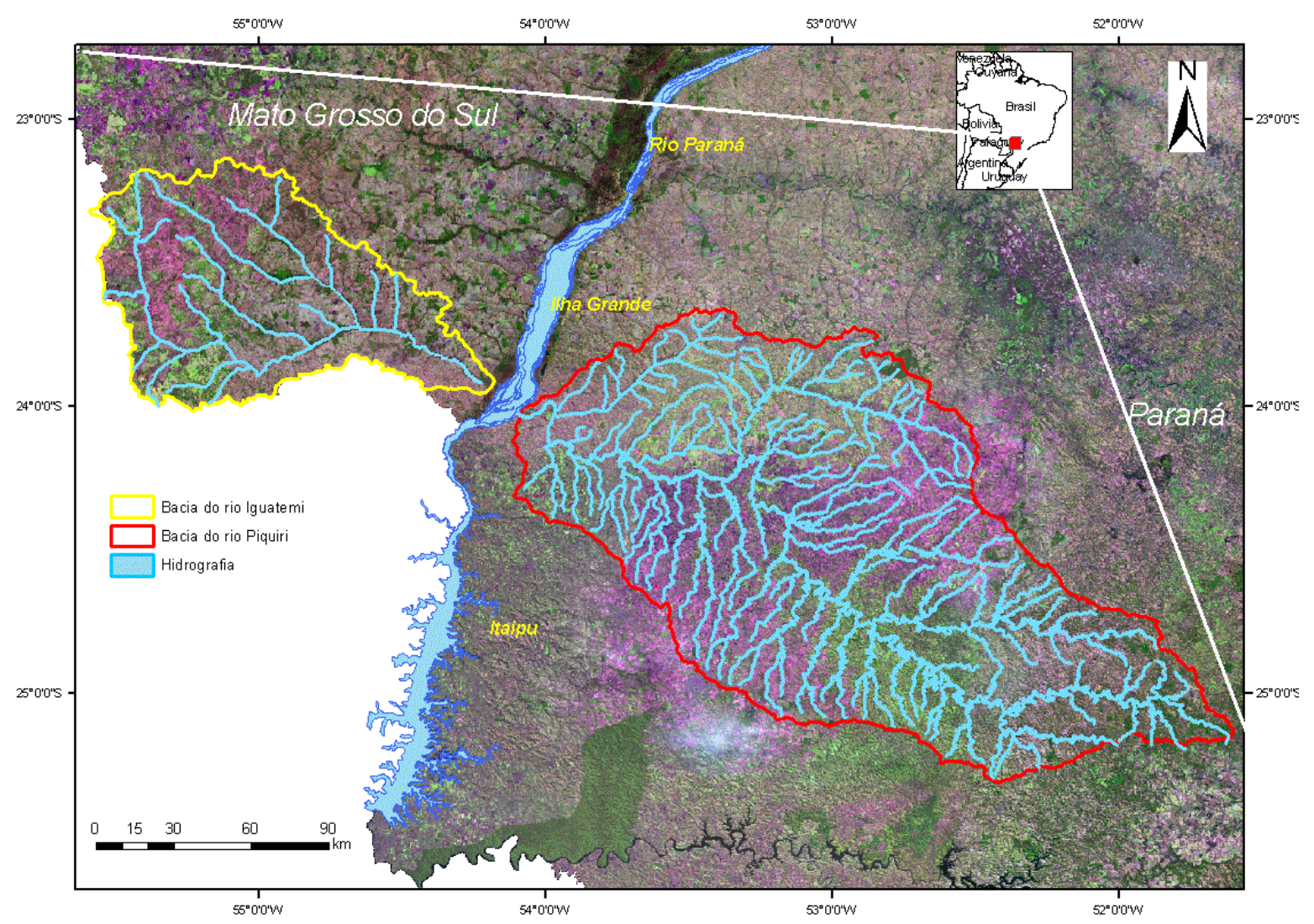

Figura 1: Localização da área de estudo. Fonte: Mosaico de Imagens Landsat TM 5 e Hidro Web ANA (Agência Nacional de Águas). Org. Aguiar (2009).

As bacias hidrográficas selecionadas são subsistemas sem barragens de grande porte, localizados à jusante de uma série de grandes barragens implantadas ao longo dos rios Paraná, Paranapanema e Tietê, as quais formam grandes reservatórios. Estes reservatórios atuam como áreas de retenção de matéria orgânica e inorgânica transportadas 
pela da ação de fluxos de energia de origem fluviais, eólica e pluvial, isto nos mostra que as bacias selecionadas apresentam uma influência direta no sistema fluvial do rio Paraná e consequentemente ao reservatório de Itaipu. As barragens construídas nos principais rios da bacia do Paraná caracterizam-se como um sistema de reservatórios em cascata em função de nova localização de rupturas topográficas nos perfis longitudinais dos canais fluviais afetados (Figura 2).

\section{SISTEMA DE RESERVATÓRIOS EM CASCATA}

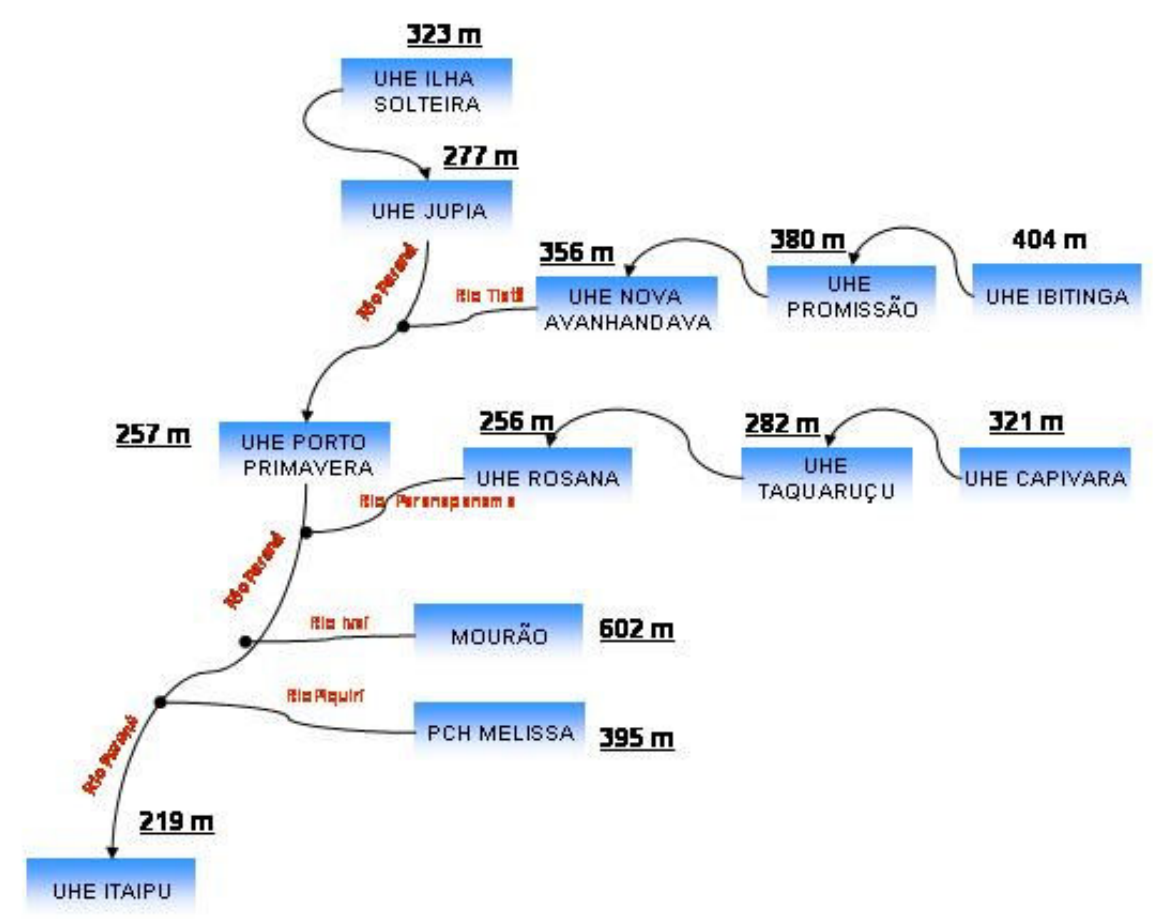

Figura 2: Sistema em cascata dos reservatórios dos rios Paraná, Paranapanema e Tietê, Org:Aguiar (2009).

A UHE de Itaipu destaca-se como um dos maiores empreendimentos de engenharia construída em consórcio entre o Brasil e Paraguai, a área superficial do reservatório é de $1.350 \mathrm{~km}^{2}$ estende-se desde Foz do Iguaçu-PR até Guaíra-PR, com aproximadamente 
$170 \mathrm{~km}$ de comprimento. A maior parte dos 29 bilhões de metros cúbicos de água represada no reservatório é renovada em média a cada 32 dias (ITAIPU 2000).

Com o fechamento das comportas da barragem, o nivelamento das águas do reservatório de Itaipu gerou expressivas mudanças espaciais no rio Paraná e áreas adjacentes do sistema fluvial. Essa mudanças, destaca-se a submersão dos "Saltos del Guaira" (Sete Quedas). Segundo Andrade (1942), o primeiro nome recebido pelas quedas foi o de Santa Vitória, dado pelo nobre espanhol D. Luís de Céspedes Xeria, capitãogeneral do Paraguai em 1628 em homenagem à sobrinha de Martin Sá. Entretanto essa denominação não vingou e o que vigora até hoje, é a denominação dada por bandeirantes anônimos. Essa denominação "Sete Quedas", apesar de errada não trata somente de sete saltos ou quedas, mas no total dezoito espalhados em uma vasta extensão (Figura 3). 


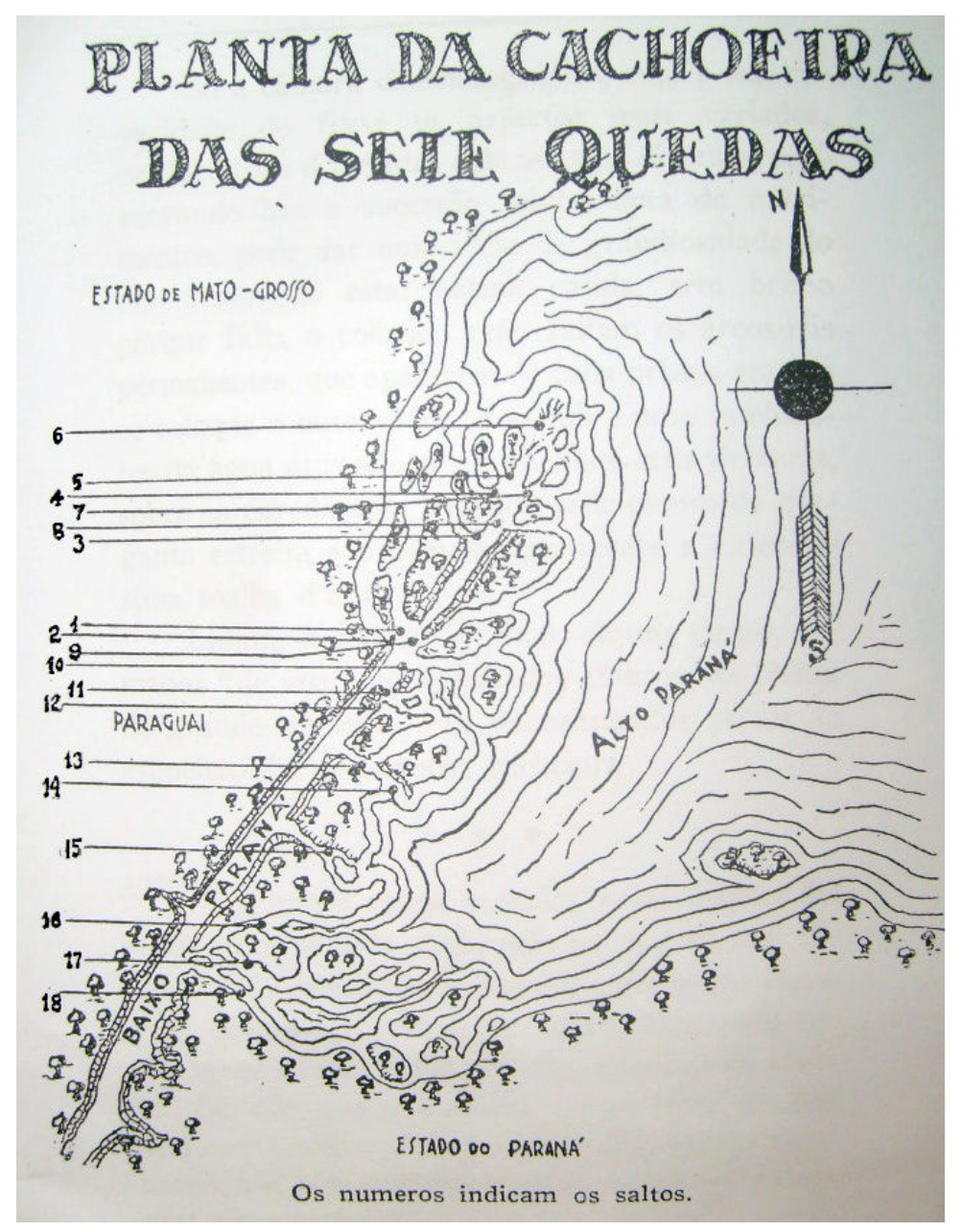

Figura 3: Distribuição espacial das dezoito quedas dos "Saltos del Guaíra”. Fonte: Andrade (1942).

$\mathrm{Na}$ área de ocorrência das quedas de água, ou, "Sete Quedas”, o rio Paraná fluía num cânion de $5 \mathrm{~km}$ de comprimento e $60 \mathrm{~m}$ de largura, importante barreira geográfica com mais de $120 \mathrm{~m}$ de desnível. Este desnível está fortemente relacionado aos falhamentos dos derrames basálticos que houve na região de ocorrência das quedas de água (Figuras 4; 5). 


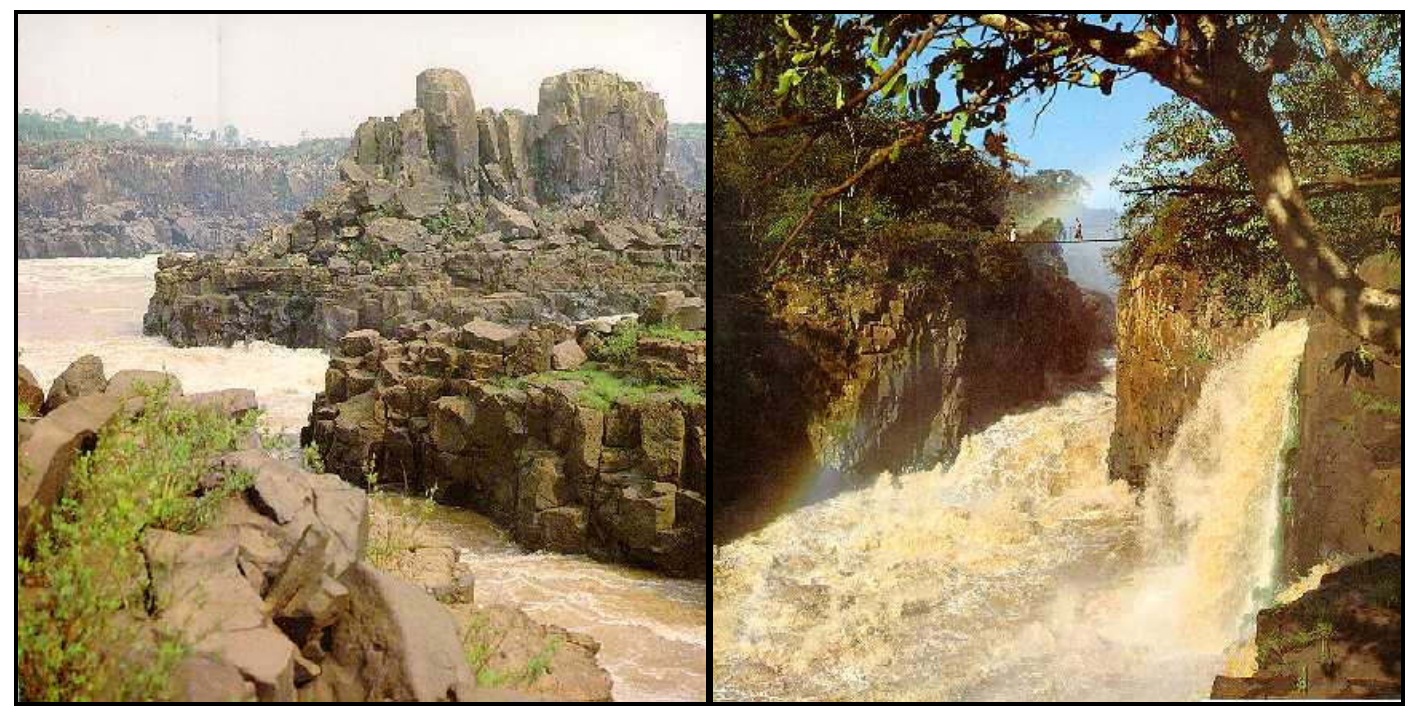

Figura 4: Feições geomorfológicas atualmente submersas no rio Paraná. Fonte: Prefeitura Municipal de Guaíra, PR.

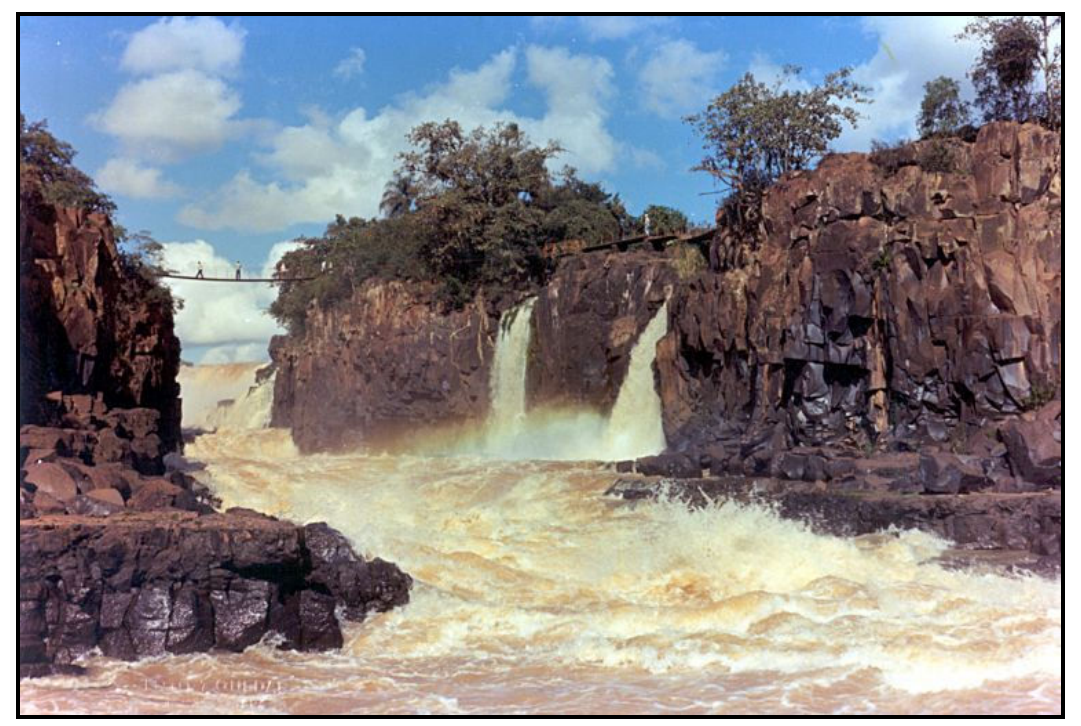

Figura 5: Cânion originado por falhamentos dos derrames rochosos. Fonte: Prefeitura Municipal de Guaíra, PR.

$\mathrm{Na}$ época do enchimento do reservatório de Itaipu a "Sete Quedas" eram consideradas uma das maiores quedas de água do mundo em termos de volume de água. Antes da formação do reservatório a área era um importante patrimônio natural que atraía muitos turistas ao local. Atualmente, próximo a Guaíra-PR e Mundo Novo-MS, as quedas 
de água encontram-se submersas e em seu lugar é possível visualizar a Ponte Ayrton Senna com $3.607 \mathrm{~m}$ de comprimento e $10 \mathrm{~m}$ de largura (Figura 6).

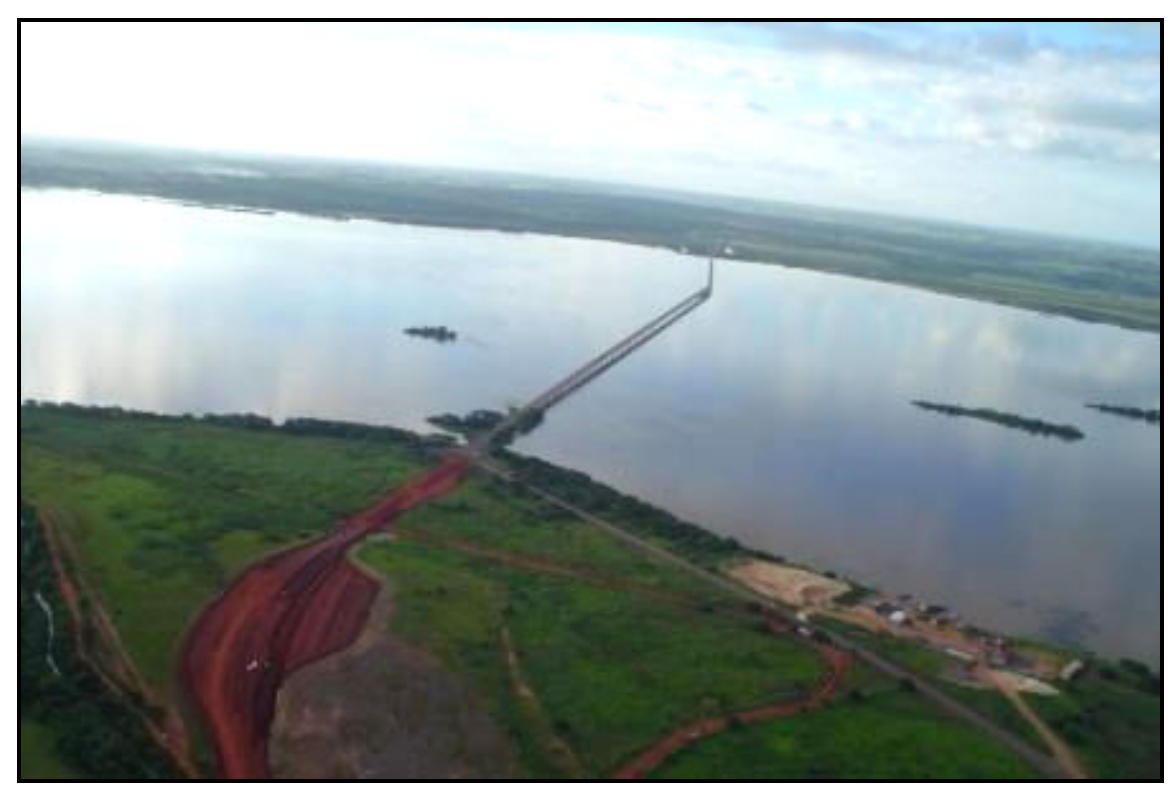

Figura 6: Ponte Ayrton Senna - Guaíra PR, área dos submersos "Saltos del Guaíra". Fonte: Fantucci (2008).

O reservatório possui 66 pequenas ilhas, das quais 44 estão na margem brasileira e 22 na paraguaia. Os rios Iguatemi e Piquiri são afluentes do rio Paraná, localizados na sua margem direita e esquerda respectivamente. Nas bacias hidrográficas dos rios Iguatemi e Piquiri estão inseridos 79 municípios que ocupam uma área total de $32.356 \mathrm{~km}^{2}$. Estes municípios também representam destaque regional em função do uso e ocupação do solo para fins agrícolas. Em relação aos aspectos geológicos a área de estudo está inserida na unidade morfo-estrutural bacia sedimentar do Paraná, caracterizada com uma bacia intracratônica que evoluiu sobre a Plataforma Sul-Americana à cerca de 400 milhões de anos, que em seu conjunto apresenta uma sucessão de terrenos sedimentares e vulcânicos, com idades desde o Período Devoniano (MINEROPAR 2003).

Quanto à distribuição espacial dos solos a bacia apresenta uma grande variabilidade de formações, sendo que nos terrenos de basalto prevalecem os Latossolos vermelhos- 
argilosos e nos terrenos sedimentares, prevalecem os Latossolos vermelho-amareloarenosos. As formas de relevo e as litologias são muito diferenciadas. Pode se afirmar que nas partes centrais da bacia sedimentar, tanto em terrenos sedimentares de arenitos como nos de basalto, prevalecem colinas de topos convexo amplo e mediano. (ROSS 2006).

Em relação ao uso do solo suas áreas são ocupadas por extensas áreas de pastagem e agricultura tecnificada. A vegetação natural da bacia do Paraná foi bruscamente convertida em pastagens e grandes áreas de plantio agrícola, restando atualmente pequenos fragmentos de floresta secundária e corredores ao longo dos fundos de vales com floresta em estágio de regeneração média a inicial. A pecuária de cria e corte com melhoramentos genéticos, e o plantio tecnificado de monoculturas são aspectos socioeconômicos que cada vez mais afeta os sistemas naturais desta bacia. Entre as conseqüências do uso ocorre na bacia a erosão dos solos, diminuição da qualidade das águas, redução da flora e fauna, queimadas e desmatamento da vegetação natural (ROSS 2006).

Em termos espaciais, o principal rio da bacia é o rio Paraná que é o quarto maior em área de drenagem e o décimo maior rio do mundo em descarga liquida. De sua nascente no planalto central até a foz no rio da Prata percorre $4.695 \mathrm{~km}$. Em território brasileiro drena uma área de $891 \mathrm{~km}^{2}$ e em certas áreas o padrão de drenagem apresenta canais múltiplos, com grandes ilhas separando canais anastomosados. Estas ilhas são constituídas por depósitos tabulares argilosos e por lentes arenosas. Os canais são dominados por barras transversais e complexas e as formas de leito dominantes são as dunas subaquosas de grande porte (SOUZA FILHO; STEVAUX, 1997).

A configuração territorial do Brasil é marcada pela ocorrência de grandes bacias hidrográficas, as quais são responsáveis pelo fornecimento do potencial hidráulico para geração de energia elétrica a sociedade, além de outros usos múltiplos. Neste estudo as bacias hidrográficas analisadas enquadram-se como sub-bacias da bacia do rio Paraná, e têm como canais principais os rios Iguatemi e Piquiri, e juntamente com o segmento do alto 
rio Paraná formam um dos principais afluentes de contribuição da bacia de captação do reservatório de Itaipu.

Quanto ao aspecto histórico de ocupação humana e uso dos recursos hídricos, na década de 50 do século passado a bacia hidrográfica do rio Paraná foi o foco estratégico do governo brasileiro para o planejamento territorial e aproveitamento hidrelétrico do sistema fluvial. Este cenário político resultou em um dos maiores e mais complexos sistemas hidrelétricos do mundo, com destaque para a UHE Itaipu Binacional (ITAIPU 2000).

Fruto de um acordo bilateral entre o Brasil e Paraguai, a hidrelétrica de Itaipu teve como ponto de partida para sua implantação a assinatura da "Ata do Iguaçu” em 1966. O documento teve como objetivo principal a realização de estudos ao longo do rio Paraná para o aproveitamento dos recursos hídricos do sistema fluvial pertencentes aos dois paises. Anos após a "Ata de Iguaçu”, Brasil e Paraguai assinaram em 1973, o "Tratado de Itaipu", cujo principal objetivo reside no aproveitamento hidráulico do rio Paraná, com posterior gerenciamento, em sistema de condomínio entre as duas nações (ITAIPU 2006).

Em 1974 nascia Itaipu uma empresa de regime jurídico único no mundo, regida pelo próprio Tratado e pelas normas de Direito Internacional público. Em 1975 mais de 40 mil trabalhadores iniciam a construção da usina, a primeira unidade geradora entrou em operação no dia 24 de maio de 1984. As obras continuaram até 1991, com a montagem da $18^{\mathrm{a}}$ unidade geradora, sendo que finalmente, entre os anos de 2000 e 2006, mais duas unidades (U9A e U18A) foram instaladas e ativadas para que Itaipu pudesse operar com capacidade máxima.

O desenvolvimento desta pesquisa está relacionado a outras pesquisas já realizadas a respeito do aporte de sedimentos em suspensão no reservatório de Itaipu, como por exemplo, a participação desse autor em projetos de iniciação cientifica com objetivo de aplicação do sensoriamento remoto em sistemas fluviais (AGUIAR e GOMES 2006). Aguiar e Gomes desenvolveram uma análise de distribuição dos sedimentos em suspensão ao longo de um perfil longitudinal do reservatório de Itaipu ao correlacionar o comprimento 
do reservatório e a reflectância de superfície $\left(\mathrm{R}_{\lambda}\right)$ da lâmina da água, por meio de imagens multiespectrais do satélite CBERS 2 (Chinese-Brazilian Earth Resource Satélite -2), capturadas pelo sensor CCD (Couple Charged Device), no período de 24/03/2004 e 19/09/2004. Para o processamento digital das imagens (PDI), foi utilizado o software Spring 4.2 do Instituto Nacional de Pesquisas Espaciais (INPE). Os resultados destes estudos indicaram a ocorrência de elevados valores de $\mathrm{R}_{\lambda}$ na zona a montante da barragem de Itaipu, onde as águas dos rios Iguatemi, Paraná e Piquiri encontram-se em constantes processos de difusão. $\mathrm{O}$ comportamento espectral dos valores de $\mathrm{R}_{\lambda}$ apresentou uma diminuição gradual em direção à jusante da zona superior até a inferior próximo da barragem. Espacialmente, este comportamento significa a estratificação longitudinal do reservatório em zonas diferenciadas quanto à ocorrência da $R_{\lambda}$. Entretanto o comportamento dos valores de $\mathrm{R}_{\lambda}$ indica que no sistema aquático do reservatório é evidente a participação do rio Paraná e das bacias hidrográficas de seus afluentes no aporte de sedimentos em suspensão em direção do reservatório.

Pagioro (1999) constatou a ocorrência de valores de amostras da concentração de sedimentos em suspensão superiores a $10,0 \mathrm{mg} / 1$ na estação a montante da barragem de Itaipu, que decrescem para concentrações inferiores a 3,0 mg/l nas proximidades da barragem. Esta variabilidade indica que o reservatório retém sedimentos em suspensão provenientes dos processos erosivos próprios como também de sua bacia de contribuição. Outra questão correlacionada a ocorrência de sedimentos em suspensão diz respeito à disponibilidade de nutrientes primários, os quais, incluem o nitrogênio, fósforo, potássio, e nutrientes secundários como o cálcio, magnésio e enxofre presentes nos sedimentos.

A concentração de nutrientes tem papel fundamental sobre a produtividade primária do fitoplâncton. Alguns nutrientes podem ser de grande importância na produtividade primária de certos grupos de algas. O silicato, por exemplo, é o principal nutriente controlador da produtividade de diatomáceas. Muitas espécies de algas absorvem nutriente ativamente, isto acontece no início do período de estratificação quando ocorrem 
concentrações significativas de nutrientes no meio, possibilitando que populações de algas cresçam e se reproduzam mesmo após o esgotamento de nutrientes do meio. $\mathrm{O}$ aumento da quantidade de algas e posterior decomposição provocam o aumento da disponibilidade de matéria orgânica e de microorganismos, consequentemente a deterioração da qualidade da água (ESTEVES 1998). Os estudos realizados em Itaipu indicam que há na área a montante da barragem a ocorrência de intensos processos de contribuição de sedimentos em suspensão provenientes das áreas adjacentes ao reservatório de Itaipu. Possivelmente as intervenções antrópicas ocorrentes nas bacias hidrográficas das áreas contribuintes venham ser um dos processos mais significativos nas modificações do ambiente aquático do reservatório.

Segundo Thornton (1990), o sedimento não é somente o principal poluente da água por peso e volume, mas também o principal transportador e catalisador de partículas provenientes de defensivos agrícolas, resíduos orgânicos, nutrientes e organismos patogênicos. Na Figura 7, há o destaque das áreas de confluências dos rios Iguatemi, Piquiri e rio Paraná a montante da barragem de Itaipu nas proximidades de Ilha Grande e Guaíra PR, onde é possível constatar a diferença da cor da água, que variam em função da ocorrência de sedimentos em suspensão e outros constituintes. 


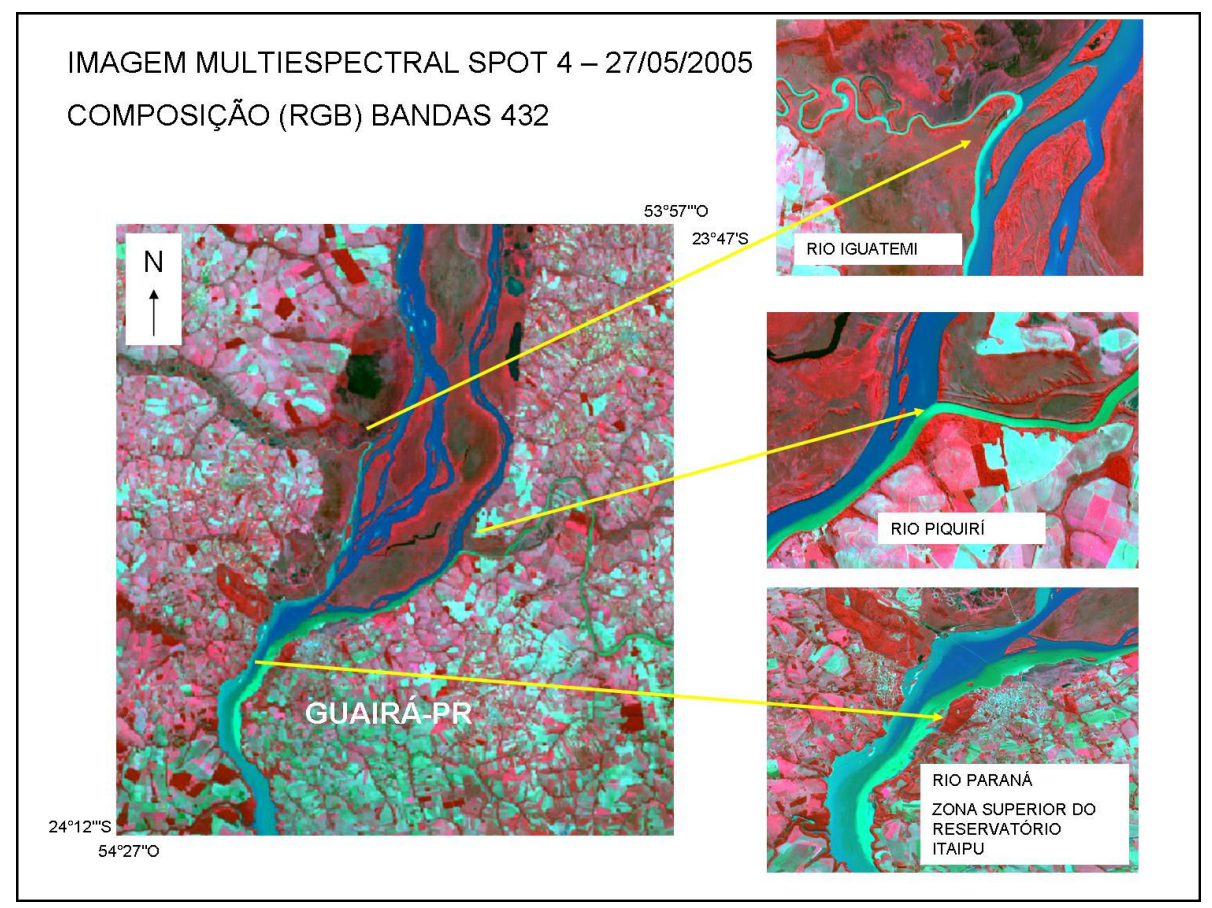

Figura 7. Áreas de confluências dos rios Iguatemi e Piquiri, com o Paraná a montante da barragem de Itaipu. Org: Aguiar (2009).

Nestas áreas os processos de mistura das águas indicam que a intensidade das interrelações dos elementos do sistema fluvial em questão pode desencadear uma significativa resposta de mudança no ambiente aquático do reservatório de Itaipu, por exemplo, o preenchimento do reservatório por sedimentos e aumento da disponibilidade de nutrientes diretamente ligados à situação trófica do ecossistema aquático. De acordo com Tundsi (1993), as influências das modificações hidrodinâmicas, operação do reservatório, intensidade e duração dos gradientes físicos e químicos (longitudinais e verticais) afetam a estrutura e dinâmica ecológica dos reservatórios.

Neste contexto, o desenvolvimento desta pesquisa visou fornecer subsídios aos programas de preservação do meio-ambiente realizados pela Itaipu Binacional, sobretudo, a gestão dos recursos hídricos sob a ótica da bacia hidrográfica. 


\subsection{Caracterização física da bacia hidrográfica do rio Iguatemi-MS}

A bacia hidrográfica do rio Iguatemi está localizada no extremo sul do Estado do Mato Grosso do Sul, na fronteira do Brasil e Paraguai, entre as latitudes $23^{\circ} 00^{\prime} 00^{\prime \prime} \mathrm{S}$ e

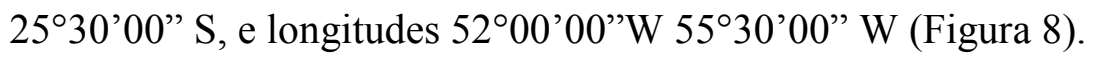

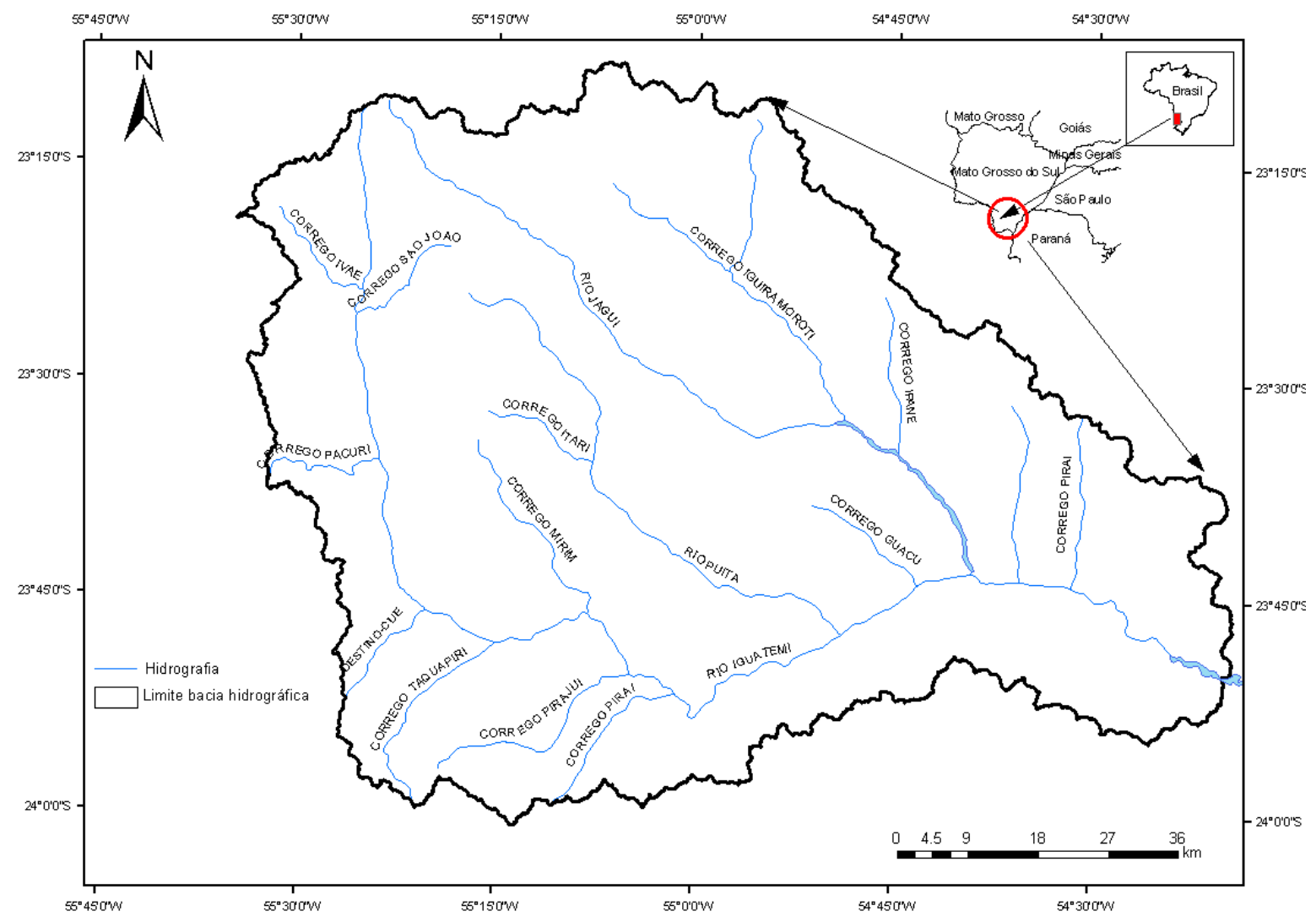

Figura 8: Bacia hidrográfica do rio Iguatemi - MS. Fonte:HidroWeb ANA.Org: Aguiar (2009).

$\mathrm{O}$ rio Iguatemi, principal tributário da bacia é afluente da margem direita do rio Paraná em um segmento onde o rio Paraná é multicanal em função da formação de grandes ilhas (Figura 9). 


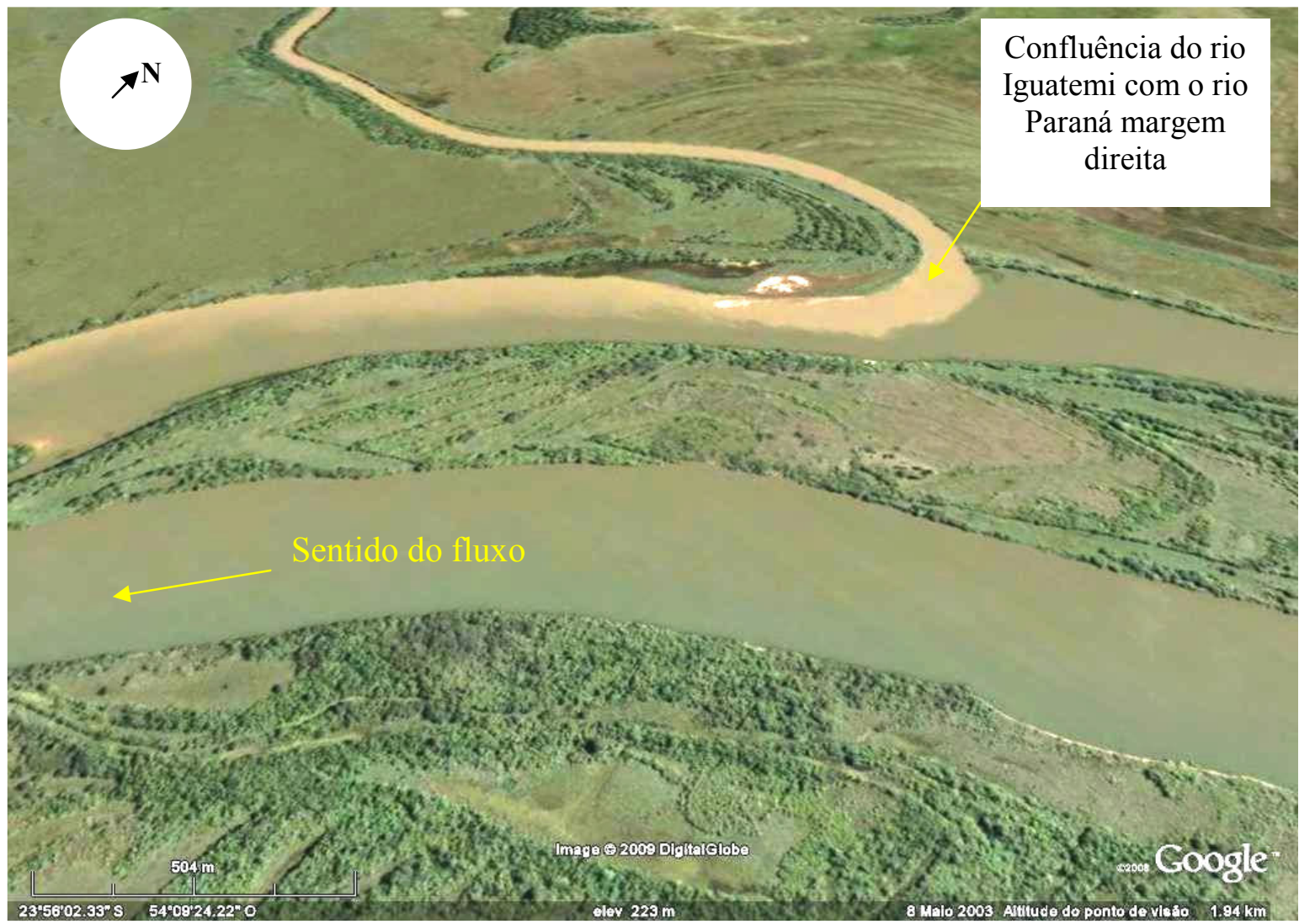

Figura 9: Localização da área de confluência do rio Iguatemi-MS com o rio Paraná. Fonte: Imagem Digital Globe, Org: Aguiar (2009).

O rio Iguatemi-MS deságua no rio Paraná a $226 \mathrm{~m}$ a cerca de $20 \mathrm{~km}$ a montante da ocorrência dos submersos "Saltos del Guaíra", que era uma importante barreira biogeográfica entre o alto e médio rio Paraná. A bacia do Iguatemi encontra-se em uma área de transição quanto às características do clima. De acordo com IBGE (1990), uma das características marcantes na região é o clima Tropical, com um a dois meses de seca, sendo a temperatura média anual de $20^{\circ} \mathrm{C}$ com precipitações maiores que $1.500 \mathrm{~mm} / \mathrm{ano}$. As chuvas são concentradas entre os meses de janeiro a abril atingindo os maiores valores nos meses de março e abril.

A agricultura e a pecuária são as principais atividades econômicas praticadas na bacia hidrográfica do rio Iguatemi-MS. No passado, houve intensa exploração de madeira, 
que anos mais tarde com a implantação da agropecuária ocorreu o desmatamento de extensas áreas de florestas da bacia, restando apenas fragmentos.

A bacia hidrográfica do rio Iguatemi-MS possui embasamento onde ocorrem litológicas pouco diferenciadas. Ocorrem na bacia as unidades da Formação Caiuá do Grupo Bauru e da Formação Serra Geral do Grupo São Bento (Figura 10).

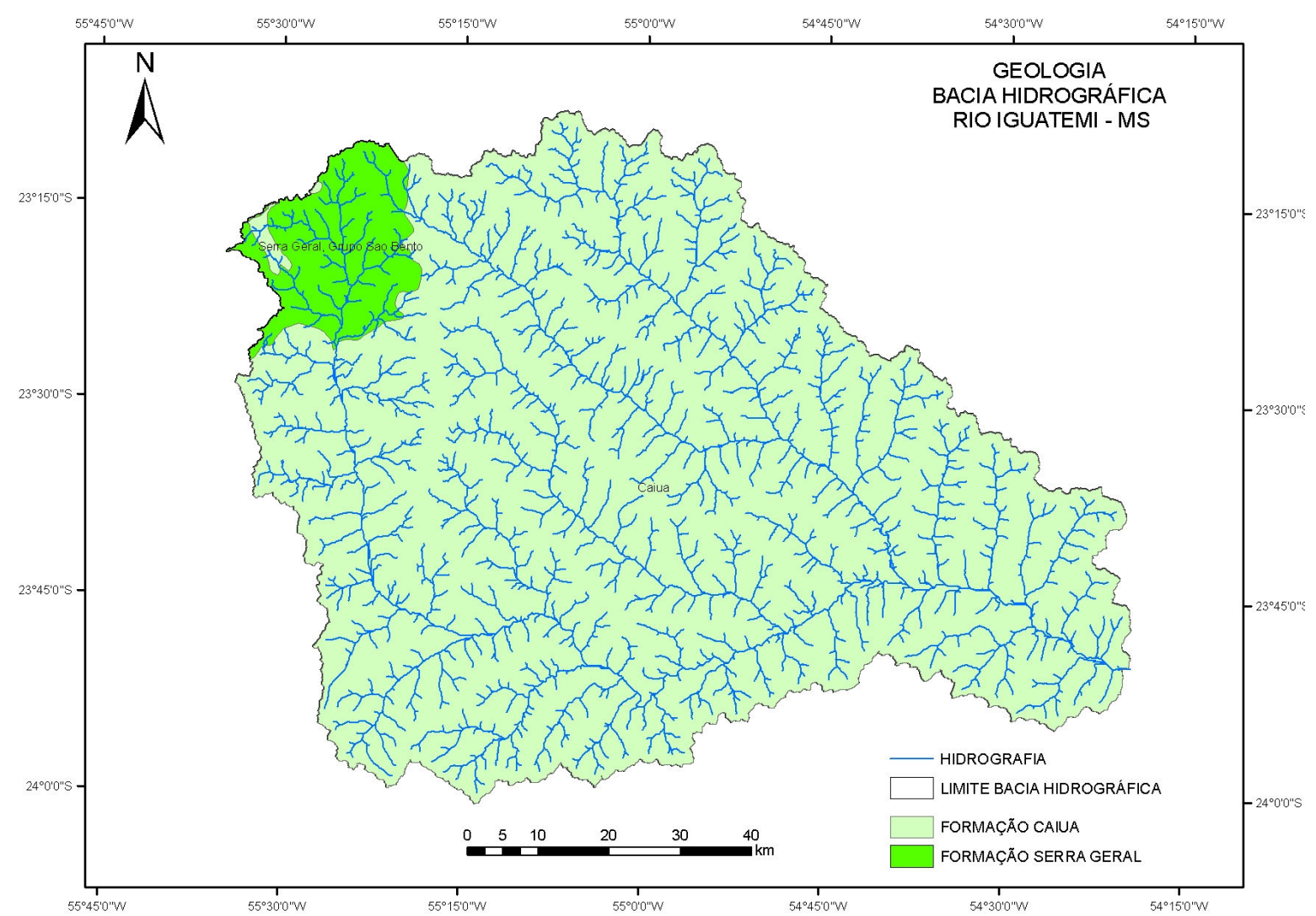

Figura 10: Geologia da bacia hidrográfica do rio Iguatemi-MS. Fonte: CPRM (2001). Org: Aguiar (2009).

Segundo Mezzalira (1981), foi Washburne (1930), quem descreveu formalmente a presença de arenitos de granulometria uniforme, com ausência de seixos ou camadas de argila e com peculiar estratificação cruzada na bacia do Paraná, aos quais se referiu como de origem eólica, denominando-os de Arenito Caiuá. Anos após a pesquisa de Washburne (1930) e Soares et al; (1980), referenciou a ocorrência desses arenitos na Formação Caiuá, 
como unidade litoestratigráfica formal do Grupo Bauru, e o reconhecimento de sua deposição em ambiente eólico.

Mineropar (2003) descreve a Formação Caiuá, constituída de arenitos finos a médios, róseos a avermelhados, com abundantes estratificações cruzadas. Esta formação ocorre em toda a região noroeste do Paraná, sul de Mato Grosso e oeste de São Paulo, com espessura chegando até $250 \mathrm{~m}$. Sua principal característica é ser extremamente friável, em decorrência da sua composição granulométrica argilo-arenosa, e extensas superfícies planas e onduladas, cobertas preferencialmente por vegetação rasteiras e gramíneas.

A bacia do Iguatemi está inserida na unidade morfo-estrutural bacia sedimentar do Paraná, sendo que a unidade geomorfológica principal é a denominada Planalto de Maracajú-Campo Grande. Ao longo do rio Iguatemi, ocorre áreas planas resultantes da acumulação fluvial em planície, periodicamente alagada. Também há formas erosivas como superfícies erosivas tabulares, provenientes de relevo residual de topos aplainado, provavelmente testemunhos de superfície aplainada. As principais formas de dissecação da bacia são as formas convexas e tabulares, folha SF-21 Campo Grande (RADAM, 1982). 


\subsection{Caracterização física da bacia hidrográfica do rio Piquiri -PR}

A bacia hidrográfica do rio Piquiri está inserida no extremo oeste do Estado do Paraná entre as latitudes $23^{\circ} 00^{\prime} 00^{\prime \prime} \mathrm{S}-25^{\circ} 30^{\prime} 00^{\prime \prime} \mathrm{S}$, e longitudes $52^{\circ} 00^{\prime} 00^{\prime \prime} \mathrm{S}$ 55³0’00”(Figura 11).

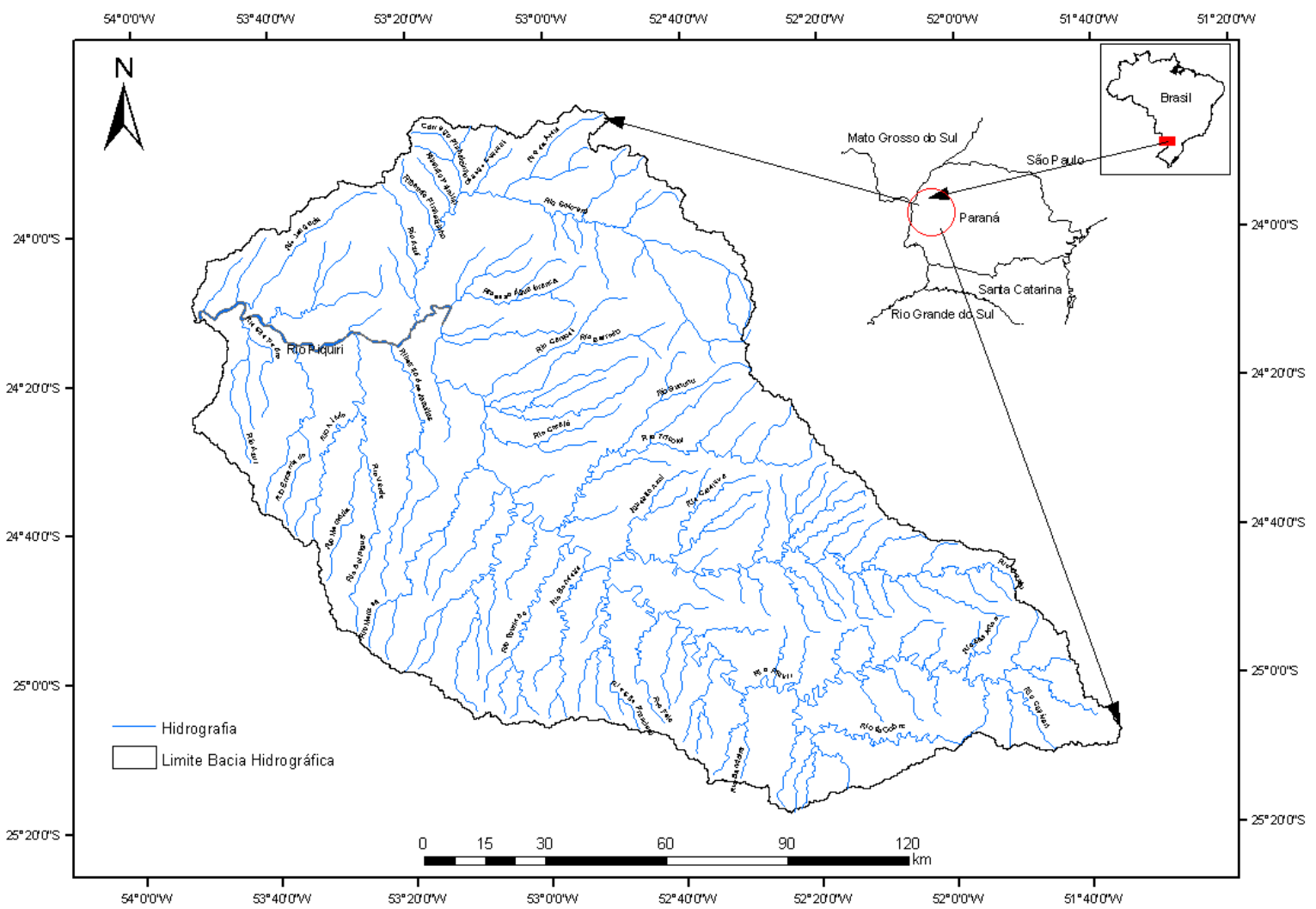

Figura 11: Localização da bacia hidrográfica do rio Piquiri-PR. Fonte: HidroWeb ANA. Org: Aguiar (2009).

O rio Piquiri é um afluente da margem esquerda do rio Paraná, cuja foz está localizada próximo da área de entorno de Ilha Grande. Na figura 12, observa-se a área de confluência com o rio Paraná, por meio de uma imagem coletada pelo satélite QuickBird em 28/02/2007 podemos ver a diferença da cor da água do rio Piquiri - PR e com a água do 
rio Paraná. Na Figura 13, podemos ver o canal do rio Piquiri e a cor da água que visualmente indica alta concentração de sedimentos em suspensão.

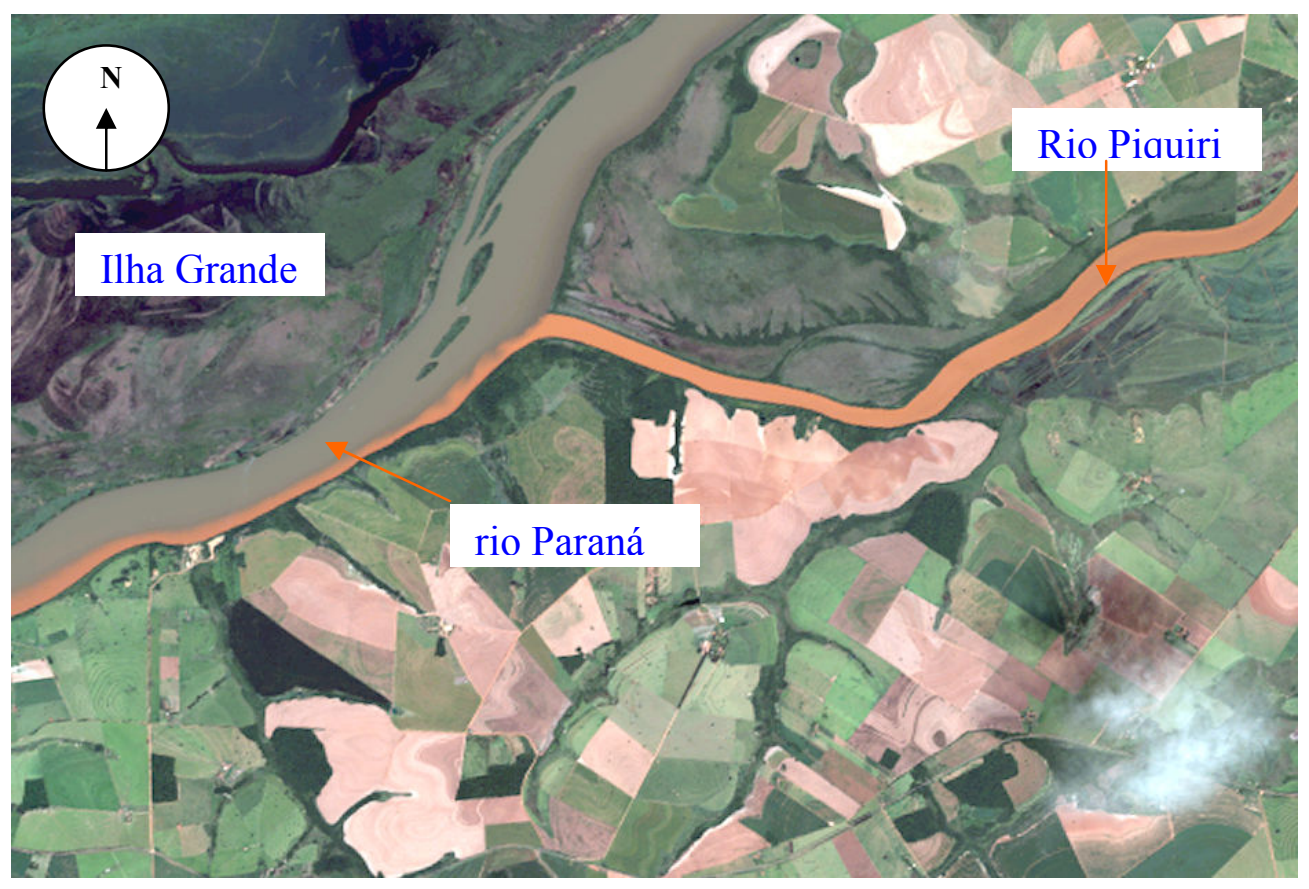

Figura 12: Localização da área de confluência do rio Piquiri - PR com o rio Paraná, Fonte: Digital Globe, "quick look" composição RGB (321) da imagem do satélite "Quick Bird" de 28/02/2007. Org: Aguiar (2009). 


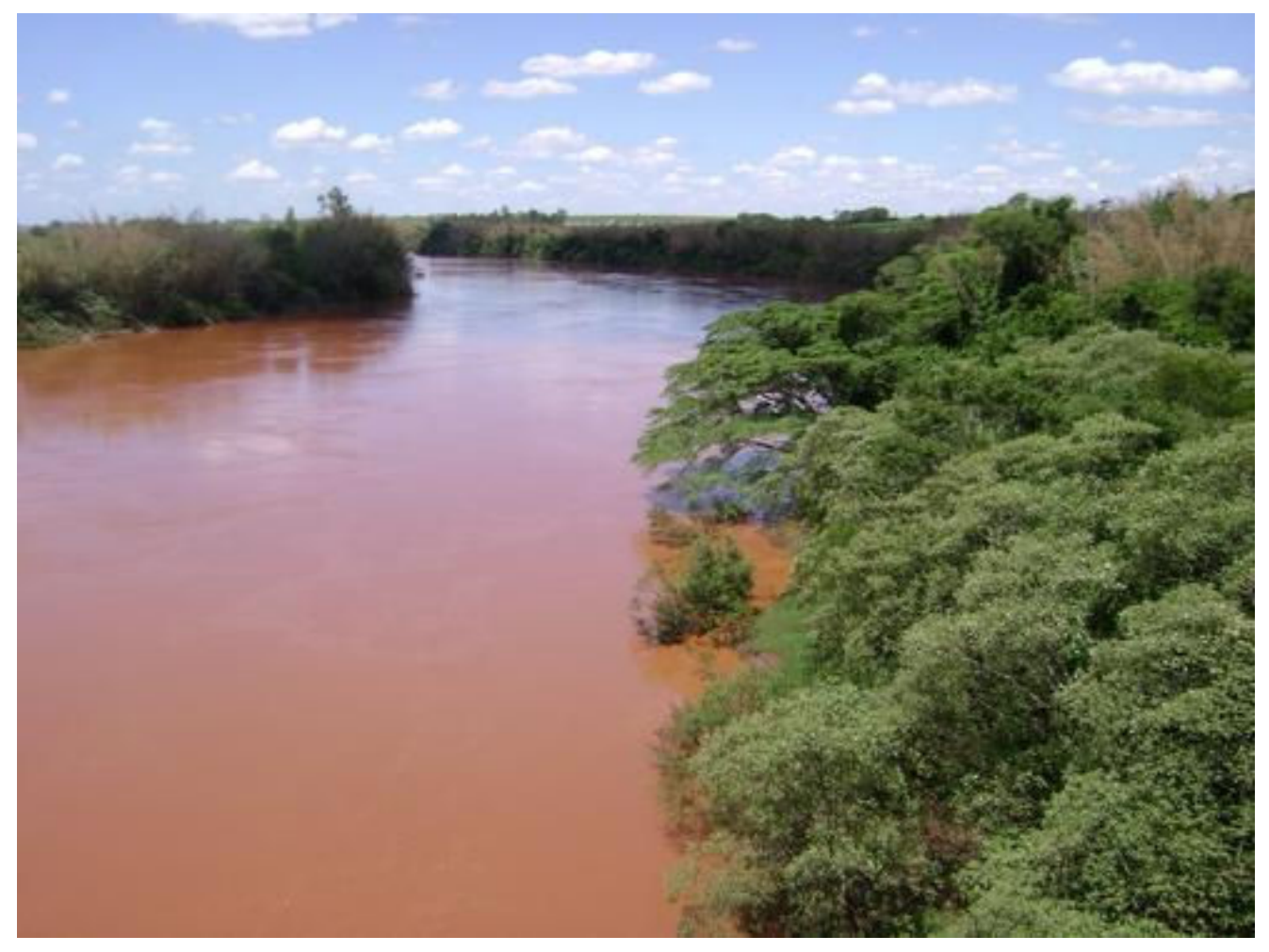

Figura 13: Foto do rio Piquiri, capturada sobre a ponte de acesso a Palotina - PR.

Segundo a classificação de Köppen para o Estado do Paraná, na área da bacia predomina o clima sub-tropical úmido mesotérmico do tipo $C f a$ com verão quente, com média do mês mais frio inferior a $18^{\circ} \mathrm{C}$ e sem estação seca definida, em função da influência das massas de ar polares e massas de ar tropicais. As temperaturas acompanham a dinâmica das massas de ar, registrando médias em torno de $20^{\circ} \mathrm{C}$ a $22^{\circ} \mathrm{C}$, enquanto as médias das máximas ficam entre $30^{\circ} \mathrm{C}$ e $32^{\circ} \mathrm{C}$ e as máximas absolutas, $38^{\circ} \mathrm{C}$, podendo chegar a $40^{\circ} \mathrm{C}$. As temperaturas médias das mínimas variam entre $10^{\circ} \mathrm{C}$ e $12^{\circ} \mathrm{C}$, com mínima absoluta em torno de $-2^{\circ} \mathrm{C}$, podendo ocorrer de 12 a 15 dias de geada por ano (IAPAR 2000).

As menores temperaturas estão associadas, principalmente, ao fator estático (orografia), e a entrada de massas polares no inverno, exemplo disso é a estação de Guarapuava situada na Serra Geral a aproximadamente $1045 \mathrm{~m}$ de altitude. As características morfoclimáticas desta região são diferenciadas em relação às demais do 
Estado. A pluviosidade situa-se entre 1.600 e $1.800 \mathrm{~mm}$ anuais sendo os meses menos chuvosos abril, julho e agosto Maack (1968), Nimer (1990) e Paraná (1990).

Leite e Klein (1990) destacam a predominância, na região, da Floresta Estacional Semidecidual, associada à atividade agropecuária. A ocorrência de florestas cobria parte do oeste e, sobretudo o extremo noroeste do Estado do Paraná. Atualmente essa formação florestal está parcialmente extinta na região e as florestas próximas aos rios da região também estão bastante modificadas, em algumas áreas a agricultura, pecuária e inclusive exploração seletiva de madeiras em algumas áreas (CAMPOS e SOUZA 1997).

$\mathrm{Na}$ bacia hidrográfica do rio Piquiri a litologia predominante decorre da Era Mesozoica, época quando ocorreram grandes derrames vulcânicos de lavas, sendo que no Período Cretáceo essas rochas foram parcialmente cobertas por sedimentos de siltitos. Segundo Mineropar (2003) as principais unidades litoestratigráficas são: a Formação Serra Geral, a Formação Caiuá e os Depósitos Aluvio-fluviais (Figura 14).

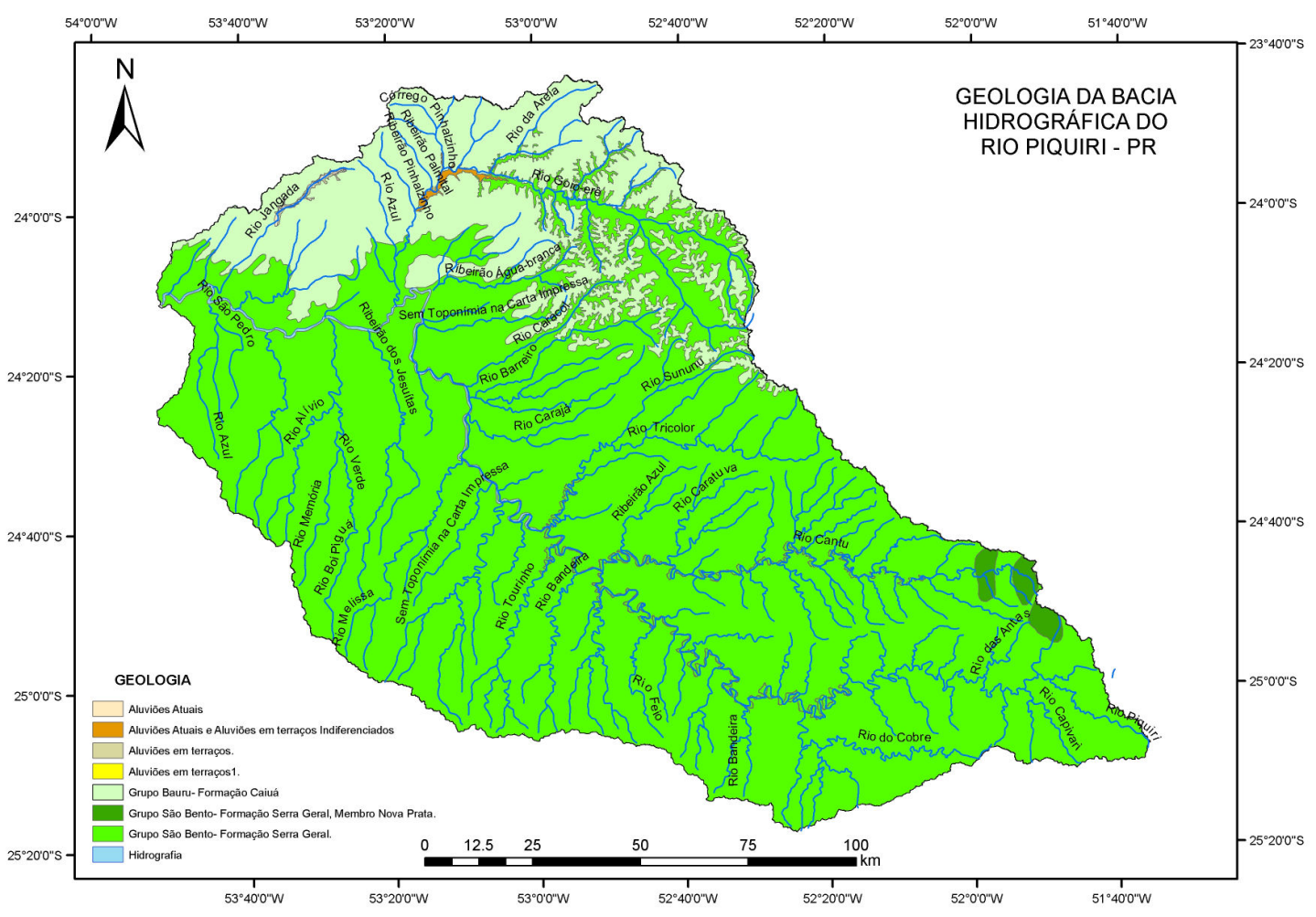

Figura 14: Geologia da bacia do rio Piquiri. Org: Aguiar (2009). Fonte Mineropar (2003). 
No Estado do Paraná, a Formação Serra Geral aparece no reverso da escarpa que separa o Segundo Planalto do Terceiro Planalto, área sob a qual a meteorização das rochas basálticas originaram um solo bastante fértil denominado coloquialmente como "terra roxa”. A Formação Serra Geral ocorre sob a forma de derrames, que se constituem numa série de unidades superpostas representativas de um intenso vulcanismo Segundo Leinz (1949), esse intenso magmatismo com manifestações intrusivas e extrusivas, de variado caráter químico ocorreu em clima árido de forma intermitente e assincrônica.

A bacia do rio Piquiri está inserida na unidade morfo-estrutural bacia sedimentar do Paraná, onde há a unidade morfo-escultural denominada de Terceiro Planalto. Este é um grande Planalto inclinado em direção oeste, que segue as camadas rochosas, com altitudes que atingem 1.100 a $1.250 \mathrm{~m}$, descendo a oeste no vale do rio Paraná em decorrência das sucessões de derrames basálticos. Os principais afluentes do rio Piquiri são: Cantu, GoiBang e Goio-Erê pela margem direita e o rio do Cobre e São Pedro pela margem esquerda.

Segundo Justus (1990), o rio Piquiri apresenta um traçado leste-oeste, constituindo um rio cataclinal de reverso, ou seja, acompanha o mergulho da camada rochosa. O seu talvegue está encaixado num vale limitado por encostas íngremes, com dissecação intensa ao longo do vale e em seus cursos médio e superior, enquanto em seu curso inferior (próximo à foz) forma terraços de várzea que alcançam em alguns pontos $1 \mathrm{~km}$ de largura. Este rio também apresenta grande quantidade de corredeiras em seu curso médio e superior.

De acordo com o mapa geomorfológico do Estado do Paraná editado no ano de 2006, no interior desta bacia encontra-se 4 unidades geomorfológicas (Figura 15).

1 - Planalto de Umuarama. Localizado ao norte da bacia, onde se verificam divisores de águas secundários e suaves colinas e platôs, com vales mais profundos em direção ao rio Ivaí, onde há dissecação predominantemente média com ocorrência de Argissolos provenientes da Formação Caiuá, sendo que no conjunto esta unidade apresenta alta vulnerabilidade a processos erosivos laminares e lineares. 2- Planalto de Campo Mourão. Localizado entre os rios Ivaí e , com altitudes que variam de $1.150 \mathrm{~m}$ na escarpa e 
a 225m, nas margens do rio Paraná. Nesta unidade predominam as mesetas e largos platôs modelados pela erosão, profundamente entalhados a sudeste. Ocorrem extensas chapadas e platôs suavemente ondulados com divisor de águas arredondados, onde há dissecação predominantemente baixa com ocorrência de solos provenientes da Formação Serra Geral, sendo que os Latossolos ocorrem no terço superior das vertentes e o Nitossolos no terço médio/inferior, com textura argilosa, associados ao relevo com baixa declividade. Recomendável para ocupação com práticas conservacionistas. 3 - Planalto de Cascavel. Localizado na direção da margem esquerda do rio Piquiri, onde há dissecação predominantemente média com ocorrência de Latossolos provenientes da Formação Caiuá, sendo que no conjunto esta unidade apresenta baixa vulnerabilidade à erosão. 4 - Planalto do Alto médio . Localizado na porção superior da bacia esta unidade apresenta dissecação predominantemente média com ocorrência de Latossolos e Neossolos provenientes da Formação Serra Geral, com textura argilosa, associados ao relevo com moderada/alta declividade. (SILVEIRA et al; 2008). 


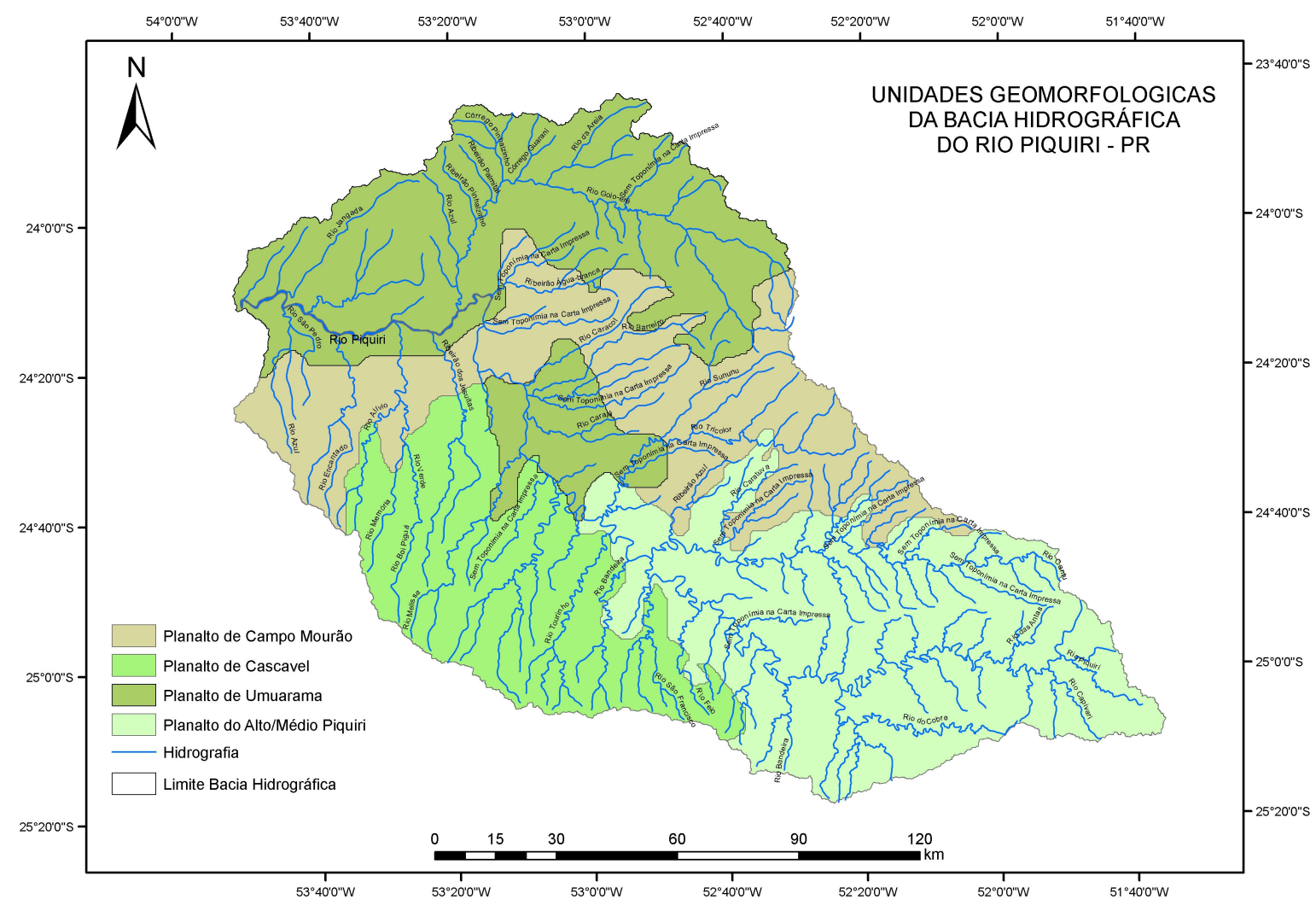

Figura 15: Distribuição das unidades geomorfológicas da bacia hidrográfica do rio Piquiri. Fonte Mineropar (2006). Org: Aguiar (2009).

Nakashima (1999) descreve que na área de ocorrência do arenito da Formação Caiuá, o relevo configura-se de forma uniforme e monótono. As altitudes variam de 600m nas áreas próximas ao contato com a Formação Serra Geral até 300m nas margens do rio Paranapanema e 250m nas margens do rio Paraná. O relevo sustentado pelos arenitos nas proximidades do contato com a Formação Serra Geral é representado predominantemente por colinas médias alongadas com topos planos e convexos e vertentes convexas. Apresenta-se diferenciado em muitas áreas, principalmente pela existência de pequenas escarpas e vales assimétricos (NAKASHIMA, 1999). 


\section{REFERENCIAIS TEÓRICO-METODOLÓGICOS}

\subsection{A ciência geomorfológica}

O termo geomorfologia (do latim geo = terra, morfo $=$ forma, logos $=$ estudo), possui um sentido que vai além do sentido literal, uma vez que seu significado possui um caráter integrador com outras ciências, principalmente sob o aspecto da escala de atuação dos processos antes e após a intervenção humana. Segundo Joly (1977), a geomorfologia é uma ciência do ramo da geografia física voltada ao estudo das formas de relevo e tem o compromisso de considerar a gênese-evolução do modelado terrestre em função dos processos de transformações contínuos no espaço-tempo. JOLY (1977) também destaca o significado desta ciência colocando em evidência as funções que lhe conferem:

- a descrição, classificação e localização das formas no terreno

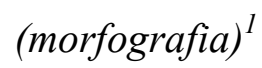

- a investigação sobre a origem das formas (morfogênese), sua evolução no tempo (morfodiacronia e morfocronologia) e sobre as formações correlativas desta evolução (morfosedimentologia)

- a determinação dos processos responsáveis pelas transformações passadas e atuais do relevo, seguida da velocidade e das consequências de suas ações (morfodinâmica)

- avaliação das dimensões das formas do ponto de vista de sua localização e de suas relações no espaço (morfometria). Conforme a necessidade, este ou aquele aspecto pode ser focalizado separadamente. Entretanto, um estudo geomorfológico só pode ser denominado como tal se realizar o conjunto destas análises.

\footnotetext{
${ }^{1}$ Morfografia que, segundo TRICART (1965) compreende a morfometria (medições de formas) e morfologia (tipologia das formas segundo a geometria e posicionamento).
} 
A respeito dessas funções é notória a progressiva complexidade e interdependência de cada uma delas que vão desde níveis descritivos, como a morfografia e, parcialmente a morfosedimentologia, para níveis explicativos, ou seja, a morfogênese, a morfocronologia e a morfodinâmica.

Em relação aos aspectos históricos de desenvolvimento teórico da geomorfologia, Abreu (1982) descreve que a grande variedade de conceitos teoria e método se confundem no campo da geomorfologia, sendo o que orienta o campo da teoria e do método é produto de duas correntes de ideias, ou paradigmas, que ao longo do tempo acabaram exercendo influência um sobre o outro.

De acordo com Abreu (1982), ao considerar os episódios geopolíticos e históricos, pode-se dizer que o início do pensamento geomorfológico foi marcado, por um lado, pelos reflexos da Revolução Industrial e, por outro, pela conquista do oeste norte-americano. A primeira corrente de ideias voltada ao surgimento da ciência geomorfológica tem origem em estudos executados por geólogos e engenheiros (europeus e norte americanos), em meados do século XIX. A publicação em 1899 de "The geographical cycle" ("ciclo geográfico") de Willian Morris Davis é conhecida como a obra do marco de fundação da moderna geomorfologia como uma ciência do ramo da geografia física.

Segundo Joly (1997), Davis “criou sobretudo, um corpo de doutrina aparentemente lógico e simples e soube coordenar de maneira coerente grande quantidade de pesquisas anteriores" e, que "sua teoria teve o mérito de separar a geomorfologia da geologia clássica e de erigi-la em disciplina independente, valorizando seus aspectos mutáveis "2

Para Davis a formação e evolução do relevo terrestre aconteciam de forma cíclica, denominada como ciclos de erosão. Sendo que no início do ciclo as forças tectônicas provocariam um rápido soerguimento das superfícies aplainadas, e com o desenrolar do tempo o processo de erosão em função do escoamento superficial dissecaria e rebaixaria o relevo até formar uma região desenvolvida por completo processo erosivo. No entanto, um

\footnotetext{
${ }^{2}$ Tradução.
} 
novo soerguimento originaria um novo ciclo, as fases do ciclo foram denominadas de juventude, maturidade e senilidade.

Outra corrente de ideia fundamental da ciência geomorfológica destacado por Abreu (1982), teve origem na Alemanha e seu alicerce estava voltado a uma concepção mais naturalista e global dos fenômenos geomorfológicos. As principais referências desta corrente são os estudos de Von Richthofen (1833-1905) e Albrecht Penck que publicou a obra "Morphologie der Erdoberflaeche" (1894), cuja importância foi a de realizar a sistematização de teorias e classificação das formas de relevo baseado em observações empíricas. Após os estudos de Albrecht Penck, seu filho Walter Penck consagrou-se como um dos grandes pensadores da ciência geomorfológica. Walter Penck foi o responsável pela ruptura do pensamento davisiano, ao apresentar uma nova proposta de estudo do relevo fundamentado na relação entre o entalhamento do talvegue e efeitos denudacionais/ agradacionais em função do comportamento dos processos tectônicos, que poderia se manifestar de forma intermitente e com intensidade variável (PENCK 1924).

Para W.Penck (1924), os processos denudacionais e agradacionais resultam da relação entre os processos endogenéticos e exogenéticos. Assim, a evolução do relevo não corresponde a uma única forma de evolução baseada em ciclos de erosão, mas sim pela existência de uma grande variação e inúmeras possibilidades de evolução das formas do relevo em função da intensidade dos processos de transformação, isto é, trata-se de um sistema de ideias que contrapõem a proposta do "ciclo geográfico" de Davis. No final da década de 30 do século passado, os pesquisadores norte-americanos começaram a se interessar pela integração dos estudos de W.Penck com a proposta de Davis, e um desses pesquisadores interessados por esta relação foi Lester C. King (1953).

Segundo King (1953), os rápidos e intermitentes soerguimentos dos processos tectônicos são separados por longos períodos de estabilidade. Ao mesmo tempo em que estabeleceu o conceito de estabilidade tectônica considerado por Davis, King utiliza o conceito de recuo paralelo das vertentes de W. Penck como forma de explicação da 
evolução das formas de relevo. Sua contribuição propõe um esquema mais detalhado de atuação dos processos erosivos no relevo, com destaque para a destruição dos pontos elevados por recuo (desagregação mecânica) e consequentemente entalhamento de depressões (elevação do nível de base) proporcionando a pediplanação. As ideias de King foram uma das grandes contribuições para a geomorfologia, inclusive por introduzir as variáveis de origem climáticas como um dos principais componentes de esculturação do relevo.

Entre a década de 40 e 60 do século passado, os estudos de Horton (1945), Strahler (1950), foram de grande importância no cenário de desenvolvimento da geomorfologia aplicada, uma vez que enfatizam a teoria geral dos sistemas aplicada em análises topológicas da rede de drenagem e levantamento de variáveis morfométricas das bacias hidrográficas. Anos depois, John T. Hack apresenta uma importante contribuição a geomorfologia ao utilizar os sistemas propostos por Davis e Penck e o emprego da teoria geral dos sistemas, anteriormente aplicada por Horton e Strahler, a fim de contextualizar as déias propostas por Gilbert (1877), e criar o conceito de "equilíbrio dinâmico".

Ao formular os princípios básicos de sua teoria, Hack (1960), considera que o relevo é um sistema aberto, no qual ocorrem constantes trocas de energia e matéria com os demais sistemas. Este mesmo autor também verificou que a declividade dos canais fluviais diminui com o comprimento do rio e varia em função da litologia no qual escoa com isto ele evidenciou o a resistência litológica na evolução do relevo e do potencial da forças erosivas em função da influência climática, atuantes no equilíbrio dinâmico das formas.

Na ex U.R.S.S Gerassimov e Mecerjakov (1968), apoiados na concepção de W. Penck fornecem uma nova direção teórico-metodológica para os estudos geomorfológicos como base conceitual para análise morfoestrutural e sua correspondente cartografia geomorfológica, onde o relevo é classificado em três categorias genéticas: a geotextura, a morfoestrutura e a morfoescultura Abreu (1982). 
Interessante destacar diante todo o desenvolvimento da ciência geomorfológica o pesquisador russo Doukouchaiev (1883), uma vez que foi ele quem pela primeira vez fez referência do reconhecimento dos solos como um corpo natural formado pela ação de um grupo de agentes de formação. Outro autor de destaque é Koppen (1900), cujas pesquisas referentes ao caráter de zoneamentos dos fenômenos da natureza com base climática contribuíram anos mais tarde para o desenvolvimento dos estudos de J. Büdel (1920).

Outro aspecto relativo ao desenvolvimento da geomorfologia foi à aplicação do conhecimento geomorfológico em estudos territoriais. Este fato é um interessante indicador de desenvolvimento da geomorfologia, principalmente no início na década de 70 do século passado, onde inúmeros estudos geomorfológicos estavam intensamente relacionados com a temática ambiental, especialmente quando foram apresentados resultados de diversas estudos no $1^{\circ}$ Simpósio de geomorfologia em Binghamton cujo tema foi "Environmental Geomorphology” (1970).

No Brasil o desenvolvimento desta disciplina foi direcionado por pesquisadores franceses, os quais eram fortemente influenciados pelas teorias de Davis, com destaque para Martone (1950), Tricart (1959), Bertrand (1968). Estes pesquisadores influenciaram enormemente o desenvolvimento da geografia e geomorfologia brasileira sob a égide davisiana. Em relação à influência germânica na geomorfologia brasileira, Abreu (1982), destaca Ab'Saber (1969), por ter estabelecido os níveis de abordagem geomorfológica baseados na compartimentação topográfica do relevo e reconhecimento da estrutura superficial da paisagem sob influência dos processos morfoclimáticos-pedogêneticos. Segundo Abreu (1982), a proposta de Ab'Saber (1969), permite uma flexibilidade para ajuste dos fatos estudados sob diferentes escalas (espaciais e temporais), além de valorizar a perspectiva geográfica.

Após a década de 60 do século passado, os estudos geomorfológicos no Brasil conhecem novos cenários de desenvolvimento por meio da incorporação de conceitos relativos à teoria geral dos sistemas e ideias referentes ao equilíbrio dinâmico dos 
fenômenos geomorfológicos, com destaque para as publicações de Antonio Christofoletti. É deste autor as principais publicações que norteiam os iniciados em geomorfologia no Brasil, com destaques para publicação do livro Geomorfologia (1974), o qual é visivelmente um livro de caráter didático em virtude das traduções das principais referências metodológicas para emprego da geomorfologia sob a óptica da teoria dos sistemas.

Guerra e Marçal (2006), a respeito da importância dos estudos geomorfológicos destacam que no Brasil a geomorfologia vêm ganhando espaços pela pertinência da aplicação direta dos seus conhecimentos voltados à análise ambiental e desenvolvimento crescente da sociedade, além de fornecer procedimentos que apontam na direção do encontro de soluções. Assim, o conhecimento geomorfológico se insere na ótica de um instrumento a ser utilizado e inserido na execução de diversas categorias setoriais do planejamento. Exemplos diversos podem ser listados, como a aplicabilidade no planejamento do uso do solo rural e urbano, aproveitamento dos recursos hídricos, obras de engenharia, no planejamento ambiental, nas pesquisas de recursos minerais e recuperação de áreas degradadas, além da classificação de terrenos.

Este breve resgate histórico tem o objetivo de definir o objeto e campo da disciplina, como também fornecer insumos para se avaliar a origem de conceitos, e entendimento das questões terminológicas e conceituais que se ampliam no contexto deste estudo de geomorfologia aplicada.

Em relação a tendência atual da geomorfologia Rodrigues (1997) descreve as seguintes considerações:

Há uma tendência em separar a geomorfologia em pura e aplicada, atribuindo exclusivamente a esta última, as fases de interpretação e adaptação do conhecimento geomorfológico gerado pela primeira. Adaptações, interpretações, decodificações, apropriações estas, realizadas para fins de absorção em processos de planejamento dos mais variados. Dentro destes processos e, portanto, dentro das práticas externas à 
academia, há um espaço para a ciência pura que esta mais associada a uma de suas fases, a de diagnose. Se há propósitos distintos e semelhantes entre a geomorfologia pura e aplicada, é preciso tomar um certo cuidado quanto à sobrevalorização ou substituição de uma em detrimento de outra. Nos últimos dez ou vinte anos, tanto no Brasil, como ao nível internacional, houve um desenvolvimento expressivo da geomorfologia aplicada. Mas isto não deve significar que a geomorfologia pura tornou-se menos importante. Ao contrário, o fluxo entre ambas deve ser altamente produtivo. A geomorfologia aplicada não sobrevive sem a geomorfologia pura, mas pode colocar em cheque o conhecimento teóricometodológico, trazendo novas questões à ordem do dia. Não é possível, portanto, afirmar que a geomorfologia aplicada seja algo muito diferente de geomorfologia pura. Na realidade, a geomorfologia aplicada a inclui e necessita ir além.

Hart (1986), em "Geomorphology, Pure and Applied", apresenta os conteúdos da tendência atual da geomorfologia aplicada, os quais foram tratados preferencialmente em sua obra:

-estudo das formas e processos responsáveis, -propriedades dos materiais que os compreendem e, -métodos e técnicas utilizados para a análise destes elementos de geomorfologia pura (HART,1986).

Esta subdivisão demonstra a concretização precisa a respeito do objeto de estudo da geomorfologia, que na tentativa de descrever e explicar as formas e os processos, assume de forma categórica o estudo dos materiais. 


\subsection{Geomorfologia fluvial e a análise sistêmica de bacias hidrográficas}

O foco dos estudos de geomorfologia fluvial são os processos e as formas condicionadas a ação do escoamento dos rios, os quais são responsáveis pelo transporte de matéria e energia. Para Orme (2002), o desenvolvimento da geomorfologia fluvial partiu principalmente de estudos que estiveram relacionados à teoria do regime de fluxo uniforme das águas, onde a velocidade de escoamento é constante em qualquer ponto dentro dos canais fluviais e as forças de resistência e atrito são iguais e opostos ao da declividade gravitacional impelida pela força da água.

A teoria do regime de fluxo uniforme das águas foi discutida nos estudos de Leopold et al., (1964), publicados no livro "Fluvial Processes in Geomorphology", que atualmente é uma das referências clássicas para as pesquisas de geomorfologia fluvial. Entretanto, o entendimento do fluxo fluvial foi discutido num período anterior de aproximadamente 200 anos nos estudos de Edme Mariotte (1620-1684), que demonstrou o perfil vertical e a velocidade dos rios, e também nos estudos de Domenico Guglielmini (ORME 2002).

Segundo Orme (2002), Domenico Guglielmini foi matemático, hidráulico, físico, professor de medicina e fez grandes contribuições para entendimento dos canais abertos de água. Ele investigou a variação da velocidade de fluxo, profundidade e declividade, na natureza do fluxo aceleração e resistência do leito do canal, e também a relação entre geometria do canal e transporte dos sedimentos. Para este pesquisador a observação é mais eficiente que a experimentação e que, consequentemente, o campo é melhor que o laboratório. Suas ideias foram posteriormente refinadas progressivamente no século XVIII por Bernoulli e Brahms. Apesar disso, outras contribuições foram ignoradas por outros estudiosos nos anos seguintes, inclusive a teoria do regime de fluxo uniforme de um rio, creditada a Antoine de Chézy (1718-1798). 
Chézy passou maior tempo de sua vida como coordenador da l'Ecole des Ponts et Chaussées na França e em 1768 foi responsável por coordenar a construção de um canal para transpor água do rio Yvette até Paris. Neste período formulou parâmetros para determinação das características de um canal a partir de medições obtidas em um outro. No entanto, suas descobertas ficaram no anonimato por quase um século, e foram encontradas pelo Engenheiro Norte Americano Clemens Herschel (1987) apud (ORME 2002).

Abreu (1980), sobre o estudo "Etude sur lês torrents dês Hautes Alpes" publicado em Paris no ano 1841 por Alexandre Surell, destaca este como uma obra fundamental voltada para compreensão do trabalho dos rios e sua influência nos processos de modelagem do relevo terrestre. Estas ideias forneceram as premissas básicas para o desenvolvimento da geomorfologia fluvial e das principais teorias geomorfológicas que vão desde a abordagem davisiana do "Ciclo geográfico", ao principio de mobilidade de Penck (1924), além do emprego da teoria geral dos sistemas para definição do conceito de equilíbrio fluvial conforme exposto por Hack (1960).

Para entendimento do sistema geomorfológico, observa-se que formas e processos estão fortemente correlacionados e o estudo de ambos são elementos fundamentais, porém, as formas, os processos e suas interrelações não compõem um sistema isolado, uma vez que um sistema recebe e também exerce influencias sobre outros sistemas. O emprego do conceito de sistema em geomorfologia remete a referência feita pelo biólogo Ludwing Von Bertalanffy (1950), a respeito da teoria geral dos sistemas. Para este autor um sistema pode ser definido como um complexo de elementos em constante interação, isto significa que os elementos se relacionam de maneira que o desempenho de um elemento é diferente de seu comportamento em outra relação.

Nos estudos geomorfológicos a teoria dos sistemas possibilitou uma abordagem sistêmica e integrada dos fenômenos representados por parâmetros que definem as variáveis de estado e transformação do relevo, sem escapar da lógica escalar do espaçotempo, extremamente importantes quando se busca a análise da natureza dos elementos e 
suas interrelações em diferentes espaços, como também a interrelação de suas partes. Assim, as partes de um determinado sistema potencializam as modificações de outros sistemas e os resultados das interações são novos padrões observáveis em diferentes escalas. Para Holland (2002), a ação de uma variável afeta possivelmente as ações subsequentes de outras do conjunto, de modo que a ação do todo é, em determinados aspectos, mais do que a simples soma das ações de suas partes.

De acordo com Christofoletti (1974), o sistema geomorfológico representa o conjunto dos elementos e das relações entre si e entre seus atributos. No entanto, há dificuldades a serem superadas quando se propõem conceituar os fenômenos como sistemas, por exemplo, identificar os elementos, seus atributos e suas relações. Praticamente a totalidade dos sistemas que interessam ao geomorfólogo não atua de modo isolado, mas funciona dentro de um ambiente que faz parte de um conjunto maior. O conjunto maior do sistema é denominado universo, e no seu interior existem os chamados sistemas antecedentes (os fenômenos) e sistemas subsequentes (os eventos). Existe um mecanismo de retroalimentação (feedback), onde os sistemas subsequentes voltam a exercer influências sobre os antecedentes, configurando uma perfeita interação. Vários aspectos devem ser considerados no estudo da composição dos sistemas, entre estes a matéria, energia e estrutura.

Segundo Christofoletti (1974), a matéria corresponde ao material mobilizado através do sistema, por exemplo, no sistema hidrográfico a matéria pode ser representada pela água e sedimentos. A energia corresponde às forças que fazem o sistema funcionar, gerando a capacidade de realizar trabalho pela entrada de diferentes fluxos provenientes da radiação térmica do sol, energia potencial-cinética da precipitação e energia química. A saída da energia se dá pela eliminação de água, sedimentos e materiais solúveis ao longo dos canais abertos e subterrâneos. A estrutura é constituída pelos elementos e suas relações, expressando-se através do arranjo de seus componentes: elemento (unidade básica do sistema); surge aqui à problemática da escala: um rio é elemento no sistema hidrográfico, 
no entanto, pode ser concebido como um sistema em si mesmo. Três características principais das estruturas devem ser observadas: tamanho (determinado pelo número de variáveis que compõem o sistema), correlação (a correlação entre as variáveis em um sistema expressa o modo pelo qual elas se relacionam), causalidade (mostra qual é a variável independente, a que controla e a dependente).

Para Cunha (2001), “é impossível compreender o relevo sem considerar os fluxos de matéria e energia responsáveis por sua gênese e esculturação", desta forma enfatiza a importância do emprego da teoria geral dos sistemas nos estudos geomorfológicos, pois o relevo sendo fruto da interação de diversos fatores necessita que estes sejam estudados para que as formas sejam compreendidas.

No desenvolvimento da geomorfologia foi com a introdução dos princípios da teoria geral dos sistemas que o conceito de equilíbrio passou a ser entendido como o ajustamento completo das variáveis internas de um sistema às condições externas (CHRISTOFOLETTI, 1974). Isto significa, em linhas gerais, que materiais, processos e formas de relevo compõem um conjunto autorregulador, e que toda forma é o produto do ajustamento de materiais e processos. Sob esta perspectiva a abordagem sistêmica empregada na análise comparativa de bacias hidrográficas parte inicialmente da sistematização de cada bacia hidrográfica como um sistema geomorfológico não isolado, aberto, onde estão presentes as variáveis morfológicas e hidrodinâmicas, sob as quais atuam processos que determinam o comportamento de cada bacia hidrográfica. Sendo que a estrutura de cada bacia hidrográfica condiciona as variáveis de estado e transformação responsáveis por reajustes em todo o sistema.

As variáveis de estado do sistema relacionam e se transformam por processos climáticos e geomorfológicos, entendidos como variáveis de transformação, com destaque para: a erosão, transporte, precipitação, oscilação do nível fluviométrico, fluxo do escoamento, morfogênese/pedogênese entre outros. A mobilização das variáveis de transformação ocorre por meio dos fluxos de energia e matéria. Portanto, as variáveis de 
estado e transformação representam o cenário ou estrutura dos sistemas, onde os processos determinam um comportamento específico para cada um, sendo que as alterações das variáveis, seja somente uma, provoca ajuste em todas as outras. Caso seja desconsiderada a dependência ou independência das variáveis e relação com outros sistemas, o sistema representará uma estrutura parcial, o que em certos aspectos impossibilita a condução de uma pesquisa.

Os processos atuantes nos sistemas fluviais, imprimem transformações na configuração da rede de canais de drenagem, seja dos canais inseridos na superfície e/ou sub-superfície de uma bacia hidrográfica. Um intrigante processo geomorfológico que ocorre em bacias hidrográficas, está relacionado à captura de canal de um rio por outro. Jukes (1862) apud Thornbury (1957), foi um dos primeiros pesquisadores a reconhecer o fenômeno de captura fluvial. Isto ocorreu, quando ele investigou a formação dos vales de alguns rios da região sul da Irlanda, onde foi constatado de fato que um canal poderia aparentemente apropriar outro canal de drenagem e formar um vale abandonado. $\mathrm{O}$ estudo de Jukes é considerado como um dos panos de fundo para desenvolvimento da geomorfologia fluvial na Europa, e no contexto deste estudo credita-se a ele a primeira referência científica relacionada ao fenômeno geomorfológico de captura fluvial, que também é conhecido como processo de piratagem de canais. O termo "piratagem", assim como, o significado relacionado a grupos de marginais que cruzam os mares com intenção de promover saques e pilhagem em barcos e navios, representa de forma metafórica o ato de captura do canal de um rio por outro, muitas vezes localizados distantes um do outro.

Na língua inglesa é possível encontrar os seguintes sinônimos para captura fluvial: stream capture, river capture; piracy; stream piracy, river piracy, robbery, stream robbery (BATES; JACKSON 1997). Geólogos utilizam o conceito "curto-circuito hidrológico" como sinônimo de captura fluvial, ou seja, um canal comete captura quando viola o limite topográfico de outro canal localizado numa área de menor gradiente topográfico, subtraindo seu canal e seus fluxos, ou a maioria dos rios a jusante para formar uma nova rede 
hidrográfica, uma das principais evidências de capturas são os cotovelos de captura (elbows of capture), rios residuais (misfit streams) colos ou vales mortos, secos ou abandonados (cols or wind-gaps) (MILLER,1915), e rupturas interpretadas por meio do perfil longitudinal fluvial (river profile) (SMALL, 1977).

Segundo Rodrigues e Adami (2005), a maioria dos estudos de bacias hidrográficas são realizados sob os aspectos hidrodinâmicos e morfométricos. Os primeiros têm sido desenvolvidos principalmente em função da necessidade de inventariar o potencial hidroenergético de bacias hidrográficas. Os morfométricos podem servir para as interpretações hidrodinâmicas e geomorfológicas, possibilitando interpretações sobre a gênese e a dinâmica atual (morfodinâmica) do sistema bacia hidrográfica.

Desta forma, admite-se que neste estudo as bacias hidrográficas podem ser mais ou menos complexas que outras, e algumas podem apresentar grande quantidade de variáveis e ter seus parâmetros em equilíbrio dinâmico, ou outras bacias, com pequena quantidade de variáveis terem seus parâmetros em desequilibro. 


\subsection{Análise morfométrica da rede de drenagem e de bacias hidrográficas}

Foram os pesquisadores dos EUA que deram início às primeiras pesquisas voltadas ao levantamento das propriedades morfométricas de bacias hidrográficas, além dos estudos dos processos e quantificação em geomorfologia no intuito de investigar a origem e desenvolvimento dos rios e vales. O engenheiro hidráulico Robert Elmer Horton foi o precursor na realização de uma interpretação quantitativa da rede de drenagem. Até então, os estudos voltados à análise de bacias hidrográficas por muito tempo se restringiram às descrições qualitativas, baseadas em observações pessoais e raciocínios indutivos (CHRISTOFOLETTI 1970).

A partir dos estudos de Horton (1945), iniciou-se a investigação científica da organização das redes de drenagem apoiado em análises quantitativas da rede de drenagem sob inúmeros aspectos de abordagem analítica. Sua proposta contribuiu para caracterização e estruturação das redes de drenagem, baseando-se na comparação dos segmentos das diversas ordens dos rios. Em suma ele propôs uma análise quantitativa da rede de drenagem para avaliação do estado de equilíbrio dinâmico da rede de drenagem. Arthur Newell Strahler (1957), sob a perspectiva topológica da rede de drenagem realizou o aperfeiçoamento da interpretação de Horton referindo-se apenas as interconexões, não importando os comprimentos, formas ou orientações das ligações.

$\mathrm{Na}$ análise morfométrica de bacias a rede de canais de drenagem pode ser descrita de acordo com a organização dos canais, além de descrições de padrões ou formas, sendo que também é possível efetuar descrições quantitativas de vários aspectos da organização da drenagem intimamente associada com a geometria hidráulica dos canais e as formas dos perfis longitudinais dos rios. Assim, as combinações de diferentes variáveis permitem a identificação de padrões morfológicos de canais fluviais (LEOPOLD et al., 1964).

Para Suguio e Bigarella (1990), a rede de drenagem é dependente de inúmeros fatores, entres estes, a pluviosidade, a topografia, a cobertura vegetal, os solos, a litologia e 
a estrutura das rochas. Algumas das características mais importantes das redes de drenagem influenciadas por esses processos são: a densidade de drenagem e o seu arranjo espacial, cujos aspectos são fortemente controlados pela estrutura litológica, por exemplo, as áreas mais impermeáveis apresentam uma rede de drenagem mais densa, enquanto os terrenos mais permeáveis possuem densidade menor.

Para Doornkamp e King (1971), a análise numérica das características morfométricas de uma bacia hidrográfica proporciona o conhecimento da área, e de cada estágio de desenvolvimento das forças que atuam sob as formas. Sendo assim, analisar as bacias hidrográficas de maneira isolada ou integrando-as em um conjunto, é de relevante importância para a geomorfologia, ou seja, as bacias hidrográficas como unidades convenientes de análise vêm-se tornando objeto de investigação geomorfológica cada vez mais empregado, pois estas são o cenário da evolução da paisagem como um todo. Segundo Doornkamp (1986), “a evolução de uma paisagem é igual à soma total da evolução individual de cada bacia de drenagem, na qual a paisagem se compõe”.

Abrahams (1984), a respeito da rede de drenagem destaca que sua morfologia é intrinsecamente herdada do passado ou fortemente influenciada por formas herdadas, e que as atividades antrópicas têm as alterado significativamente principalmente em função das características topográficas, contribuindo para uma maior suscetibilidade a processos erosivos.

No Brasil o estudo de Freitas (1952), publicado no Boletim Paulista de Geografia $\left(n^{\circ} 11\right)$, foi o primeiro estudo de análise morfométrica de bacia hidrográfica a ser realizado no país. Neste estudo foi abordada a questão da textura topográfica da rede de drenagem e sua aplicação em estudos geomorfológicos. Em 1968 são publicados outros estudos de morfometria, com destaque para Tolentino et al., (1968), e Gandolfi (1968). Neste mesmo período Christofoletti (1970) ao realizar sua tese de livre docência, expõe a importância do estudo morfométrico para levantamento de índices, relações e valores, a fim de reconhecer o potencial hidroenergético dos recursos hídricos superficiais. São propostos em seu estudo 
os seguintes tipos de análises de bacias hidrográficas: análise linear e areal. Anos mais tarde Christofoletti (1974), propõe outros tipos de análises morfométricas de bacias hidrográficas, sistematizadas em quatro categorias, a saber: análise linear; análise areal; análise hipsométrica e análise topológica.

Neste estudo, que pretende realizar análises morfométricas de duas bacias hidrográficas os resultados serão comparados de forma a possibilitar o reconhecimento dos parâmetros intervenientes na liberação ou estocagem de sedimentos em suspensão em direção ao rio Paraná e reservatório de Itaipu.

Para efeito de melhor esclarecimento dos parâmetros das análises hidrogeomorfológicas e hidrossedimentológicas a seguir é apresentada uma descrição das análises e os parâmetros adotados, os quais servirão para comparações das bacias hidrográficas dos rios Iguatemi-MS e Piquiri-PR. 


\subsubsection{Análise hierárquica e linear da rede de drenagem}

A análise da rede de drenagem de bacias hidrográficas compreende a contagem, hierarquização e mensuração dos elementos lineares e por meio destes serão analisadas as características dos parâmetros morfométricos de diferentes bacias hidrográficas. Algumas destes parâmetros não possuem relação direta com a estocagem ou liberação de sedimentos em suspensão, mas tratando-se de um estudo de comparação de diferentes sistemas estes são representativos quando a descrição e quantificação dos sistemas fluviais.

\section{- A análise hierárquica da rede de drenagem}

A proposta de ordenação dos canais de uma rede drenagem feita por Arthur N. Strahler em 1952, é resultado da adaptação da proposta de Horton (1945), sob a perspectiva topológica da rede de drenagem, referindo-se apenas as interconexões, não importando os comprimentos, formas ou orientações das ligações (Figura 16).

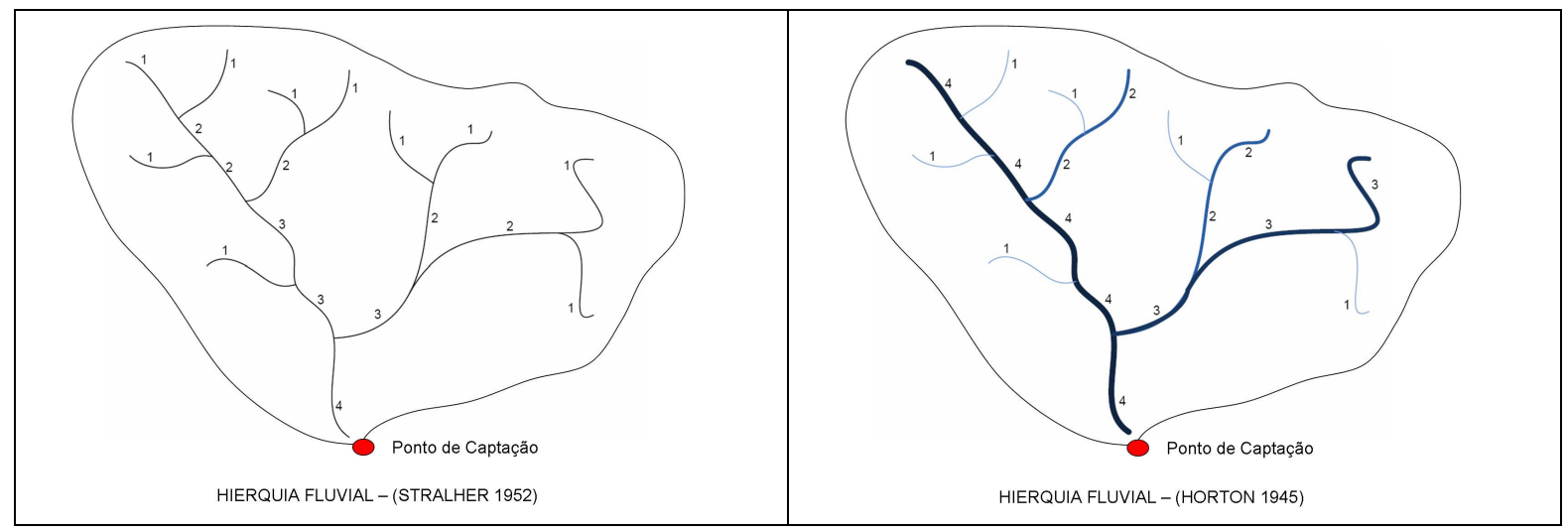

Figura 16: Comparação entre a metodologia de Horton e Strahler para ordenação da rede de drenagem. Org: Aguiar (2009).

O critério de Strahler (1952), estabelece que os trechos de drenagem sem tributários sejam considerados como de $1^{\mathrm{a}}$, ordem estendendo-se da nascente até a confluência com 
outro. Quando dois tributários de $1^{\mathrm{a}}$ ordem se encontram formam um segmento de $2^{\mathrm{a}}$ ordem; quando dois canais de ordens diferentes se unem prevalece o de maior ordem, e assim por diante até a ultima ordem que corresponde à ordem geral da bacia. Destacam-se as seguintes variáveis da hierarquização: - ordem de canais $(\mathrm{u})$ - número de canais de cada $\operatorname{ordem}\left(\mathrm{N}_{\mathrm{u}}\right)$; - número total de canais $(\mathrm{Nt})$.

Para Dodds e Rothmam (1999), a hierarquização dos canais é um procedimento básico é extremamente importante para a análise dos sistemas de drenagem, uma vez que fornece subsídios para realização de comparações entre redes de drenagem de diferentes bacias hidrográficas.

\section{- A análise linear da rede de drenagem}

Este tipo de análise é resultado de índices e valores de mensurações efetuadas sob representações gráficas da rede de drenagem. Para isto são aplicados procedimentos técnicos específicos que vão desde processos manuais, ou, automatizados por meio do processamento digital de modelo digital de elevação (MDE) e aplicação de sistemas de informações geográficas (SIG).

Nesta categoria de análise da rede de drenagem destacam-se:

\section{a) Relação de bifurcação}

Inicialmente proposta por Horton (1945), trata-se da relação entre o número total de canais de determinada ordem e o número total dos de ordem ou hierarquia superior. Segundo Strahler (1964), a relação de bifurcação difere de uma ordem à outra, por causa das variações na geometria da bacia. Esta observação é baseada na lei do número de canais de Horton (1945), onde o número de canais de cada ordem $\left(\mathrm{N}_{\mathrm{u}}\right)$ forma uma série geométrica inversa com o número de ordem $(\mathrm{u})$, onde o primeiro termo é a unidade de 
primeira ordem, e a razão a relação de bifurcação $(\mathrm{Rb})$. Esta variável é um indicador do grau de dissecação de uma bacia hidrográfica, uma vez que, quanto maior for o valor maior o será o grau de dissecação.

$$
\mathrm{Rb}=\underline{\mathrm{N}}_{\mathrm{u}}
$$

Sendo:

$\mathrm{Rb}=$ relação de bifurcação;

$\mathrm{N}_{\mathrm{u}}=$ número de segmentos de determinada ordem;

$\mathrm{N}_{\mathrm{u}+1}=$ número de segmentos de ordem superior.

Para Strahler (1964), a relação de bifurcação não será exatamente igual de uma para outra ordem, por causa das variações na geometria da bacia, e seu valor varia normalmente entre 3,0 e 5,0 .

\section{b) Comprimentos dos canais}

Nesta categoria enquadram-se as medições referentes ao comprimento do canal principal da bacia e de canais conforme a sua ordem.

- comprimento do canal principal (Lp) - Para Christofoletti (1974), é à distância da foz até a nascente, para estudos regionais costuma-se utilizar a unidade de medida em $\mathrm{km}$.

- comprimento médio dos canais de cada ordem ( $\left.\mathbf{L m}_{\mathbf{u}}\right)$ - Para Christofoletti (1974), representa a relação entre a extensão total dos rios e o número total de rios. 


$$
\mathrm{Lm}_{\mathrm{u}}=\frac{\underline{\mathrm{L}}_{\mathrm{u}}}{\mathrm{N}_{\mathrm{u}}}
$$

Sendo:

$\mathrm{Lm}_{\mathrm{u}}=$ comprimento médio dos rios de determinada ordem $(\mathrm{km}) ;$

$\mathrm{L}_{\mathrm{u}}=$ extensão total dos canais de cada ordem $(\mathrm{km})$;

$\mathrm{N}_{\mathrm{u}}=$ número total de rios de cada ordem.

\section{c) Relação dos comprimentos.}

Segundo Horton (1945), a relação dos comprimentos tende a ser constante ao longo das sucessivas ordens de uma bacia, onde os comprimentos médios dos canais tendem a aumentar segundo uma progressão geométrica.

$$
\mathrm{Rlm}=\underline{\mathrm{Lm}}_{\mathrm{L}}^{\mathrm{L}-1}
$$

Sendo:

$\mathrm{R} \operatorname{lm}=$ relação dos comprimentos médios dos canais;

$\mathrm{Lm}_{\mathrm{u}}=$ comprimento médio dos canais de determinada ordem $(\mathrm{km})$;

$\mathrm{Lm}_{\mathrm{u}-1}=$ comprimento médio dos canais de ordem inferior $(\mathrm{km})$.

\section{d) Relação entre a relação do comprimento médio dos canais e a relação de bifurcação}

Horton considera este parâmetro de fundamental importância para análise da capacidade de armazenamento hídrico na rede de drenagem que, por sua vez, é o principal fator na intensidade da definição dos picos de cheia. Se o valor da relação entre $\mathrm{Rlm} / \mathrm{Rb}$, for elevado, significa que comprimento principal dos canais de ordem superior terá um melhor 
armazenamento de água durante as cheias, e assim, atenuar os efeitos erosivos de vazões de forte intensidade (HORTON 1945).

Segundo Christofoletti (1974), a relação entre a relação de comprimento médio dos canais e de bifurcação é um parâmetro que possibilita a aplicação de análises a respeito do desenvolvimento fisiográfico das bacias hidrográficas.

$$
\mathrm{Rlb}=\frac{\mathrm{Rlm}}{\mathrm{Rb}}
$$

Sendo:

$\mathrm{Rlb}=$ relação do comprimento médio dos canais e a relação de bifurcação;

$\mathrm{R} \operatorname{lm}$ = relação dos comprimentos médios dos canais;

$\mathrm{Rb}=$ relação de bifurcação.

\section{e) Gradiente do canal principal}

Enunciado inicialmente por Horton (1945), e posteriormente por Strahler (1952), o gradiente do canal principal é a relação entre a diferença máxima de altitude entre o ponto de origem e o término com o comprimento do canal fluvial. Sua finalidade é indicar a declividade de um canal fluvial e com isto verificar o potencial de mobilização ou estocagem de sedimentos em suspensão das bacias hidrográficas.

O gradiente pode ser calculado por meio da seguinte equação:

$$
\mathrm{Gcp}=\frac{\text { Alt.max }}{\text { Lp }}
$$

Sendo: 
Gcp = gadiente do canal principal (\%);

Alt.max = atitude máxima $(\mathrm{m})$;

$\mathrm{Lp}=$ comprimento do canal principal $(\mathrm{km})$.

\section{f) Extensão do percurso superficial}

Proposto por Horton (1945), este índice representa o comprimento do caminho percorrido pelas águas pluviais, considerando uma linha reta em direção um trecho de drenagem, ou seja, é uma estimativa da distância do local onde houve a chuva até o ponto mais próximo no leito de um trecho de drenagem. O resultado obtido é aplicado para caracterizar a textura topográfica da superfície da bacia hidrográfica e analisar o maior ou menor espaçamento entre os trechos de drenagem. Além disto, neste estudo seu emprego está relacionado ao potencial para geração de sedimentos em suspensão das bacias hidrográficas, onde quanto menor o valor de Eps maior será seu potencial, uma vez que a distância para mobilizar os materiais da superfície das vertentes será menor.

$$
\text { Eps }=\frac{1}{(2 \times D d)} \times 1000
$$

Sendo:

Eps = extensão média do percurso superficial (m);

$\mathrm{Dd}=$ densidade de drenagem $\left(\mathrm{km} / \mathrm{km}^{2}\right)$;

$1000=$ fator de conversão. 


\subsubsection{A análise hierárquica e areal de bacias hidrográficas}

Assim como análise morfométrica da rede de drenagem, a análise das bacias hidrográficas compreende a contagem, hierarquização das áreas de drenagem direta por ordem de canal, e mensuração de parâmetros lineares e areais.

\section{- Análise hierárquica}

Adotando o critério de Strahler (1952), para hierarquização dos trechos de drenagem é estabelecido o mesmo critério para ordenação das bacias, ou seja, as bacias de tributários de $1^{\mathrm{a}}$ ordem são consideradas como bacias de $1^{\mathrm{a}}$ ordem. Quando duas bacias de $1^{\mathrm{a}}$ ordem se encontram, formam uma bacia de $2^{\mathrm{a}}$ ordem; quando duas, de ordens diferentes se unem, prevalece a de maior ordem, e assim por diante até a ultima ordem que corresponde à ordem geral da bacia. Destacam-se as seguintes variáveis da hierarquização. - ordem das bacias $(\mathrm{u})$ - número de bacias de cada ordem $\left(\mathrm{Nb}_{\mathrm{u}}\right)$; - número total de bacias $(\mathrm{Nbt})$.

\section{- Análise areal}

As variáveis da análise areal consideram as grandezas bidimensionais, ou parâmetros provenientes de medições planimétricas, além de medições lineares da rede e da bacia de captação. Da mesma maneira que é realizada a análise linear da rede de drenagem, para o levantamento areal são aplicados procedimentos técnicos específicos, principalmente o emprego de softwares de cartografia digital. Referentes a este tipo de análise destacam-se as seguintes variáveis: 


\section{a) Área da bacia}

É toda a área drenada limitada pelos divisores de água, conectando-se no ponto de captura, localizado na foz do canal principal. É um dos parâmetros mais importantes de uma bacia hidrográfica, pois é básico para quantificação de outros parâmetros e grandezas hidrológicas. A relação deste parâmetro com a produção de sedimentos em suspensão é fundamental, pois quanto maior a área de uma bacia hidrográfica maior será o potencial de geração de sedimentos em suspensão.

$\mathrm{A}=$ área da bacia $\left(\mathrm{km}^{2}\right)$.

\section{b) Relação das áreas médias}

Proposta inicialmente por Schumm (1956), a equação de relação de áreas é obtida dividindo-se a média das áreas das bacias dos canais de dada ordem pela média das bacias contribuintes dos canais de ordem imediatamente inferior. De acordo com o critério de ordenação de canais proposto por Strahler (1952), a área da bacia de ordem maior abrangerá também a área de todas as bacias de ordens menores que lhe são subsidiárias.

$$
\mathrm{Ra}=\frac{\mathrm{Am}_{\mathrm{u}}}{\mathrm{Am}_{\mathrm{u}-1}}
$$

Onde:

$\mathrm{Ra}=$ relação das áreas;

$\mathrm{Am}_{\mathrm{u}}=$ média das áreas contribuintes dos canais de ordem $\mathrm{u}$;

Amu-1 = média das áreas contribuintes dos canais de ordem u-1. 


\section{c) Perímetro}

É o comprimento linear do divisor topográfico, que pode ser determinado através de um curvímetro ou utilização de software de cartografia digital.

$\mathrm{P}=$ perímetro $(\mathrm{km})$.

\section{d) Fator de forma}

O fator de forma é uma variável proveniente da relação da forma da bacia com a de um retângulo, correspondendo à razão entre a largura média e o comprimento máximo da bacia (distância da foz até a cabeceira mais distante). A forma da bacia, bem como o arranjo do sistema de drenagem, pode ser influenciada por algumas características, principalmente pela geologia. Além disto, a forma da bacia pode atuar nos processos hidrológicos, ou, sobre o comportamento hidrológico da bacia.

Segundo Villela e Mattos (1975), uma bacia com um fator de forma baixo é menos sujeita as enchentes que outra de mesmo tamanho, porém com fator de forma maior. O fator de forma pode ser determinado, utilizando-se a seguinte equação:

$$
\mathrm{Kf}=\frac{\mathrm{A}}{\mathrm{L}^{2}}
$$

Sendo:

$\mathrm{Kf}=$ fator de forma;

$\mathrm{A}=$ área da bacia $\left(\mathrm{km}^{2}\right)$;

$\mathrm{L}^{2}=$ comprimento máximo da bacia $(\mathrm{km})$. 
Quanto mais próximo o resultado estiver do valor igual a 1, a forma da bacia será mais arredondada, o que pode ser indicador de maior ocorrência de enchentes, uma vez que haverá a possibilidade das chuvas se concentrarem no interior da bacia. Caso o contrário, a forma da bacia hidrográfica será mais alongada, o que representa uma redução da probabilidade de enchentes repentinas nos períodos de ocorrência de chuvas intensas.

\section{e) Densidade de drenagem}

Esta variável morfométrica relaciona o comprimento total dos rios com a área de uma determinada bacia hidrográfica; contudo, para calcular o comprimento devem ser medidos tanto os rios perenes quanto os rios intermitentes. A densidade de drenagem foi primeiramente proposta por Horton (1945) e, no Brasil, por Freitas (1952), podendo-se calculá-la a partir da seguinte fórmula:

$$
\mathrm{Dd}=\frac{\mathrm{Lt}}{\mathrm{A}}
$$

Sendo:

$\mathrm{Dd}=$ densidade de drenagem $\left(\mathrm{km} / \mathrm{km}^{2}\right)$;

$\mathrm{Lt}=$ comprimento total dos rios $(\mathrm{km})$;

$\mathrm{A}=$ área da bacia $\left(\mathrm{km}^{2}\right)$.

A densidade de drenagem representa o grau de dissecação topográfica de uma bacia hidrográfica. Quando temos uma densidade de drenagem baixa, a presença de rios é menor, devido os solos serem mais permeáveis, ocorrendo o predomínio da infiltração sobre o escoamento superficial. Quando a densidade de drenagem é mais alta, há maior número de 
rios, devido os solos serem mais impermeáveis, vindo a ocorrer o predomínio do escoamento superficial sobre a infiltração, ou seja, os valores elevados indicam áreas de pouca infiltração e melhor esculturação dos canais (CHRISTOFOLETTI, 1974).

\section{f) Coeficiente de manutenção}

Para Schumm (1956), o coeficiente de manutenção é uma variável morfométrica intimamente ligada à característica de textura da rede de drenagem. Seu emprego em estudos geomorfológicos tem a finalidade de fornecer a área mínima necessária à manutenção de um metro de canal de escoamento permanente. Para seu calculo emprega-se a seguinte fórmula:

$$
\mathrm{Cm}=\underline{\mathrm{Dd}} \times 1000
$$

Sendo:

$\mathrm{Cm}=$ coeficiente de manutenção $\left(\mathrm{m}^{2} / \mathrm{m}\right)$;

$\mathrm{Dd}=$ densidade de drenagem $\left(\mathrm{km} / \mathrm{km}^{2}\right)$;

1000 = fator de conversão. 


\subsubsection{Análise hipsométrica de bacias hidrográficas}

A análise hipsométrica de bacias hidrográficas é geralmente empregada para diferenciar o estado dos processos erosivos e desenvolvimento da rede de drenagem, uma vez que fornece uma visão sintética sobre o relevo da bacia. Este tipo de análise relaciona as altitudes, a amplitude do relevo e atributos da rede de drenagem. A seguir a descrição das principais variáveis da análise hipsométrica:

\section{a) Altitude mínima da bacia}

Refere-se à menor altitude altimétrica localizada na foz do canal principal (Alt.min).

\section{b) Altitude média da bacia}

Refere-se à altitude média da bacia, (WISLER E BRATER, 1964).

$$
\mathrm{E}=\frac{\sum \mathrm{a} * \mathrm{e}}{\mathrm{A}}
$$

$\mathrm{E}=$ altitude média;

a =área entre curvas;

e= altitude média entre duas curvas de nível consecutivas;

$\mathrm{A}=$ área da bacia.

\section{c) Altitude máxima da bacia}

Refere-se à maior altitude altimétrica localizada no interior da bacia (Alt.max). 


\section{d) Altitude mediana da bacia}

Corresponde à altitude na qual metade da área da bacia fica acima dela e metade abaixo

\section{e) Amplitude altimétrica máxima da bacia}

Refere-se à diferença altimétrica entre a altitude da foz a e altitude do ponto mais alto do divisor topográfico $(\mathrm{Hm})$.

\section{f) Relação de relevo}

A relação de relevo proposta por Schumm (1956), é uma variável que relaciona a topografia de uma bacia hidrográfica e o seu comprimento máximo. Esta variável indica a existência de uma estreita correlação com a perda de sedimentos por unidade de área, que tendem a aumentar consideravelmente com o aumento da relação de relação de relevo. Assim, quanto maior o seu valor, a tendência é que maior seja a velocidade de escoamento e menor a taxa de infiltração.

Para calculo da relação de relevo aplica-se a seguinte equação:

$$
\mathrm{Rr}=\underline{\mathrm{Hm}}
$$

Em que:

$\mathrm{Rr}=$ relação de relevo;

$\mathrm{Hm}=$ amplitude altimétrica $(\mathrm{km}) ;$

$\mathrm{L}=$ comprimento da bacia $(\mathrm{km})$. 


\section{g) Índice de rugosidade}

Definido inicialmente por Melton (1957), e posteriormente por Strahler (1964), trata-se do produto da amplitude altimétrica de uma bacia pela sua densidade de drenagem. Aplica-se a seguinte equação:

$$
\operatorname{Ir}=\mathrm{Hm} \times \mathrm{Dd}
$$

Sendo:

Ir = índice de rugosidade;

$\mathrm{Hm}=$ amplitude altimétrica $(\mathrm{m})$;

$\mathrm{Dd}=$ densidade de drenagem $(\mathrm{km} / \mathrm{km})$.

\section{h) Curva hipsográfica e de volume}

Em geomorfologia os modelos de evolução do relevo foram inicialmente propostos por Davis (1899), o mais conhecido é o "ciclo geográfico". Este modelo possibilita uma descrição qualitativa do relevo sem explicar quais teriam sido os processos que favoreceram a formação e evolução do relevo. Neste estudo é adotado um dos

procedimentos proposto por Strahler (1957), que diz respeito à geração da curva hipsográfica e de volume de uma bacia hidrográfica. A curva hipsográfica é associada aos conceitos de juventude, maturidade e senilidade de Davis (1899) (Figura 17). 

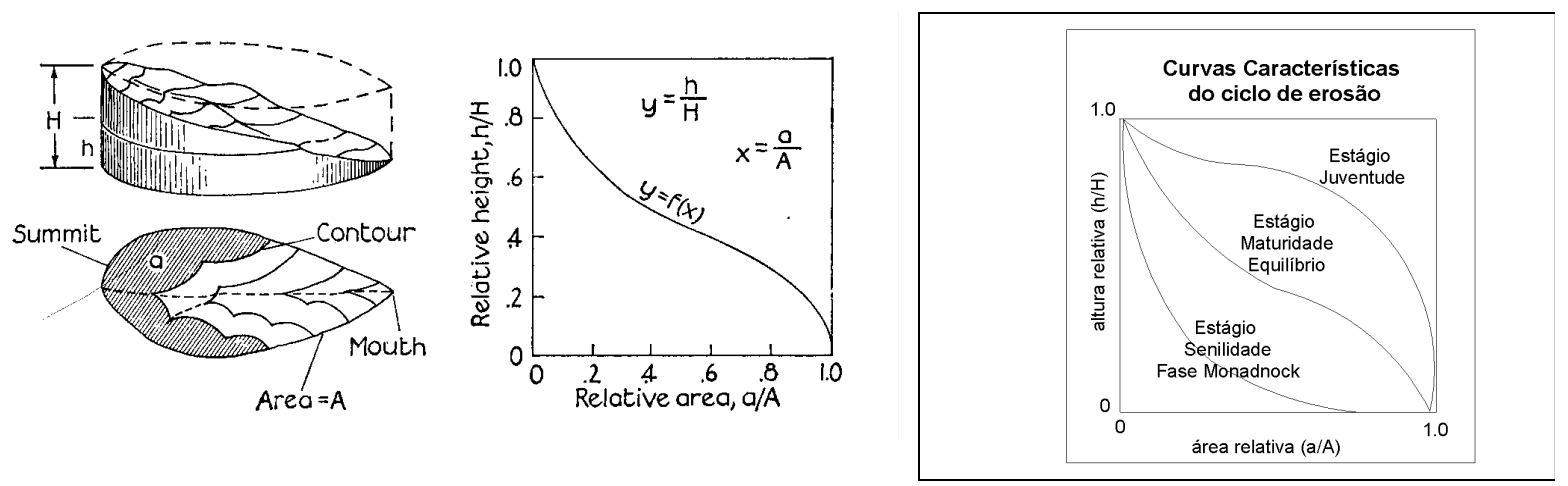

Figura 17: Curva hipsográfica, adaptado de Strahler (1957). Org: Aguiar (2009).

A curva hipsográfica é de volume são resultantes de mensurações realizadas para cada faixa altimétrica, a qual é definida de acordo com a escala de análise e procedência dos insumos a serem utilizados nos procedimentos técnicos de criação de uma curva. Na medida em que as formas de relevo desenvolvem-se por meio de processos exógenos, ocorrem mudanças na forma das curvas.

O objetivo principal de se trabalhar com estas curvas em análises geomorfológicas de bacias hidrográficas é mostrar como o volume rochoso, existente abaixo da superfície topográfica, apresenta-se distribuído desde a foz até o ponto mais alta da bacia hidrográfica (CHRISTOFOLETTI, 1981). Para Leopold et al., (1969), a curva hipsográfica representa um indicador geomorfológico extremamente útil para ser empregado em estudos que se busca descrever a evolução da paisagem das bacias hidrográficas. Sendo que, os processos de erosão continuam durante a fase de equilíbrio, o que leva a uma redução geral do relevo, uma vez que à exposição de rochas resistentes à erosão leva a um grande contraste da altitude entre as partes erodidas e não erodidas da bacia. Segundo Chorley e Morley (1959), a análise da curva hipsográfica e de volume mostra em termos quantitativos, o diminuição da superfície da bacia. Desta forma o dimensionamento volumétrico está relacionado diretamente com os processos hidrodinâmicos.

Neste estudo, o emprego das curvas hipsográficas e de volume visa analisar o potencial para desenvolvimento de processos erosivos erosão de cada bacia hidrográfica e 
com isto complementar as análises as análises hidrossedimentológicas. Para isto foram calculadas a integrais hipsométrica e a integral volumétrica. A integral hipsométrica (IH) é a relação da área das faixas altimétricas e a área total da bacia localizada abaixo da curva hipsográfica, que expressa o material existente antes do início do processo erosivo. O valor de IH é baixo para as bacias com menor potencial de erosão (curva côncava), enquanto que para as bacias com alto potencial o valor é alto (curva convexa) com a curva caindo abruptamente próximo à seção do exutório. Strahler (1952) mostra que valores de IH acima de 0.6 ou $60 \%$ é representativo para bacias em estágio de juventude, valores entre $0.6-0.35$ (60\%-35\%) para bacias em estágio de equilíbrio e abaixo de 0.35 ou $35 \%$ bacias em estágio de maturidade ou senilidade.

A integral volumétrica (IV) é a relação do volume ou porcentagem do volume total da bacia localizada abaixo da curva de volume, que expressa o material remanescente em função dos processos erosivos. A diferença entre as duas integrais (IH-IV), expressa o material removido durante os processos erosivos ocorrentes. 


\subsection{Perfil longitudinal fluvial}

O perfil longitudinal fluvial determina a declividade de um rio em função das distâncias horizontais percorridas entre cada cota altimétrica, além disto, esta variável é muito utilizada na análise geomorfológica, pois expressa a relação entre o comprimento e a altimetria pela qual um rio escoa em direção a um nível de base. Ou seja, seu significado diz respeito ao gradiente topográfico da rede de drenagem.

Se o perfil tiver forma côncava, com declividades maiores em direção à nascente são considerados em equilíbrio (ajuste entre a atuação da erosão, do transporte e da deposição). Para qualquer ponto do perfil longitudinal, há uma intrínseca relação entre o tamanho do canal e a área da bacia hidrográfica correspondente Gregory e Walley (1977).

O levantamento de diferentes perfis longitudinais é um importante procedimento para realização de análises comparativas de diferentes rios (LEOPOLD et al., 1964). Segundo Leopold et al., 1964, no canal fluvial, de montante para jusante, há: o aumento do débito, da largura e da profundidade do canal, da velocidade média das águas, do raio hidráulico, e diminuição do tamanho dos sedimentos e da competência do rio em transportá-lo, da resistência ao fluxo e da declividade.

A consistência com a qual os rios de vários tamanhos e vários ambientes fisiográficos realizam seus ajustamentos em função do aumento da descarga à jusante sugere que, existe uma tendência geralmente comum, ou, princípios físicos que governam estes ajustamentos. Por isto, o ajuste do canal está intimamente relacionado com o perfil longitudinal de um determinado rio, o qual deve ser considerado antes de buscar uma relação mais geral dos princípios físicos que condicionam os gradientes e formas dos rios (LEOPOLD et al., 1964).

De acordo com Leopold et al., (1964), as variáveis que influenciam nos ajustes morfológicos dos padrões dos canais são: profundidade do canal, largura, velocidade do fluxo, carga e tamanho dos sedimentos, declividade do canal, descarga de sedimentos, e 
irregularidades do leito. Caso haja qualquer mudança em uma dessas variáveis, se processará um novo ajuste das formas e na dinâmica dos rios. Desta forma o levantamento do perfil longitudinal é um importante procedimento para o entendimento dos aspectos relacionados aos ajustes dos processos geomorfológicos.

As rupturas de declive ou mudanças na forma do perfil longitudinal indicam processos de ajuste que atuam no equilíbrio das formas e transporte de materiais, tais mudanças estão associadas a corredeiras, cachoeiras, saltos, áreas de confluência de tributários e evidências de captura fluvial. Segundo Hack (1957), as rupturas estão relacionadas á mudança da litologia, ou rápido aumento da descarga liquida decorrente da confluência de tributários. Dentre os objetivos desta pesquisa o perfil longitudinal subsidia a análise das bacias hidrográficas em relação a capacidade de estocagem, mobilização ou liberação de sedimentos suspensos em direção ao rio Paraná, consequentemente em direção ao reservatório de Itaipu. 


\subsection{Análises hidrossedimentológicas}

Os estudos hidrossedimentológicos de bacias hidrográficas compreendem basicamente na utilização de dados coletados por observação de campo e testes de laboratórios. Este tipo de estudo é realizado com base no levantamento de algumas variáveis hidrológicas e sedimentológicas.

As medições de descarga líquida ou vazão são os principais insumos para os estudos hidrológicos e de geomorfologia fluvial. A comparação de diferentes seções transversais ao longo do comprimento dos rios sob uma determinada condição de fluxo, ou frequência de fluxo, é de grande importância para entendimento da dinâmica fluvial e condição de equilíbrio. Neste sentido a descarga liquida é o parâmetro mais significativo para qualquer discussão a respeito da morfologia do canal de um rio, mais especificamente para sua forma e manutenção.

Conforme aumenta o nível de água, também aumenta a velocidade do fluxo, caracterizando uma correlação direta entre ambas as variáveis. Assim, muitos dados disponibilizados a partir das médias anuais da descarga, proporcionam uma medida conveniente para comparação do fluxo de diferentes rios (LEOPOLD et al.,1964).

Leopold et al., (1964), consideram que o aumento da descarga de montante para jusante de um trecho de drenagem poderá influenciar na modificação da forma, ou seja, o canal fluvial pode tornar-se crescentemente mais amplo, preservando a profundidade e o fluxo constantes, ou, estes podem aumentar a velocidade, preservando a profundidade e comprimento constante. Cada combinação irá exigir mudanças na declividade do canal, dependente da mudança de fluxo e resistência litológica à jusante.

Referente o aporte de sedimentos em suspensão de um rio, este é resultado das transformações das variáveis de estado (ex: solos, litologia, cobertura vegetal, relevo) em função das variáveis de transformação (ex: erosão, transporte, débito pluvial, vazão). Os sedimentos em suspensão transportados pelos rios são classificados de acordo com suas 
características granulométricas, geralmente são classificadas como areia, siltes, argila e pedregulho. A medição da ocorrência de tais partículas em suspensão no meio aquoso é definida em termos volumétricos como sendo a concentração de sedimentos em suspensão por litro de água Css (mg/l).

A variabilidade da concentração de sedimentos em suspensão e a descarga líquida de uma seção do canal fluvial são influenciadas por diferentes intensidades e distribuição das precipitações, além da extensão do percurso superficial das bacias hidrográficas, capacidade de armazenamento e mobilização dos sedimentos em suspensão e taxa de sedimentação (WILLIAMS 1989).

Reid et al., (1997) descreve que são inúmeros os fatores que influenciam a relação da concentração de sedimentos em suspensão e descarga líquida. Entre os principais fatores destaca a intensidade da chuva, a variação temporal do uso do solo e o gradiente topográfico da bacia hidrográfica; além da temperatura antecedente e as condições de umidade e descarga que influenciam na quantidade de sedimento a ser fornecida por erosão das vertentes e do canal principal.

Segundo Allen (1997), o transporte de sedimentos e materiais solúveis, que corresponde ao transporte fluvial de massa da bacia de hidrográfica, geralmente é o fator dominante no balanço de massa de uma bacia hidrográfica, onde a maior parte será obtida por meio do intemperismo. O total de materiais transportados pelo rio pode ser determinado de maneira satisfatória por meio da medição da concentração de materiais depositados no leito do canal, ou, suspensos em função do fluxo turbulento da água.

A relação do resultado da concentração de sedimentos em suspensão e a descarga líquida de uma seção transversal de um rio em função do tempo foi proposta por Carvalho (1994), para estimar o transporte total de sedimentos em suspensão, ou, descarga sólida de sedimentos em suspensão através da seguinte equação:

$$
\text { Qss }=0,08640 \times \mathrm{Q} \times \text { Css }
$$


Sendo:

Qss = descarga sólida de sedimentos em suspensão (t/dia);

$\mathrm{Q}=$ descarga líquida $\left(\mathrm{m}^{3} / \mathrm{s}\right)$;

$\mathrm{Cs}=$ concentração de sedimentos em suspensão $(\mathrm{mg} / \mathrm{l})$.

O valor 0,08640 da equação citada anteriormente é o resultado da conversão entre as unidades, tonelada métrica dia (t.dia), metros cúbicos por segundo $\left(\mathrm{m}^{3} / \mathrm{s}\right)$ e miligramas por litro (mg/l), para tonelada métrica por segundo (t.s). Para melhor entendimento desta conversão é sugerido o seguinte raciocínio: O tempo de 1 dia equivale a $8,64 * 10^{2}$ segundos. A vazão de 1 metro cúbico por segundo equivale $10^{3}$ litros. A concentração de sedimentos em suspensão referente a 1 miligrama por litro corresponde a $10^{-9}$ toneladas. Sendo assim, o tempo de 24 horas em segundos, a vazão de $1 \mathrm{~m}^{3} / \mathrm{s}$ e concentração de $1 \mathrm{mg} / 1$ de sedimentos em suspensão corresponderá a massa total em função do tempo em segundos (t.s), portanto:

(Tempo x Vazão x Concentração= Massa. Tempo)

$\underline{\left(8,64 * 10^{2}\right) \text { segundos } *\left(10^{3}\right) \text { litros } *\left(10^{-9}\right) \text { toneladas }=8,64 * 10^{-4} \text { toneladas a cada segundo ou }}$ $\underline{0,0864(\mathrm{t} / \mathrm{s})}$

\section{$\therefore$ Qss $(\mathrm{t} / \mathrm{dia})=0,0864 * \mathrm{Q} *$ Css}

A descarga sólida em suspensão inclui as partículas de granulometria reduzida (silte e argila) que por serem pequenas se conservam em suspensão pelo fluxo turbulento. Segundo Ward e Trimble (1995) a descarga sólida em suspensão pode representar mais de $90 \%$ do material total transportado no canal fluvial. 
A análise dos sedimentos em suspensão é um dos indicadores para a caracterização dos fluxos de materiais de bacias hidrográficas tendo em vista as modificações decorrentes dos processos do uso e manejo do solo. Ao considerar a bacia hidrográfica como uma unidade geomórfica, os fluxos de matéria e energia estão correlacionados com a área da bacia. Portanto, a área da bacia de contribuição (A), em relação a uma estação de monitoramento, juntamente com a descarga sólida de sedimentos em suspensão (Qss) possibilita estimar a produção especifica diária de sedimentos em suspensão (Pss) por área (t/km²/dia), para isto Carvalho (1994), destaca a utilização da seguinte equação:

$$
\text { Pss }=\frac{\text { Qss }}{\mathrm{A}}
$$

Pss $=$ produção específica da produção de sedimentos em suspensão $\left(\mathrm{t} / \mathrm{km}^{2} / \mathrm{dia}\right)$; Qss = descarga sólida dos sedimentos em suspensão (t/dia);

$\mathrm{A}=$ área da bacia $\left(\mathrm{km}^{2}\right)$.

Neste estudo, a comparação da Pss das bacias hidrográficas em questão resulta numa importante fonte de conhecimento da variação ao longo do tempo das vazões e produção de sedimentos em suspensão, além possibilitar análises das influências dos aspectos hidrogeomorfológicos diante o potencial das fontes geradoras. 


\subsection{Geoprocessamento aplicado a estudos de bacias hidrográficas}

Segundo Câmara e Medeiros (1998), o geoprocessamento constitui o emprego de técnicas matemáticas e computacionais para o tratamento de informação geográfica, influenciando de maneira crescente as áreas de cartografia, análise de recursos naturais, transportes, comunicações, energia e planejamento urbano e regional. Os autores mencionam que os sistemas de informações geográficas (SIGs), considerados ferramentas computacionais de geoprocessamento, permitem realizar análises complexas, ao integrar dados de diversas fontes e criar bancos de dados georreferenciados, possibilitando ainda a produção de documentos cartográficos. Para Câmara (1993), o banco de dados geográficos é o repositório de dados do SIG, sendo que este é responsável pelo armazenamento e recuperação de atributos espaciais e não-espaciais. Os SIGs armazenam a geometria e os atributos dos dados que estão georreferenciados - localizados na superfície terrestre e representados numa projeção cartográfica. Os dados tratados em geoprocessamento têm como principal característica a diversidade de fontes geradoras e de formatos apresentados.

Nos estudos de bacias hidrográficas os SIGs são amplamente utilizados para fins de levantamento de informações morfométricas, cruzamento de mapas, armazenamento e publicação de informações. Dentre outras definições de SIG, Burrough (1986), o define como um poderoso conjunto de ferramentas de entrada de dados, armazenamento, recuperação e manipulação, modelagem, exibição de dados e publicação de mapas. Os dados espaciais ou geográficos representam fenômenos do mundo real segundo aspectos de localização e temporalidade.

Para caracterização de bacias hidrográficas, a imprecisão quanto às fontes de dados hidrológicos, procedimentos para utilização de softwares e origem dos insumos cartográficos, são aspectos que acabam prejudicando o desenvolvimento de uma pesquisa. 
Norton (1990), ao considerar esta questão, identificou a importância da organização das informações da área de estudo em um banco de dados de geográficos.

No Brasil a utilização do geoprocessamento teve início efetivo a partir de 1982, quando houve um impulso na expansão dos conhecimentos sobre este tema, através de softwares nacionais, entre estes, destacam-se o Sistema de Análise Geoambiental - SAGA (UFRJ), e o Sistema de tratamento de imagens/Sistema Geográfico de informações SITM/SGI criado pelo INPE. O SITIM foi precursor do SPRING (Sistema de processamento de informações geográficas). Atualmente existem inúmeros softwares gratuitos e proprietários para processamento de dados geográficos. Entre os softwares proprietários o ArcGis da empresa ESRI (Environmental Systems Research Institute), e o Erdas Imagine possibilitam inúmeras funcionalidades de análises.

O ArcGis Desktop é um conjunto de softwares que funciona em computadores padrão e são usados para criar, importar, editar, buscar, mapear, analisar e publicar informações geográficas. Quatro softwares compõem o conjunto ArcGis Desktop; cada um acrescenta um nível superior de funcionalidades, são eles: ArcReader, ArcView, ArcEditor, ArcInfo. Todos os produtos ArcGis Desktop compartilham a mesma arquitetura, desta forma, usuários de quaisquer um dos softwares ArcGis Desktop podem compartilhar seus trabalhos entre si. Documentos de mapas, dados, símbolos, definições de apresentação dos temas, relatórios, metadados, modelos de geoprocessamento, interfaces e ferramentas customizadas entre outros, podem ser distribuídas livremente entre os usuários destes softwares.

Para aplicações de SIG em estudos de bacias hidrográficas a ESRI disponibiliza gratuitamente a extensão ArcHidro e scripts específicos para delimitação de bacias, extração da rede de drenagem, e tributação dos elementos hidrográficos. Quanto ao software Erdas Imagine, este possibilita a utilização de um amplo conjunto de ferramentas para processamento digital de MDE e imagens multiespectrais provenientes de satélites de 
sensoriamento remoto. O sensoriamento remoto é uma ciência que dispõe de inúmeras técnicas para obter informações acerca de um objeto, área ou fenômeno da superfície terrestre, por meio da análise de dados adquiridos por um dispositivo, por exemplo, sensores a bordo de satélites (LILLESAND; KIEFER 1994). Neste estudo o sensoriamento remoto é aplicado para identificar as diferenças da intensidade da cor da água nas desembocaduras das bacias hidrográficas em um mesmo recorte temporal.

No contexto das pesquisas voltadas a análise de bacias hidrográficas a disponibilidade de dados de sensoriamento remoto gratuitos vem ocasionando o aumento de publicações de pesquisas e instrumentalização dos pesquisadores, principalmente a utilização de modelos digitais de elevação (MDE) provenientes da missão SRTM e imagens de satélites. Um MDE pode ser definido como uma representação espacial de terminada superfície a partir de pontos, armazenado em formato matricial, que descrevem a topografia do terreno ou a elevação tridimensional de uma grade de dados a intervalos regulares ou irregulares (MONTGOMERY, 2003).

Os dados SRTM foram coletados por meio do instrumento Spaceborne Imaging Radar-C/X-Band Synthetic Aperture Radar (SIR-C/X-SAR), a bordo do ônibus espacial Endeavour. A Endeavour foi lançada no Kennedy Space Center (KSC) no dia 11 de fevereiro do ano de 2002. A altitude de sobrevôo foi algo próximo a altitude $233 \mathrm{~km}$, e inclinação orbital de $57^{\circ}$. Com esta geometria de captura de dados a missão realizou inúmeras órbitas ao redor do planeta Terra durante 11 dias. O sobrevôo foi concluído com a coleta de $12 \mathrm{~TB}$ de dados que são processados para a geração de modelos de elevação. (FARR ; KOBRICK, 2000)

Segundo Grohmann et al., (2008) a utilização do MDE SRTM em estudo geomorfológicos tem permitido o cálculo de variáveis associadas ao relevo com rapidez e precisão. O crescimento da capacidade de processamento e armazenamento de dados dos computadores aliado a evolução dos sistemas de informações geográficas (SIG) encontra-se 
em um estágio no qual é possível trabalhar em extensas áreas com alta resolução espacial, sem perda significativa do tempo de processamento envolvido.

Pinheiro (2006) apresenta uma análise comparativa entre os dados altimétricos derivados do MDE SRTM e de cartas topográficas da escala de 1:50.000 da Diretoria do Serviço Geográfico (DSG) com pontos de controle adquiridos com aparelho de captura de sinal GPS (Global Position System), os quais foram corrigidos pelo método diferencial. O estudo foi realizado no Planalto das Araucárias, nordeste do Rio Grande do Sul, Brasil, na área do Centro de Pesquisas e Conservação da Natureza PRÓ-MATA. As análises dos MDE foram realizadas através de testes estatísticos e gráficos. O MDE SRTM apresentou melhor precisão cartográfica que o MDE da DSG quando comparado com dados obtidos pelo GPS. Os erros médios quadráticos dos MDE SRTM e DSG foram, respectivamente, 7,0m e 26,8m, isto demonstra que o MDE SRTM possui boa precisão.

De acordo com estes resultados das pesquisas anteriormente citadas, a resolução de 90m do MDE SRTM pode ser considerada razoável para análises em escalas pequenas ou médias, embora não apropriado para ser aplicado em estudos de detalhe. Grohmann et al., (2008), descreve que a interpolação do MDE SRTM por meio do processaemtno digital de imagens (PDI) não irá aumentar o nível de detalhe do modelo resultante, porém resultará em uma superfície com coerência de suas propriedades angulares, fator importante em análises morfométricas.

Desta forma, neste estudo o objetivo de se usar processamento digital de imagens (PDI) foi melhorar o aspecto visual de certas feições estruturais e fornecer subsídios para as análises hidrogeomorfológicas. Também foi possível por meio do PDI reamostrar a resolução espacial do MDE SRTM, além de processar imagens multiespectrais a fim de relacionar a cor dos pixels referente a água que flui dos rios Iguatemi e Piquiri num mesmo recorte temporal. E com isto verificar a variabilidade hidrossedimentológica por meio da análise comparativa da Pss de cada bacia hidrográfica no período de coleta das imagens do satélite QuickBird. 


\subsection{Procedimentos técnicos para desenvolvimento das analises hidrogeomorfológicas e hidrossedimentológicas}

No intuito de propor a sistematização dos procedimentos para análise das bacias hidrográficas contribuintes do reservatório de Itaipu foram definidas 4 etapas (Figura 18).

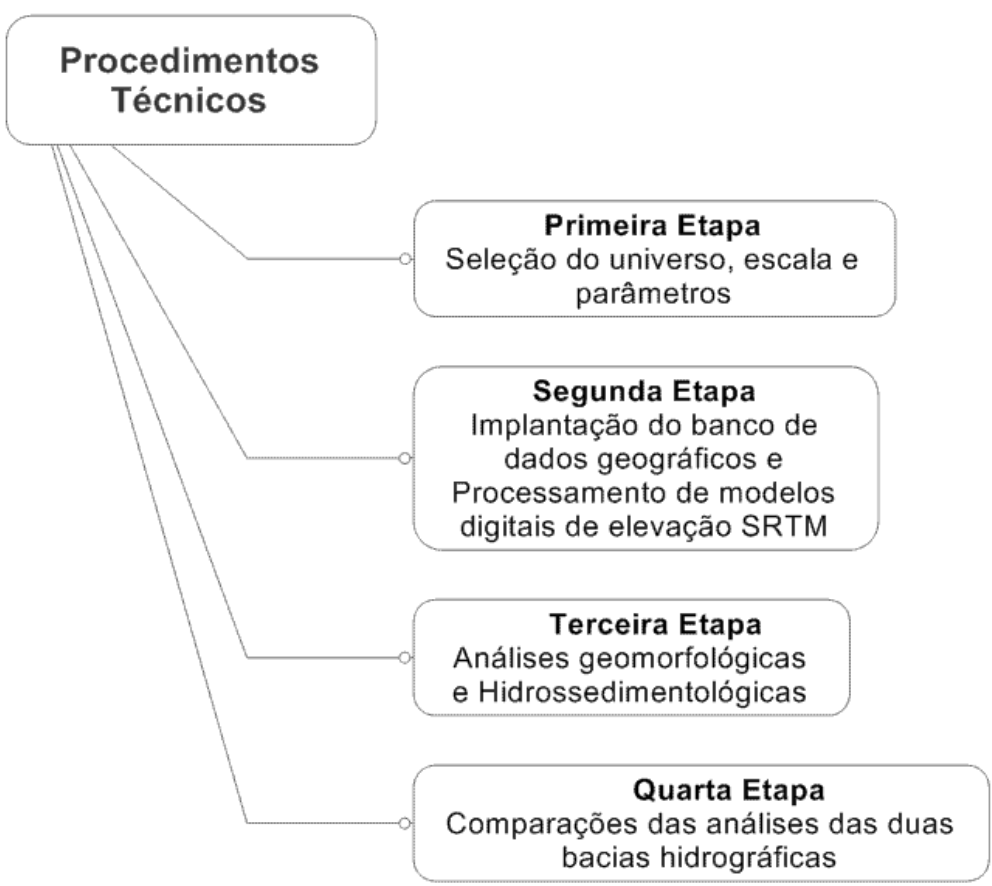

Figura 18: Procedimentos técnicos. Org: Aguiar (2009).

- Primeira Etapa - Seleção do universo da pesquisa, escala de análise e parâmetros.

Esta etapa é fundamental em qualquer estudo geomorfológico, sendo que neste estudo o universo da pesquisa corresponde ao conjunto maior do sistema, ou seja, a bacia hidrográfica do rio Paraná e seus sub-sistemas. As bacias hidrográficas do rio Iguatemi e Piquiri são sub-sistemas do rio Paraná que exercem influências direta sob o reservatório de Itaipu. Vários aspectos foram considerados neste estudo para composição dos sistemas, 
entre estes a noção de escala de análise e os parâmetros específicos (morfométricos, hidrossedimentológicos) utilizados para comparação das bacias hidrográficas.

Tendo como base metodológica a teoria geral dos sistemas, o desenvolvimento da pesquisa estabelece as bacias hidrográficas escolhidas como unidades de análises hidrogeomorfológicas e hidrossedimentológicas. Estas unidades são delimitadas pelos divisores de águas e tem a função de captar e transportar, por meio do fluxo de água, os sedimentos produzidos em sua área, os quais são mensurados pontualmente ao longo da rede de drenagem. Neste sentido a noção de escala em geomorfologia foi fundamental para construção do cenário das análises realizadas neste estudo. Em geomorfologia a noção de escala pode ser considerada como um dos princípios ou metas mais relevantes, portanto parte fundamental do conjunto de orientações metodológicas gerais. A necessidade em se elaborar abordagens com escalas espaço-temporais diversas e, consequentemente, de se abordarem fenômenos de dimensões variadas e interrelacionados é assumido hà muito tempo em geomorfologia e sua origem está ligada tanto à necessidade taxonômica quanto à busca da explicação (genética, processual, cronológica) sob estas várias perspectivas (RODRIGUES 1997).

Para Cruz (1985) os estudos geomorfológicos não podem prescindir do enfoque metodológico relativo à escala espaço-tempo, uma vez que os processos intempéricos, pedogênicos e geomórficos, estão interrelacionados. Portanto, o estudo dos processos geomorfológicos e o enquadramento em escalas específicas constituem uma questão de método em geomorfologia que tem intenção de fornecer ao pesquisador um caminho de clareza e objetividade para seus estudos de modo que seus propósitos sejam alcançados.

Neste estudo foi levada em consideração a proposta de Queiroz Filho (2005), na qual, o uso da escala em pesquisas geomorfológicas está condicionado a três diferentes abordagens, a cartográfica, a de análise e a de fenômeno. Em relação à escala cartográfica sua adoção está diretamente relacionada com as características dos produtos cartográficos disponíveis, principalmente o MDE SRTM que é utilizado para levantamento de dados 
morfométricos. Quanto a escala de análise, a mesma está relacionada com a localização das bacias hidrográficas e desembocaduras dos rios Iguatemi-MS e Piquiri-PR, as quais estão próximas do início do reservatório de Itaipu.

Em relação à escala dos fenômenos, neste estudo as medições hidrossedimentométricas são representadas pontualmente nas bacias e os parâmetros monitorados permitem a representação da distribuição da ocorrência do fenômeno de forma concentrada, ou seja, a ocorrência de um padrão está correlacionada a uma ocorrência maior. Os dados hidrossedimentológicos utilizados são provenientes dos postos de monitoramento 64830000 - (Balsa Santa Maria - rio Piquiri- PR) e 64725000 (Estrada Iguatemi - rio Iguatemi - MS), cujas mensurações foram realizadas pela Itaipu Binacional no período de 01/01/2002 a 31/12/2006.

Os parâmetros adotados para desenvolvimento deste estudo foram aqueles relacionados a morfometria da rede de drenagem e das bacias hidrográficas, assim como os parâmetros hidrossedimentológicos, principalmente a produção especifica de sedimentos em suspensão (Pss).

Portanto, este estudo contou com a utilização de materiais provenientes de diversas fontes, a fim de se efetivar as análises hidrogeomorfológicas e hidrossedimentológicas para comparação das bacias hidrográficas contribuintes do reservatório de Itaipu. Os materiais utilizados para desenvolvimento da pesquisa foram os seguintes:

- Modelo digital de elevação MDE SRTM proveniente da CGIAR-CSI (Consultative Group on International Agricultural Research - Consortium for Spatial Information) - http://srtm.csi.cgiar.org/ ;

- Produtos cartográficos da Mineropar, RADAM e Agência Nacional de Águas 
- Série histórica de dados de dados hidrossedimentológicos disponibilizados pela Itaipu Binacional. Para contar com estes dados, foi realizado uma visita técnica ao setor de hidrologia e meio ambiente desta entidade no dia 30/07/2007.

- Segunda Etapa - Implantação do banco de dados geográficos e Processamento de modelos digitais de elevação SRTM

Para organizar os dados disponíveis para desenvolvimento da pesquisa, foi realizada a implantação de um banco de dados geográficos com relacionamento espacial entre as variáveis de cada bacia hidrográfica. O software ArcGis 9.2 possibilitou a interface para a execução de consultas no banco de dados, de acordo com as estruturas de relacionamento entre as variáveis geográficas disponíveis no modelo de dados, como também a extração de informações referentes as condições topográficas das bacias hidrográficas de forma a auxiliar as análises geomorfológicas.

Uma alternativa viável diante o uso do MDE SRTM consiste em interpolar os dados originais para uma resolução 2 vezes menor que a original. Para isto o software Erdas Imagine disponibiliza inúmeras ferramentas para execução da interpolação. Para que o MDE atenda ou que se aproxime da demanda técnica exigida são realizados inúmeros procedimentos apresentados no fluxograma de processos a seguir (Figura 19). 


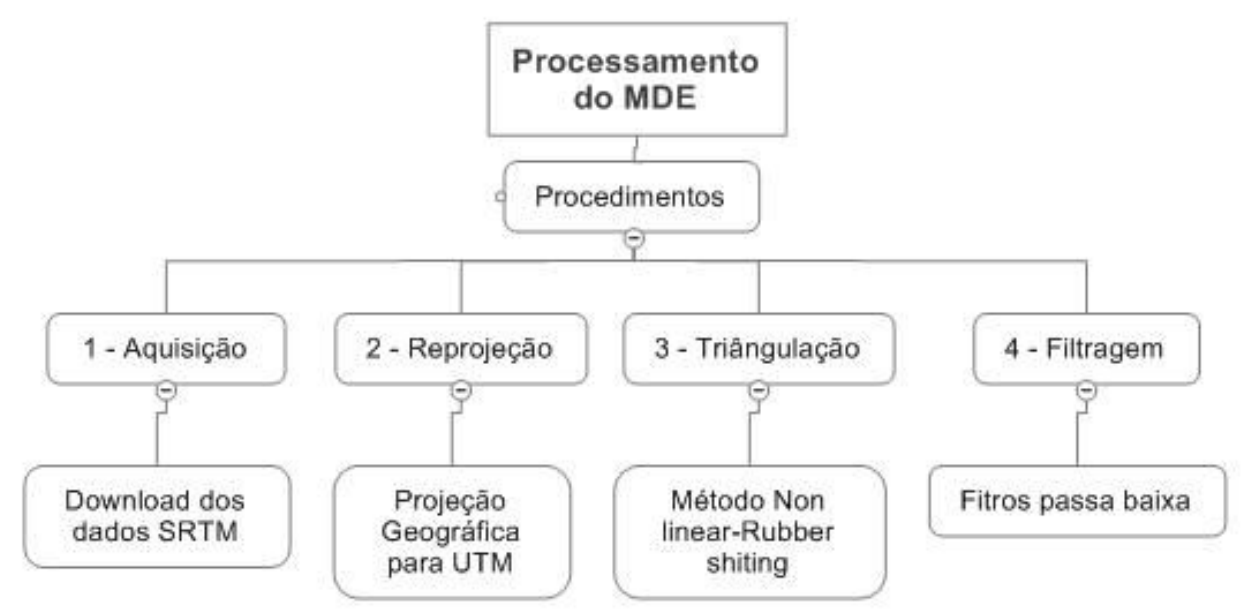

Figura 19: Fluxograma de procedimentos para processamento digital dos MDE SRTM. Org: Aguiar (2009).

Após a aquisição dos dados SRTM, a entrada dos dados altimétricos foram reprojetados para projeção UTM (Universal Transversa de Mercator) com sistema de referência - datum SAD 69 (South americam Datum). Em seguida estes dados são processados por meio do software Erdas Imagine. O módulo utilizado para triangulação foi Create Surface, e o método escolhido foi o Non-linear Rubber Sheeting.

Após a triangulação e reprojeção foi realizado duas reamostragens do MDE por meio de filtros do tipo "passa baixa" com Kernel de dimensões 3x3. A seguir é apresentada a comparação visual das curvas de níveis extraídas do MDE SRTM antes e depois dos procedimentos descritos anteriormente. (Figura 20). 


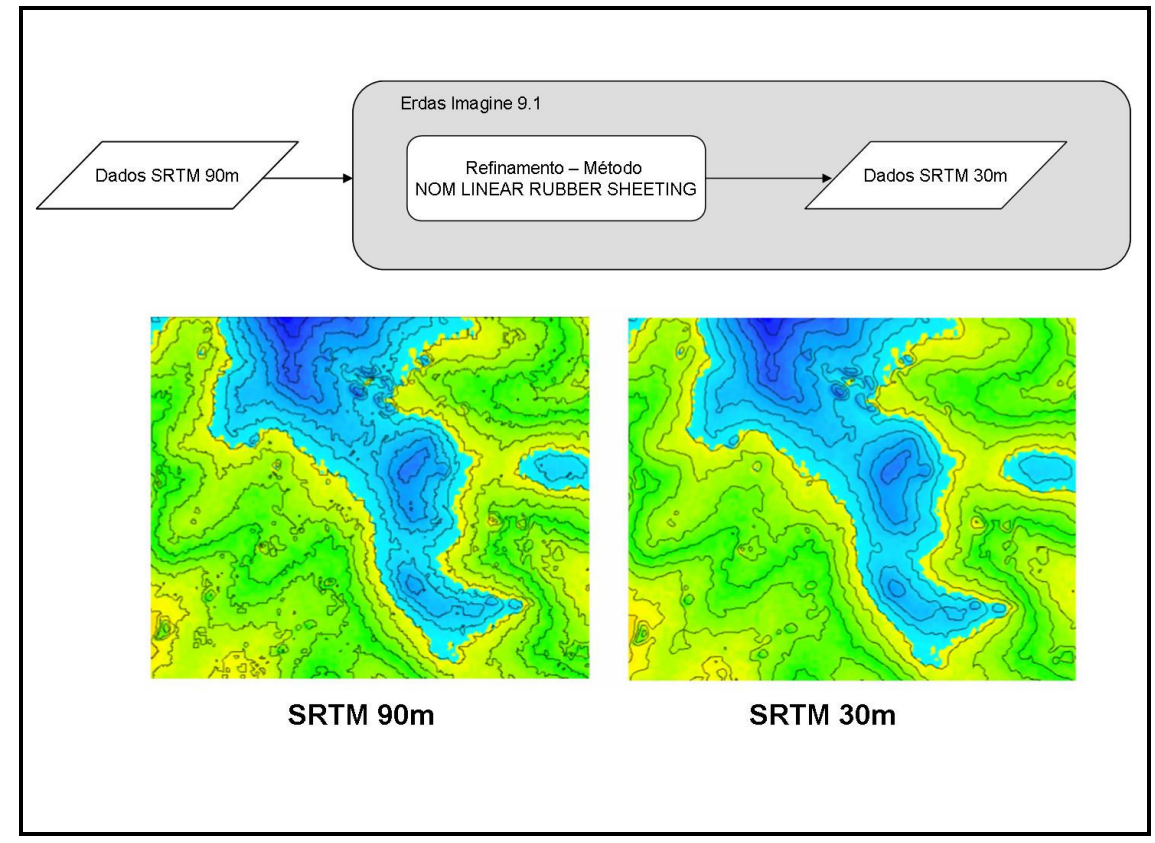

Figura 20: Resultado do refinamento do MDE SRTM. Org: Aguiar (2009).

Após esta etapa de refinamento dos dados altimétricos, foram executados os procedimentos para geração dos mapas referente ao relevo das bacias hidrográficas. Foram produzidas as seguintes representações:

\section{a) Relevo realçado}

Esta representação do relevo é apresentada sob a forma matricial com a composição colorida de três bandas direcionada ao canhão de cores - RGB red-green-blue com a finalidade de mostrar o relevo tridimensionalmente Para geração do relevo realçado foi utilizado o comando "painted relief" do software Erdas Imagine (Figura 21).

Os parâmetros utilizados foram os seguintes:

- Utilização do gradiente estatístico da imagem (mínimo e máximo)

- Unidade da elevação do MDE em metros 
- Fator de exagero vertical igual a 1

- Ângulo de azimute solar igual a $345^{\circ}$

- Ângulo de elevação do Sol igual a $45^{\circ}$

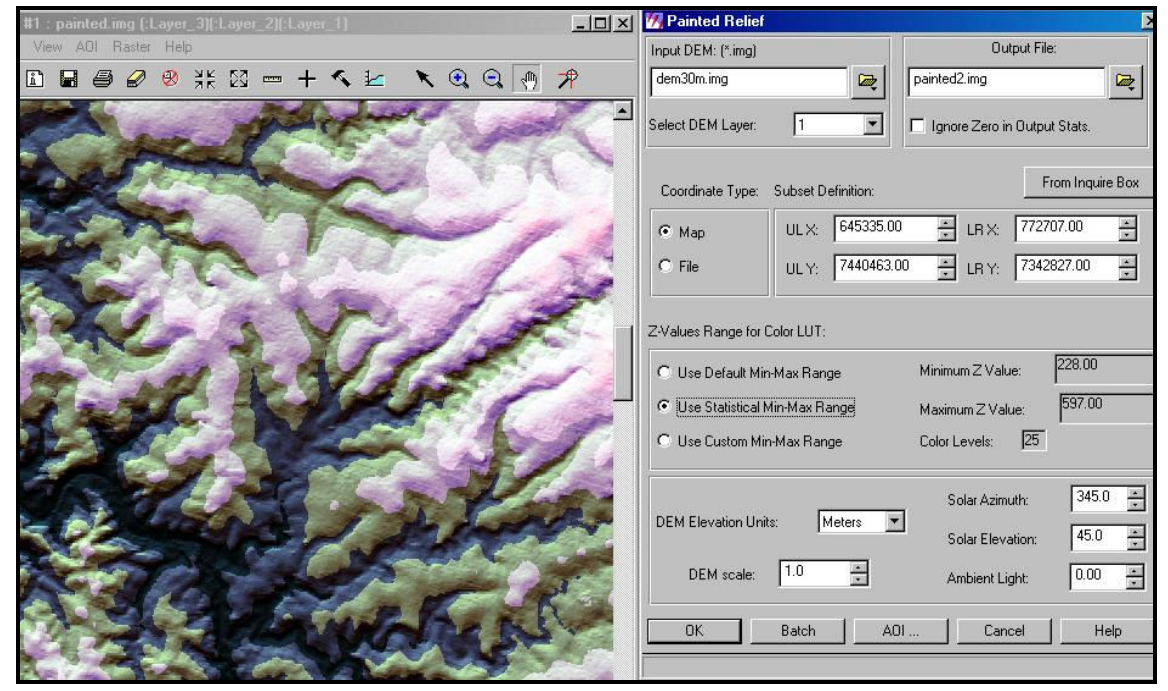

Figura 21: Relevo realçado produzido no Erdas Imagine por meio da função "Painted Relief". Org: Aguiar (2009).

\section{b) Declividade em porcentagem}

Utilizando o MDE SRTM e o comando "Slope", foi criado um arquivo raster com resolução espacial 30×30m para cada bacia, tendo como valor de pixels a declividade do relevo em porcentagem, ou seja, a representação da tg $\alpha$ (tangente de um ângulo) x 100, sendo 45 graus igual a 100\% (Figura 22). Os intervalos de declividades adotados foram adaptados tendo como referência a chave de classificação proposta por Emprapa (1995) (Tabela 1). 


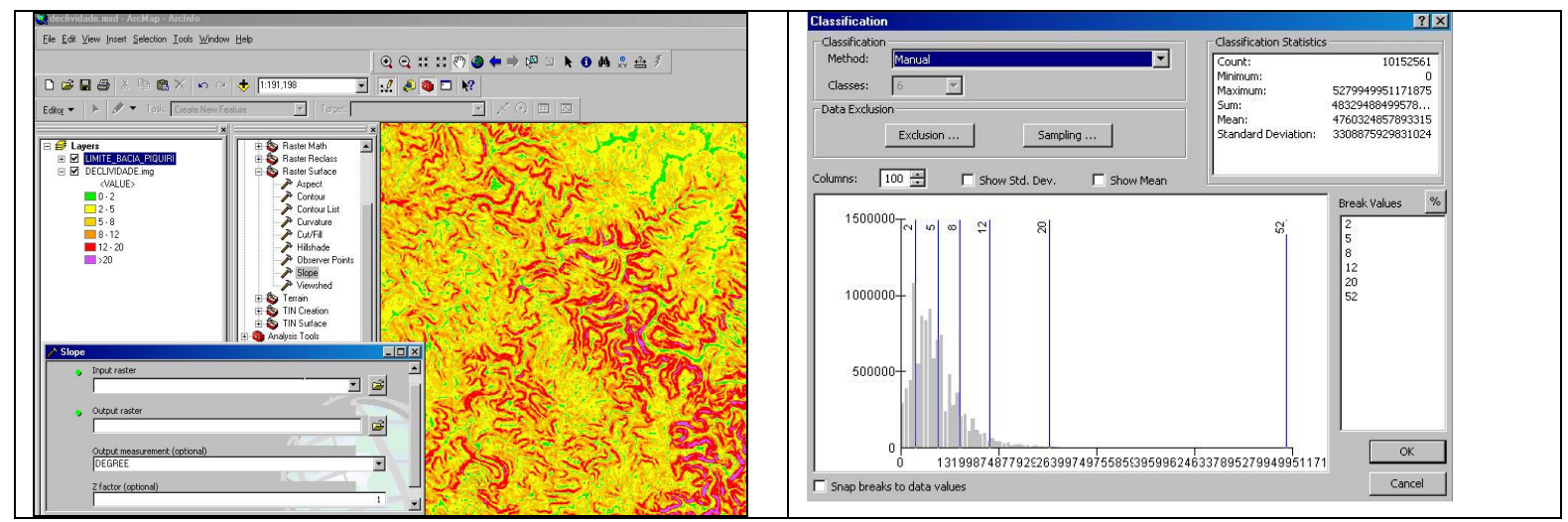

Figura 22: Geração do mapa de declividade em classes de porcentagem por meio do software ArcGis 9.2. Org: Aguiar (2009).

Tabela 1: Porcentagens das classes de declividade e tipos de relevo de acordo com Embrapa (1995).

\begin{tabular}{c|c}
\hline Classe \% & Relevo \\
\hline $0-3$ & Plano \\
$3-6$ & Plano a suave ondulado \\
$6-12$ & Suave ondulado a ondulado \\
$12-20$ & Ondulado a forte ondulado \\
$20-40$ & Forte ondulado a montanhoso \\
$>40$ & Montanhoso \\
\hline
\end{tabular}

Com base na forma do relevo as declividades foram reclassificadas em classes descritivas de alta média e baixa declividade. A classe de alta declividade corresponde aos valores do intervalo $20-40 \%$ e $>40 \%$ (forte ondulado a montanhoso, montanhoso), classe média são os valores de 6-12\% e 3-6 \% (suave ondulado a ondulado, ondulado a forte ondulado), e a classe de baixa declividade foram consideradas as declividades de $3-6 \%$ e $<3 \%$ (plano a suave ondulado, plano).

\section{c) Hipsometria}

Com objetivo de representar as relações existentes em determinada unidade horizontal do espaço e à sua distribuição em relação às cotas altimétricas foram gerados mapas hipsométricos das bacias hidrográficas. Trata-se de um procedimento técnico que 
indica a proporção ocupada por determinada área da superfície terrestre em relação às variações altimétricas. Ou seja, o mapa hipsométrico permite uma visualização dos compartimentos topográficos em intervalos de classes e possibilita a geração da curva hipsográfica. Para confecção dos mapas foi utilizado o MDE SRTM e o software ArcGis9.2, e intervalo de classes definido foi de 50m (Figura 23).

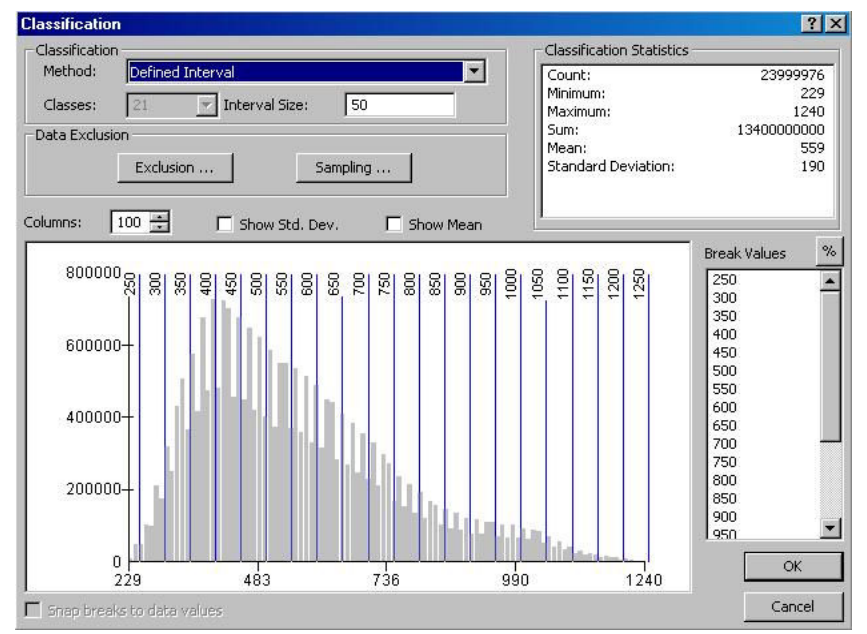

Figura 23. Geração do mapa hipsométrico por meio do software ArcGis 9.2. Org: Aguiar (2009).

- Terceira Etapa - Modelagem hidrológica e análises geomorfológicas

Nesta etapa utilizou-se o software ArcView 9.2 juntamente com o conjunto de ferramentas "ArcHidro e Watershed Delineation for ArcGis 9.x," para processamento do MDE SRTM e criação da rede de drenagem e delimitação de bacias hidrográficas de acordo com os parâmetros de entrada (Figura 24). O exutório foi definido levando se em consideração a localização dos postos de monitoramento hidrossedimentométrico utilizados identificados como limite da cota mínima de cada bacia. 


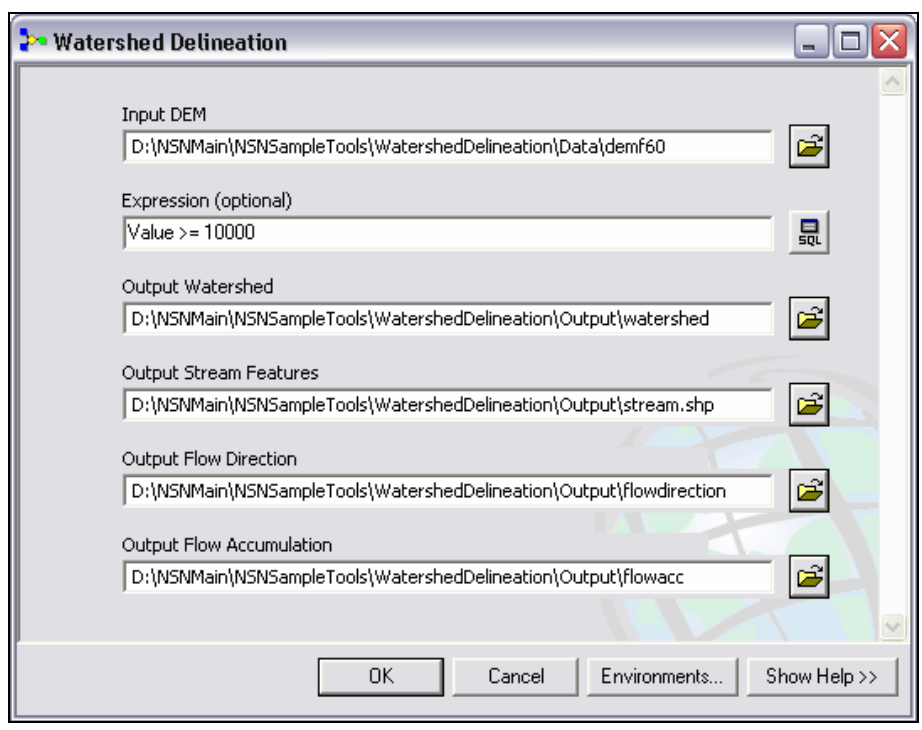

Figura 24: Interface dos parâmetros de entrada para emprego do Watershed Delineation.

Após o procedimento de extração dos limites da bacia e a rede de drenagem utilizou-se o aplicativo Hidroflow para inferência de fluxo e hierarquia dos canais pelo método proposto por Strahler (1952). O Hydroflow trabalha com arquivos shapefiles da rede de drenagem (linhas), limite da bacia (polígonos) (Figura 25).

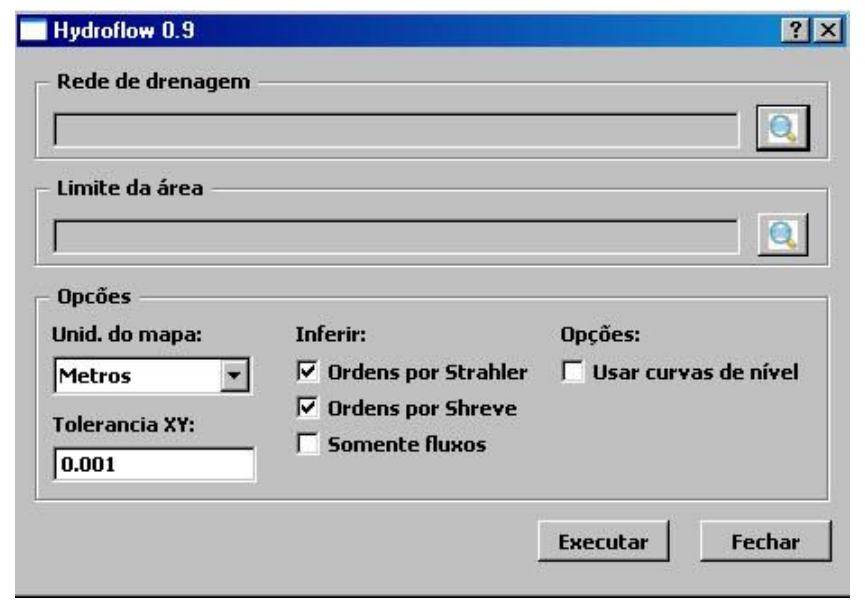

Figura 25: Interface de parâmetros de entrada para inferência de fluxo e hierarquização da rede de drenagem.

Segundo Christofoletti (1974), definir a hierarquia da rede fluvial consiste no estabelecimento e classificação de determinado curso de água no conjunto total de uma 
bacia hidrográfica. Ainda segundo o autor, este procedimento é realizado sempre que se busca facilitar e tornar mais objetivos os estudos morfométricos (análise linear, areal e hipsométrica). A seguir a descrição das variáveis de hierarquização da rede de drenagem e da bacia hidrográfica (Quadro 1,2).

Quadro 1: Variáveis de hierarquização da rede de drenagem.

\begin{tabular}{|l|c|l|c|c|}
\hline $\begin{array}{l}\text { Variáveis da } \\
\text { hierarquização }\end{array}$ & Símbolo & \multicolumn{1}{|c|}{ Descrição } & Fórmula & Fonte \\
\hline Ordem de canais & $\mathrm{u}$ & $\begin{array}{l}\text { Ordenação das ordens de canais de } \\
\text { uma bacia. }\end{array}$ & $\begin{array}{c}\text { Strahler } \\
(1952)\end{array}$ \\
\hline $\begin{array}{l}\text { Número de canais de cada } \\
\text { ordem }\end{array}$ & $\mathrm{N}_{\mathrm{u}}$ & $\begin{array}{l}\text { Resultado da contagem de rios de } \\
\text { determinada ordem de cada bacia }\end{array}$ & $\begin{array}{c}\text {------------ } \\
\text { Númerahler } \\
(1952)\end{array}$ \\
\hline Núm total de canais & $\mathrm{Nt}$ & $\begin{array}{l}\text { Resultado da contagem de rios de } \\
\text { cada bacia }\end{array}$ & $\begin{array}{c}\text { Strahler } \\
(1952)\end{array}$ \\
\hline
\end{tabular}

Quadro 2: Variáveis de hierarquização da bacia hidrográfica.

\begin{tabular}{|l|c|l|c|c|}
\hline $\begin{array}{l}\text { Variáveis da } \\
\text { hierarquização }\end{array}$ & Símbolo & \multicolumn{1}{|c|}{ Descrição } & Fórmula & Fonte \\
\hline Ordem de bacias & $\mathrm{U}$ & $\begin{array}{l}\text { Ordenação das ordens de bacia de } \\
\text { acordo com a ordenação dos canais. }\end{array}$ & ---------- & $\begin{array}{c}\text { Strahler } \\
(1952)\end{array}$ \\
\hline $\begin{array}{l}\text { Número de bacias de cada } \\
\text { ordem }\end{array}$ & $\mathrm{Nb}_{\mathrm{u}}$ & $\begin{array}{l}\text { Resultado da contagem de bacias } \\
\text { de determinada ordem. }\end{array}$ & $\begin{array}{c}\text { Strahler } \\
(1952)\end{array}$ \\
\hline Número total de bacias & $\mathrm{Ntb}$ & $\begin{array}{l}\text { Resultado da contagem de sub- } \\
\text { bacias de uma bacia. }\end{array}$ & $\begin{array}{c}\text { Strahler } \\
(1952)\end{array}$ \\
\hline
\end{tabular}

Os procedimentos adotados para o estabelecimento da hierarquia da rede fluvial das bacias hidrográficas foram baseados na proposta de Strahler (1952), que combinado ao de Horton (1945), permite a identificação do canal principal da bacia hidrográfica. 
De acordo com Strahler (1952), a identificação se inicia com os rios de $1^{\text {a }}$ ordem, que são aqueles que não recebem nenhum afluente, ou trechos de drenagem que não recebem outro trecho de drenagem. A partir da confluência de dois trechos de $1^{\mathrm{a}}$ ordem, forma-se um trecho de $2^{\mathrm{a}}$ ordem. A confluência de dois trechos de $2^{\mathrm{a}}$ ordem define um trecho de $3^{\mathrm{a}}$ ordem e assim sucessivamente. Quando dois trechos de ordens diferentes juntam-se, prevalece a maior ordem. O mesmo procedimento é adotado para hierarquização das bacias hidrográficas.

A utilização do MDE SRTM por meio do SIG possibilitou o levantamento e mensurações de variáveis morfométricas que constituíram os parâmetros básicos da comparação das bacias conforme as seguintes categorias de análise: linear, areal e hipsométrica. As variáveis selecionadas foram categorizadas de forma conceitual levando em consideração sua fonte, descrição e simbologia. A seguir são apresentadas as categorias descritas e as variáveis escolhidas. (Quadro 3,4,5) 
Quadro 3: Variáveis da análise linear da rede drenagem.

\begin{tabular}{|c|c|c|c|c|}
\hline Variáveis morfométricas & Símbolo & Descrição & Fórmula & Fonte \\
\hline $\begin{array}{l}\text { Comprimento do canal } \\
\text { principal }\end{array}$ & Lcp & Extensão total do maior rio da bacia. & ----------- & $\begin{array}{l}\text { Horton } \\
(1945)\end{array}$ \\
\hline $\begin{array}{l}\text { Comprimento total dos } \\
\text { canais }\end{array}$ & $\mathrm{Lt}$ & Soma dos comprimentos dos rios. & ----------- & $\begin{array}{l}\text { Horton } \\
(1945)\end{array}$ \\
\hline $\begin{array}{l}\text { Comprimento médio dos } \\
\text { canais de ordem }\end{array}$ & $\mathrm{Lm}_{\mathrm{u}}$ & $\begin{array}{l}\text { Somatório das extensões dos rios de } \\
\text { uma bacia dividido pelo número de } \\
\text { rios. }\end{array}$ & $\mathrm{Lm}_{\mathrm{u}}=\underline{\mathrm{L}}_{\mathrm{u}}$ & $\begin{array}{l}\text { Horton } \\
(1945)\end{array}$ \\
\hline Relação de bifurcação & $\mathrm{Rb}$ & $\begin{array}{l}\text { Relação entre o número de canais de } \\
\text { determinada ordem, pelo número de } \\
\text { canais de ordem superior. Bacia de } \\
\text { drenagem muito dissecada apresenta } \\
\text { valores entre } 3 \text { e } 4 \text {, enquanto bacias } \\
\text { colinosas, esses valores são próximos } \\
\text { de } 2 \text {. }\end{array}$ & $\mathrm{Rb}=\frac{\mathrm{N}_{\mathrm{u}}}{\mathrm{N}_{\mathrm{u}}+1}$ & $\begin{array}{l}\text { Horton } \\
(1932) \\
(1945)\end{array}$ \\
\hline $\begin{array}{l}\text { Relação entre comprimento } \\
\text { médio dos canais de cada } \\
\text { ordem }\end{array}$ & $\mathrm{R} \operatorname{lm}$ & $\begin{array}{l}\text { Corresponde à relação entre a média } \\
\text { dos comprimentos dos rios de } \\
\text { determinada ordem, pela média dos } \\
\text { comprimentos dos rios de ordem } \\
\text { imediatamente inferior. }\end{array}$ & $\mathrm{R} \operatorname{lm}=\frac{\mathrm{Lm}_{\mathrm{u}}}{\mathrm{Lm}_{\mathrm{u}}-1}$ & $\begin{array}{l}\text { Horton } \\
(1945)\end{array}$ \\
\hline $\begin{array}{l}\text { Relação do comprimento } \\
\text { médio dos canais e o índice } \\
\text { de bifurcação. }\end{array}$ & Rlb & $\begin{array}{l}\text { Representa a relação entre a rede de } \\
\text { drenagem e o desenvolvimento } \\
\text { fisiográfico das bacias hidrográficas. }\end{array}$ & $\mathrm{Rlb}=\frac{\mathrm{R} \operatorname{lm}}{\mathrm{Rb}}$ & $\begin{array}{l}\text { Horton } \\
(1945)\end{array}$ \\
\hline Gradiente do canal principal & Gcp & $\begin{array}{l}\text { Amplitude do canal principal dividida } \\
\text { por sua extensão. }\end{array}$ & $\mathrm{Gcp}=\frac{\mathrm{Hm}}{\mathrm{Lp}}$ & $\begin{array}{l}\text { Horton } \\
(1945) \\
\text { Strahler } \\
(1952)\end{array}$ \\
\hline $\begin{array}{l}\text { Extensão do percurso } \\
\text { superficial }\end{array}$ & Eps & $\begin{array}{l}\text { Distância média em que a água da } \\
\text { chuva teria de escoar sobre os terrenos } \\
\text { de uma bacia. }\end{array}$ & $\begin{array}{l}\text { Eps }=1 \\
(2 \times D d)\end{array}$ & $\begin{array}{l}\text { Horton } \\
(1945)\end{array}$ \\
\hline
\end{tabular}


Quadro 4: Variáveis da análise areal de bacias hidrográficas.

\begin{tabular}{|c|c|c|c|c|}
\hline Variáveis morfométricas & Símbolo & Descrição & Fórmula & Fonte \\
\hline Área da bacia & $\mathrm{A}$ & Extensão territorial da bacia. & ----------- & --------- \\
\hline Relação de áreas médias & $\mathrm{Ra}$ & $\begin{array}{l}\text { Relação de áreas das bacias dos canais } \\
\text { de dada ordem pela média das bacias } \\
\text { contribuintes dos canais de ordem } \\
\text { inferior. }\end{array}$ & $\mathrm{Ra}=\frac{\mathrm{Am}_{\mathrm{u}}}{\mathrm{Am}_{\mathrm{u}}-1}$ & $\begin{array}{c}\text { Schumm } \\
(1956),\end{array}$ \\
\hline Perímetro & $\mathrm{P}$ & Perímetro da bacia. & ----------- & ---------- \\
\hline Comprimento da bacia & $\mathrm{Lb}$ & $\begin{array}{l}\text { Maior extensão, em linha reta, da bacia } \\
\text { entre a foz e a cabeceira mais distante } \\
\text { da bacia. }\end{array}$ & ---------- & $\begin{array}{c}\text { Schumm } \\
(1956)\end{array}$ \\
\hline Densidade de drenagem & Dd & $\begin{array}{l}\text { Relação entre o comprimento da rede } \\
\text { de drenagem e a área da bacia. }\end{array}$ & $\mathrm{Dd}=\underline{\mathrm{L}}$ & $\begin{array}{c}\text { Horton } \\
(1945)\end{array}$ \\
\hline Fator de forma & $\mathrm{Kf}$ & $\begin{array}{l}\text { E a relação morfométrica entre a forma } \\
\text { da bacia com a de um retângulo. }\end{array}$ & $\mathrm{Kf}=\underline{\mathrm{A}}$ & $\begin{array}{l}\text { Horton } \\
(1932)\end{array}$ \\
\hline Coeficiente manutenção & $\mathrm{Cm}$ & $\begin{array}{l}\text { Estimativa da área mínima que o canal } \\
\text { de drenagem necessita para se } \\
\text { implementar e desenvolver. }\end{array}$ & $\mathrm{Cm}=\frac{1}{\mathrm{Dd}} \times 1000$ & $\begin{array}{c}\text { Schumm } \\
(1953)\end{array}$ \\
\hline
\end{tabular}

Quadro 5: Variáveis da análise hipsométrica de bacias hidrográficas.

\begin{tabular}{|c|c|c|c|c|}
\hline Variáveis Morfométricas & Símbolo & Descrição & Fórmula & Fonte \\
\hline Altitude mínima & Alt.min & $\begin{array}{l}\text { Menor altitude altimétrica localizada na } \\
\text { foz do canal principal. }\end{array}$ & ----------- & ---------- \\
\hline Altitude média ou elevação & E & $\begin{array}{l}\text { Refere-se à altitude média da bacia, } \\
\text { calculado pela curva hipsográfica, onde } \\
\mathrm{a}=\text { área entre curvas e = altitude média } \\
\text { entre duas curvas de nível } \\
\text { consecutivas; } \mathrm{A}=\text { área da bacia. }\end{array}$ & $\mathrm{E}=\frac{\sum \mathrm{ae}}{\mathrm{A}}$ & $\begin{array}{l}\text { Wisler; } \\
\text { Brater, } \\
(1964)\end{array}$ \\
\hline Altitude mediana & Alt.med & $\begin{array}{l}\text { Corresponde à altitude na qual metade } \\
\text { da área da bacia fica acima dela e } \\
\text { metade abaixo }\end{array}$ & ------------ & \\
\hline Amplitude topográfica & $\mathrm{Hm}$ & $\begin{array}{l}\text { Diferença de altitudes entre o ponto } \\
\text { mais baixo da bacia (foz) e o ponto de } \\
\text { maior altitude. }\end{array}$ & $\begin{array}{l}\Delta \mathrm{H}=\text { Alt.max- } \\
\text { Alt.min }\end{array}$ & $\begin{array}{l}\text { Strahler } \\
(1952)\end{array}$ \\
\hline Relação de relevo & $\mathrm{Rr}$ & $\begin{array}{l}\text { Relação entre a amplitude altimétrica e } \\
\text { o maior comprimento da bacia. Quanto } \\
\text { maior o valor, maior será o desnível } \\
\text { entre a cabeceira e a foz e maior a } \\
\text { declividade média da bacia. }\end{array}$ & $\mathrm{Rr}=\frac{\mathrm{Hm}}{\mathrm{L}}$ & $\begin{array}{c}\text { Schumm } \\
(1956)\end{array}$ \\
\hline Índice de rugosidade & Ir & $\begin{array}{l}\text { Produto entre a amplitude altimétrica e } \\
\text { a densidade de drenagem. }\end{array}$ & $\mathrm{HD}=\mathrm{HxDd}$ & $\begin{array}{l}\text { Melton } \\
(1957)\end{array}$ \\
\hline
\end{tabular}

No que diz respeito a geração das curvas hipsográficas e de volume, para cada bacia hidrográfica analisada, estas foram gerada por meio da projeção em um gráfico de eixo de coordenadas cartesianas as variações das áreas e volume das faixas altimétricas, de forma 
que a curva é relacionada com a forma de um quadrado com os valores máximos das abscissas e ordenadas igual a 1.0, ou $100 \%$. Com a geração das curvas partiu-se para o levantamento da integral hipsométrica (IH) e a integral volumétrica (IV), a fim de avaliar a relação de material erodido (IH-IV) conforme a proposta de (Strahler, 1952).

Para geração dos perfis longitudinais foi utilizado o MDE SRTM e o software ArcGis 9.2. Os comandos específicos para geração do perfil foram executados por meio da extensão $3 D$ Analyst, a qual possibilitou a projeção das cotas altimétricas do canal em um gráfico de eixo de coordenadas (XY). Em seguida os dados foram exportados para formato *.xls, compatível com o software Excel, no intuito de segmentar o comprimento total dos perfis longitudinais, de acordo com a alteração da ordem hierárquica do canal principal de cada bacia hidrográfica para que as descontinuidades fossem realçadas.

\section{- Quarta Etapa - Análises hidrossedimentológicas}

Para sistematização dos dados hidrológicos provenientes das estações de monitoramento das bacias hidrográficas em análise, foi necessário à utilização do software Excel. Os dados hidrossedimentológicos das bacias hidrográficas, em termos da variabilidade temporal sazonal dos débitos, bem como os tipos de regimes de fluxos foram sistematizados de forma a permitir o calculo da descarga sólida de sedimentos em suspensão (Qss) e produção específica de sedimentos em suspensão (Pss).

Para realização do cálculo da Qss foram utilizadas as variáveis; tempo (segundos), vazão (m3/s) e concentração de sedimentos em susepnsão $(\mathrm{mg} / \mathrm{l})$. O produto destas três variáveis resultou na Qss (t/dia), conforme a seguinte equação:

$$
\text { Qss }=0.0864 \times \text { Q x Css }
$$

Qss = descarga sólida dos sedimentos em suspensão (t/dia); 
Css = concentração de sedimentos em suspensão (mg/l);

$\mathrm{Q}=$ descarga líquida $\left(\mathrm{m}^{3} / \mathrm{s}\right)$

$0.0864=$ Constante numérica referente à conversão de unidade de tempo e unidade métrica.

Uma vez determinados os valores de Qss das amostras do período (2002-2006), foram traçadas as curvas-chave de sedimentos em suspensão das estações de acordo com a equação potencial a seguir:

$$
\mathrm{Qss}=\mathrm{a} \cdot \mathrm{Q}^{\mathrm{b}}
$$

Qss = descarga sólida dos sedimentos em suspensão (t/dia);

$\mathrm{Q}=$ descarga líquida $\mathrm{em} \mathrm{m} / \mathrm{s}^{3}$

$\mathrm{a}$ e $\mathrm{b}=$ constantes de ajuste.

Foi necessário calcular diferentes curvas para representar adequadamente a correlação entre os dados de Q e Qss, sendo que o limite aceitável do coeficiente de determinação $\left(\mathrm{r}^{2}\right)$ foi igual a 0,6 , de acordo com o procedimento adotado por Lima et al., (2004). O coeficiente de determinação é um indicador que varia de 0 a 1 e revela a proximidade dos valores estimados da linha de tendência em correspondência com os dados verdadeiros. Uma linha de tendência é mais confiável quando o valor de $\left(\mathrm{r}^{2}\right)$ é igual ou próximo a 1. Em seguida as curvas chaves obtidas foram aplicadas a toda a série de dados de vazão média diária, e a partir dessa série foram obtidos os valores de médias diárias, mensais e anuais da descarga sólida em suspensão para cada uma das estações.

Com isto foi possível calcular a produção especifica de sedimentos em suspensão (Pss), que representa a relação entre o processo de perdas de materiais e a área da bacia hidrográfica. 


$$
\text { Pss }=\underline{\text { QsS }}
$$

Onde:

Pss $=$ produção específica da produção de sedimentos em suspensão $\left(\mathrm{t} / \mathrm{km}^{2} / \mathrm{dia}\right)$;

Qss = descarga sólida dos sedimentos em suspensão (t/dia);

$\mathrm{A}=$ área da bacia $\left(\mathrm{km}^{2}\right)$.

Para análise do período considerado neste estudo (2002-2004) foram criados gráficos do tipo box-plot, os quais mostram os valores: máximo (max); mínimo (min); mediana (méd), quartil 1 (Q1) e quartil 3 (Q3). O quartil 1 é o valor que deixa 25\% dos valores de Pss abaixo e 75\% acima do respectivo valor. O quartil 3 é o valor que deixa 75\% dos dados abaixo e $25 \%$ acima dele. A mediana é o valor posiciona $50 \%$ dos dados acima e abaixo do valor de Pss.

Do conjunto total de dados analisados de Pss foram excluídos os valores com comportamento muito diferente dos demais, denominados de outliers, para isto foi adotado como limite de exclusão, o limiar de 1.5 x IQR (IQR= intervalo interquantis, Q3-Q1).

Por fim, foi criado um gráfico semilog, onde no eixo $(\mathrm{X})$ foram projetados os valores médios do nível fluviométrico $(\mathrm{m})$, concentração de sedimentos em suspensão (mg/l) e vazão, e no eixo (Y), os valores da produção especifica de sedimentos em suspensão $\left(\mathrm{t} / \mathrm{km}^{2} / \mathrm{dia}\right)$ correspondente ao período dos dados do eixo $(\mathrm{X})$. O gráfico mostra os valores das correlações entre as variáveis e o deslocamento das linhas de tendência, as quais permitem avaliar a influência das variáveis hidrodinâmicas sob a Pss das bacias hidrográficas. 


\section{RESULTADOS}

\subsection{Implantação do banco de dados geográficos e processamento de modelos digitais}

de elevação

Foi implantado um banco de dados geográficos, no qual foram sistematizados os dados espaciais e tabulares utilizados nas análises desenvolvidas na pesquisa. Os dados provenientes do processamento digital do MDE SRTM foram armazenados no banco em planos de informação de categorias específicas tais como: rede de drenagem, limite das bacias hidrográficas, canal principal, hierarquia de canais, declividade, imagem relevo realçado, hipsometria. Os dados tabulares foram inseridos de forma a manter o relacionamento espacial das feições e atributos. A seguir são apresentados os componentes do banco de dados geográficos implantado (Figura 26).

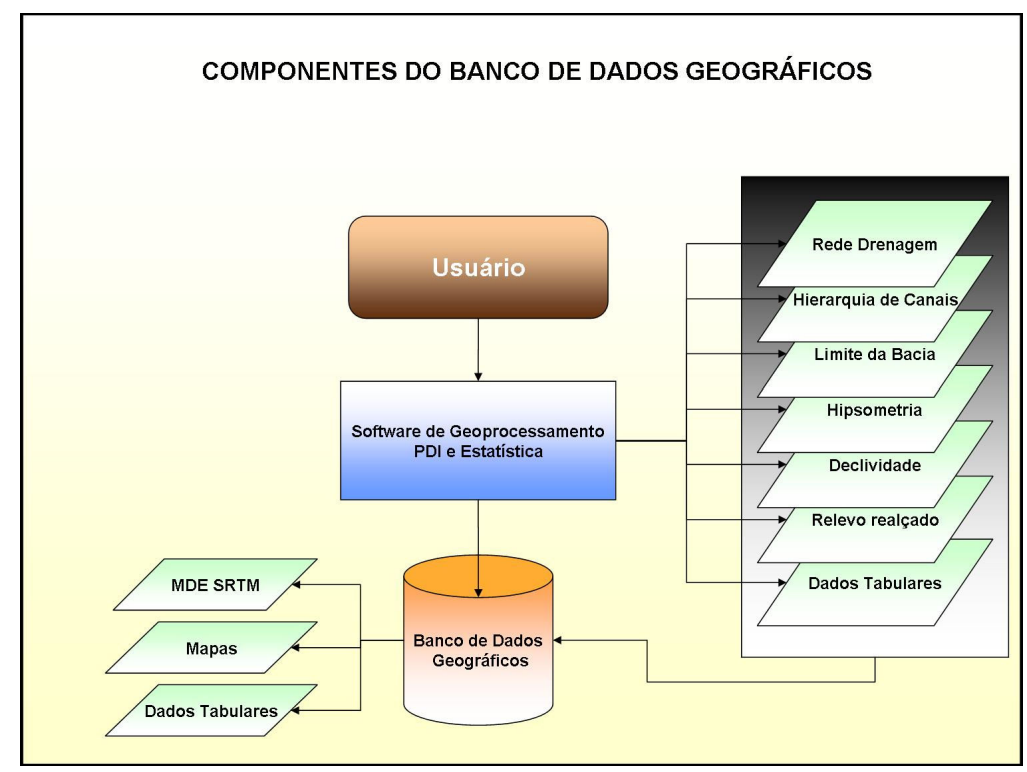

Figura 26: Componentes do banco de dados geográficos provenientes do desenvolvimento da pesquisa. Org: Aguiar (2009). 
A arquitetura do sistema adotada possibilitou ao usuário a realização de consultas para edição, extração e visualização das informações de interesse da pesquisa, além de permitir a organização das atividades de levantamento das variáveis morfométricas. Embora não tenhamos trabalhado com o cruzamento dos planos de informações, o banco de dados possibilita que isto seja realizado futuramente, além do armazenamento de novos dados, principalmente imagens de satélites referente as áreas de confluências dos rios Iguatemi e Piquiri com o rio Paraná.

O processamento digital do MDE SRTM possibilitou a geração de mapas de informação do relevo de cada bacia hidrográfica, especificadamente mapas hipsométricos, de declividades e relevo realçado. A seguir são apresentados os resultados da geração destes produtos cartográficos.

\section{a) Hipsometria}

O mapa hipsométrico da bacia hidrográfica do rio Iguatemi (Figura 27), permite-nos observar que no intervalo entre 229-250m há a ocorrência da confluência do rio Iguatemi com o rio Jagui. Esta bacia hidrográfica apresentou 8 classes hipsométricas com equidistância de 50m. O rio Jagui é o segundo maior rio desta bacia, e após sua área de confluência a uma área de planície fluvial, onde há o acumulo de materiais transportados pelo escoamento superficial ao longo das vertentes e fundos de vales das bacias hidrográficas. 


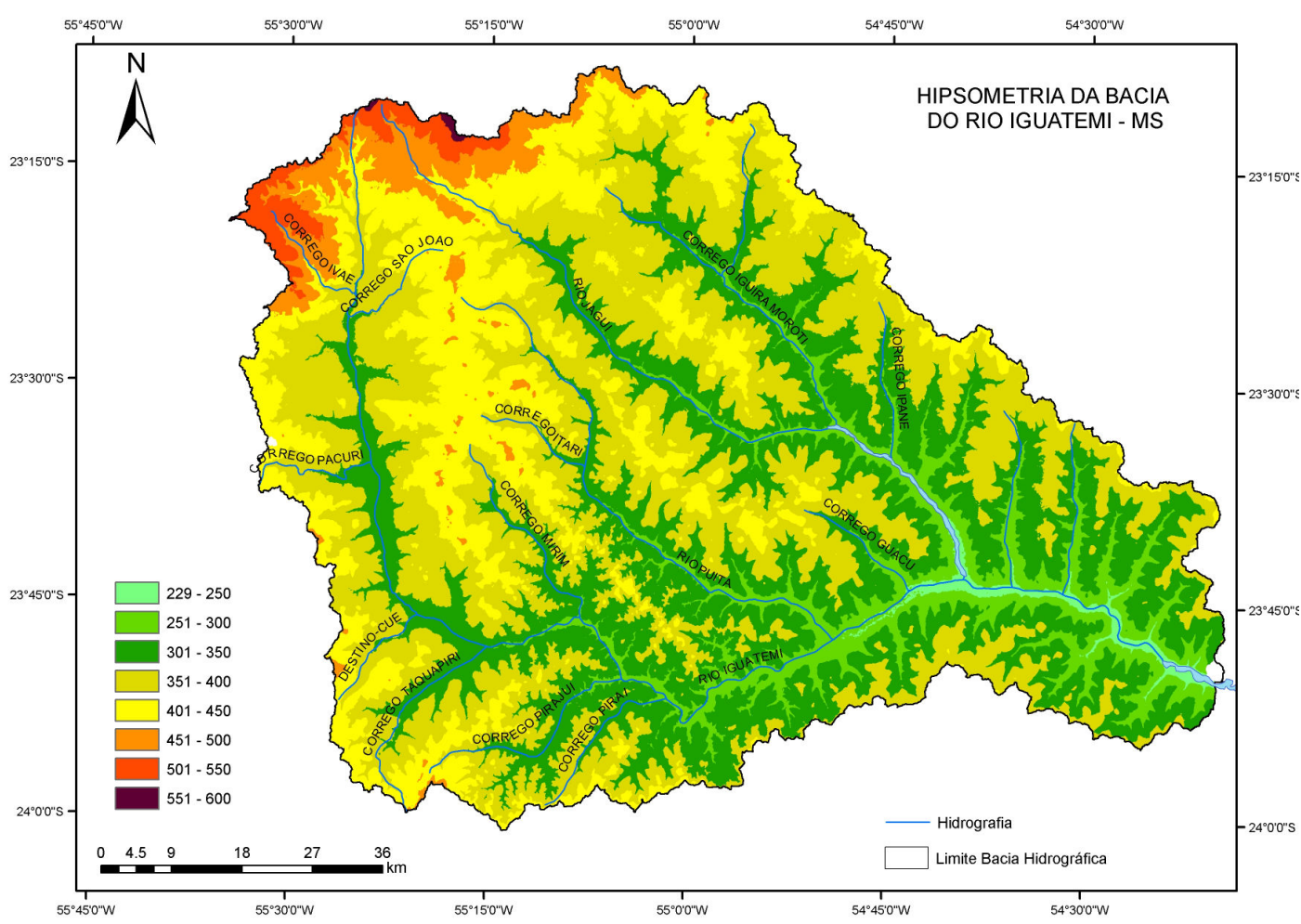

Figura 27: Mapa hipsométrico da bacia hidrográfica do rio Iguatemi - MS. Org: Aguiar (2009).

Em relação à hipsometria da bacia hidrográfica do rio Piquiri (Figura 28), observase que esta possui um número maior de classes em relação à bacia hidrográfica do rio Iguatemi, contabilizando no total 21 classes hipsométricas. Notamos que a distribuição das classes tende a apresentar uma diminuição das áreas das faixas altimétricas em direção das cabeceiras de drenagem. Ambas as bacias hidrográficas possuem a mesma cota altimétrica mínima, 229m. 


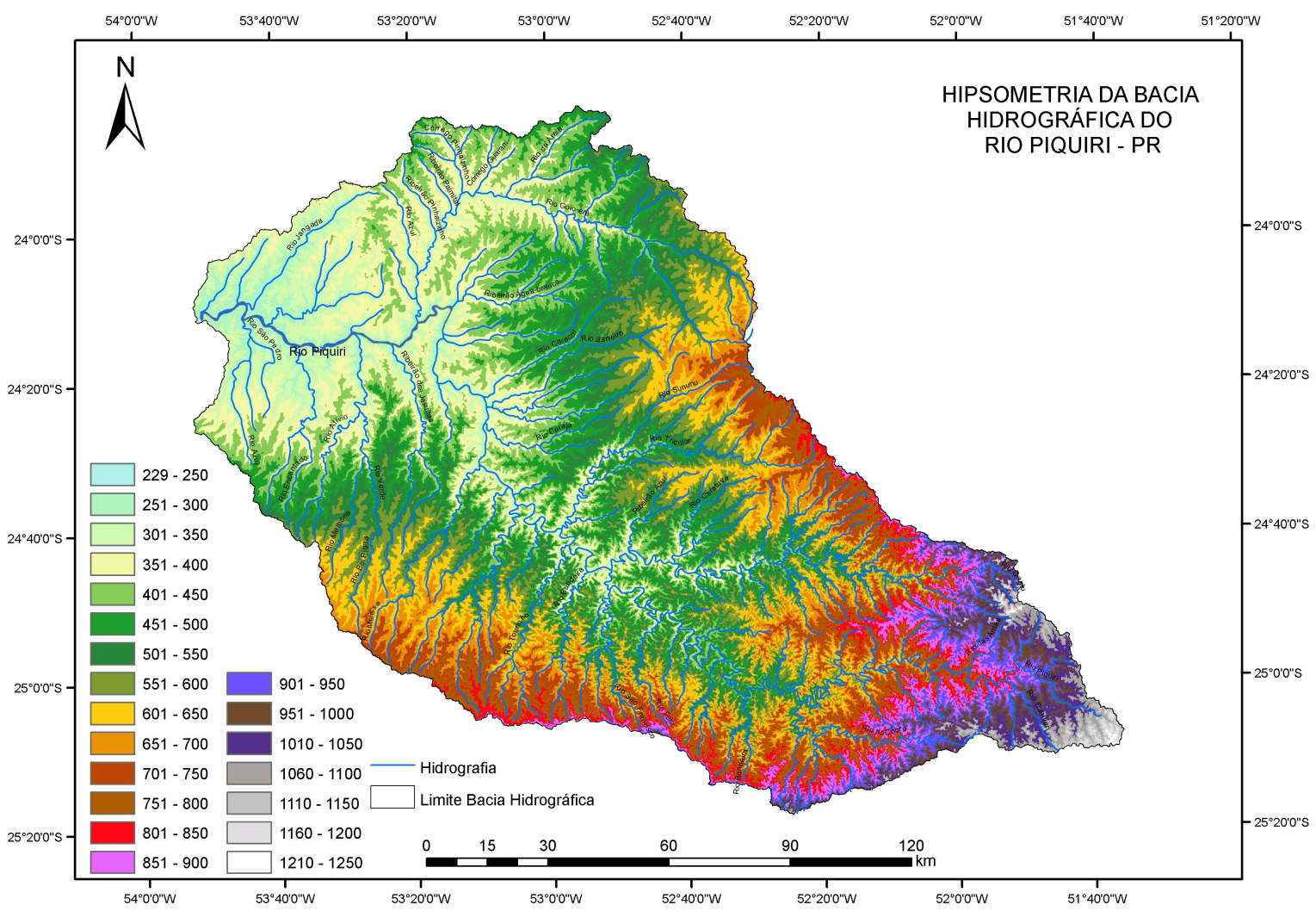

Figura 28: Mapa hipsométrico da bacia hidrográfica do rio Piquiri - PR. Org: Aguiar (2009).

\section{b) Declividade}

Os mapas de declividade das bacias hidrográficas dos rios Iguatemi e Piquiri, foram produzidos com intervalos de classe de acordo com a proposta adaptada da Embrapa (2004), (Figura 29, 30). Com o calculo das áreas de cada classe do mapa de declividade foi possível identificar as características do relevo nas bacias hidrográficas. 


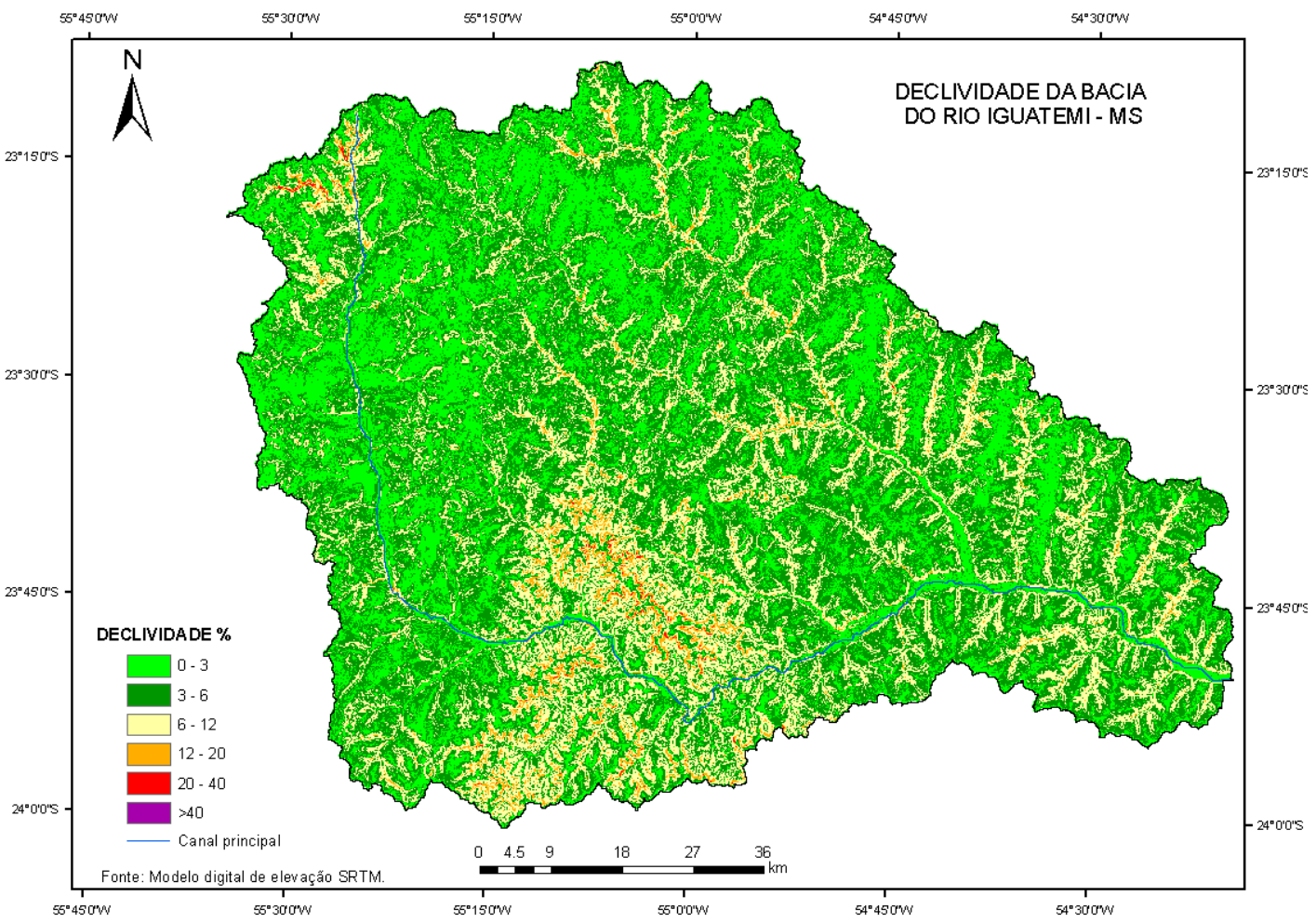

Figura 29: Mapa de declividades da bacia hidrográfica do rio Iguatemi - MS. Org: Aguiar (2009).

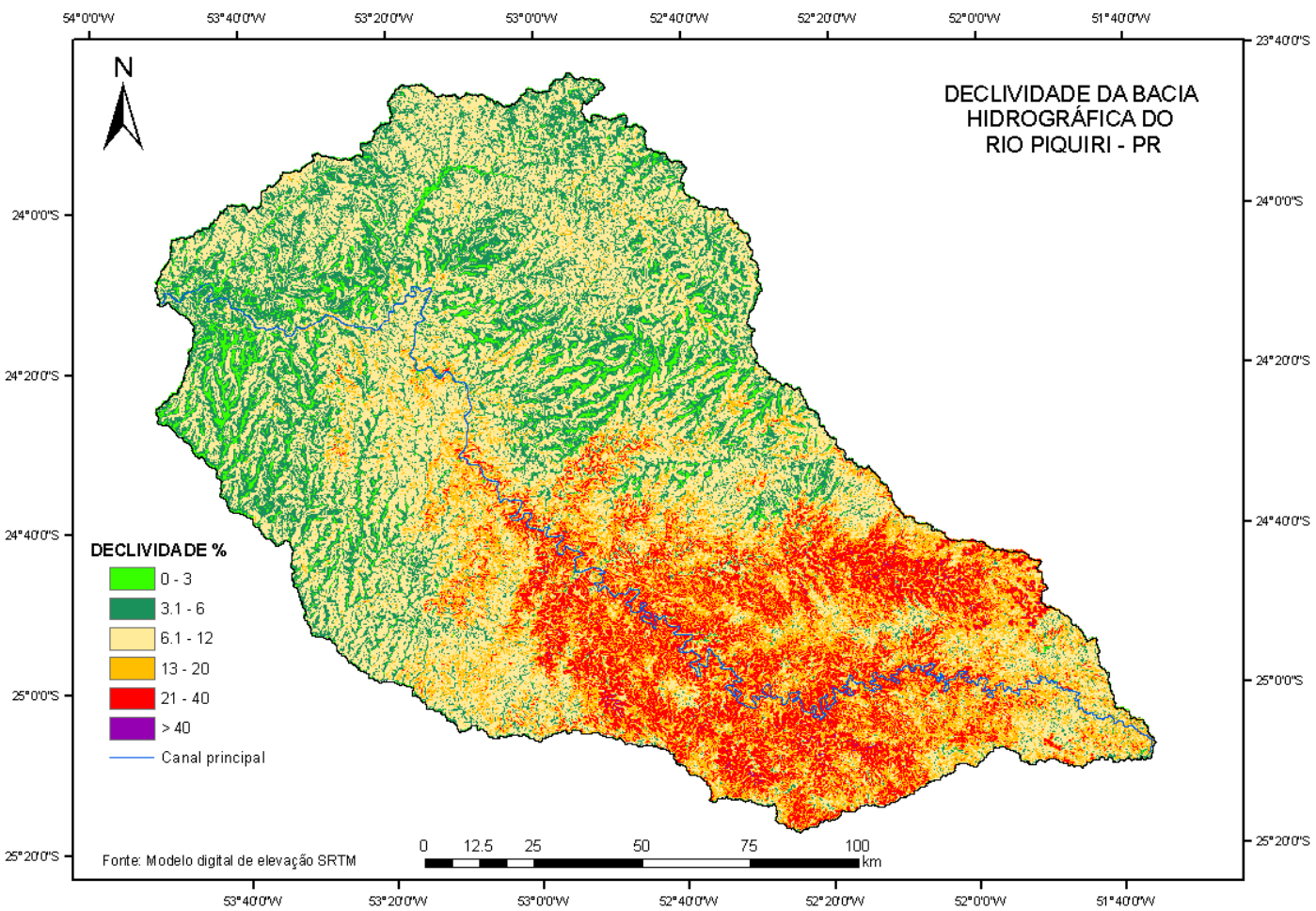

Figura 30: Mapa de declividades da bacia hidrográfica do rio - PR. Org: Aguiar (2009). 
$\mathrm{Na}$ da Tabela 2 podemos observar que há na bacia hidrográfica do rio Iguatemi a predominância da classe de declividade de $3-6 \%$, a qual está relacionada com o relevo do tipo plano a suave ondulado. Em relação à área total desta bacia hidrográfica 74\% das áreas estão abaixo de $6 \%$. A classe de $6-12 \%$ representam $22,3 \%$ da área total. Apenas 3,2\% da área da bacia hidrográfica apresentaram declividade entre $12 \%$ a $20 \%$,com relevo ondulado a forte ondulado.

Tabela 2: Porcentagens das classes de declividade e tipos de relevo da bacia hidrográfica do rio Iguatemi - MS.

\begin{tabular}{cccc}
\hline Classe $\%$ & Relevo & Área $\left(\mathrm{km}^{2}\right)$ & Área $\%$ \\
\hline $0-3$ & Plano & $2.547,118$ & $32 \%$ \\
$3-6$ & Plano a suave ondulado & $3.366,156$ & $42,3 \%$ \\
$6-12$ & Suave ondulado a ondulado & $1.768,844$ & $22,2 \%$ \\
$12-20$ & Ondulado a forte ondulado & 254,665 & $3,2 \%$ \\
$20-40$ & Forte ondulado a montanhoso & 22,441 & $0,3 \%$ \\
$>40$ & Montanhoso & 0,057 & $0,0 \%$ \\
\hline Total & & $7.959,281$ & $100 \%$ \\
\hline
\end{tabular}

Com base na classificação das declividades em alta, média e baixa declividade, notamos que a declividade predominante da bacia hidrográfica do rio Iguatemi é baixa e o tipo de relevo predominante é plano a suave ondulado. Na bacia hidrográfica do rio Piquiri pode-se observar na Tabela 3, que a classe de declividade predominante é a de 6 a $12 \%$, apresentando relevo suave ondulado a ondulado. A classe de declividade de 12 - 20\% ocupam $16 \%$ da área total, diferentemente da bacia hidrográfica do rio Iguatemi que apresenta apenas 3.2\%. A declividade predominante nesta bacia hidrográfica é de média a alta, com a ocorrência de relevo ondulado a forte ondulado e pequenas áreas de relevo montanhoso. 
Tabela 3 Porcentagens das classes de declividade e tipos de relevo da bacia hidrográfica do rio Piquiri - PR.

\begin{tabular}{cccc}
\hline Classe $\%$ & Relevo & Área $\left(\mathrm{km}^{2}\right)$ & Área $\%$ \\
\hline $0-3$ & Plano & $1.882,122$ & $8,7 \%$ \\
$3-6$ & Plano a suave ondulado & $4.925,426$ & $22,8 \%$ \\
$6-12$ & Suave ondulado a ondulado & $8.341,375$ & $38,6 \%$ \\
$12-20$ & Ondulado a forte ondulado & $3.447,318$ & $16,0 \%$ \\
$20-40$ & Forte ondulado a montanhoso & $2.823,610$ & $13,1 \%$ \\
$>40$ & Montanhoso & 179,755 & $0,8 \%$ \\
\hline Total & & $21.599,605$ & $100 \%$ \\
\hline
\end{tabular}

Segundo Rostagno (1999) apud Pinto et all., 2005), na classe de 12-20\% de declividade, práticas de conservação mais complexas são necessárias para utilização dessas áreas e, nas classes com declividade acima de 20\%, o relevo acentuado faz com que o escoamento superficial seja rápido na maior parte dos solos, podendo causar sérios problemas de erosão.

\section{c) Relevo realçado}

Este produto cartográfico produzido por meio do processamento do MDE SRTM possibilitou a representação das bacias hidrográficas com aparência tridimensional (Figuras 31, 32). É possível visualizar que na bacia hidrográfica do rio Iguatemi há a ocorrência de pequenas superfícies erosivas tabulares, provenientes de relevo residual de topos aplainado, provavelmente testemunhos de superfície aplainada, e áreas de forte dissecação fortemente correlacionadas com as áreas de maior declividade da bacia hidrográfica, conforme abordagem feita anteriormente a respeito das declividades.

No trecho inferior do rio Iguatemi observa-se a ocorrência de planícies, que de acordo com Radam (1982) apresentam relevo plano resultante da acumulação fluvial em área periodicamente alagada. 


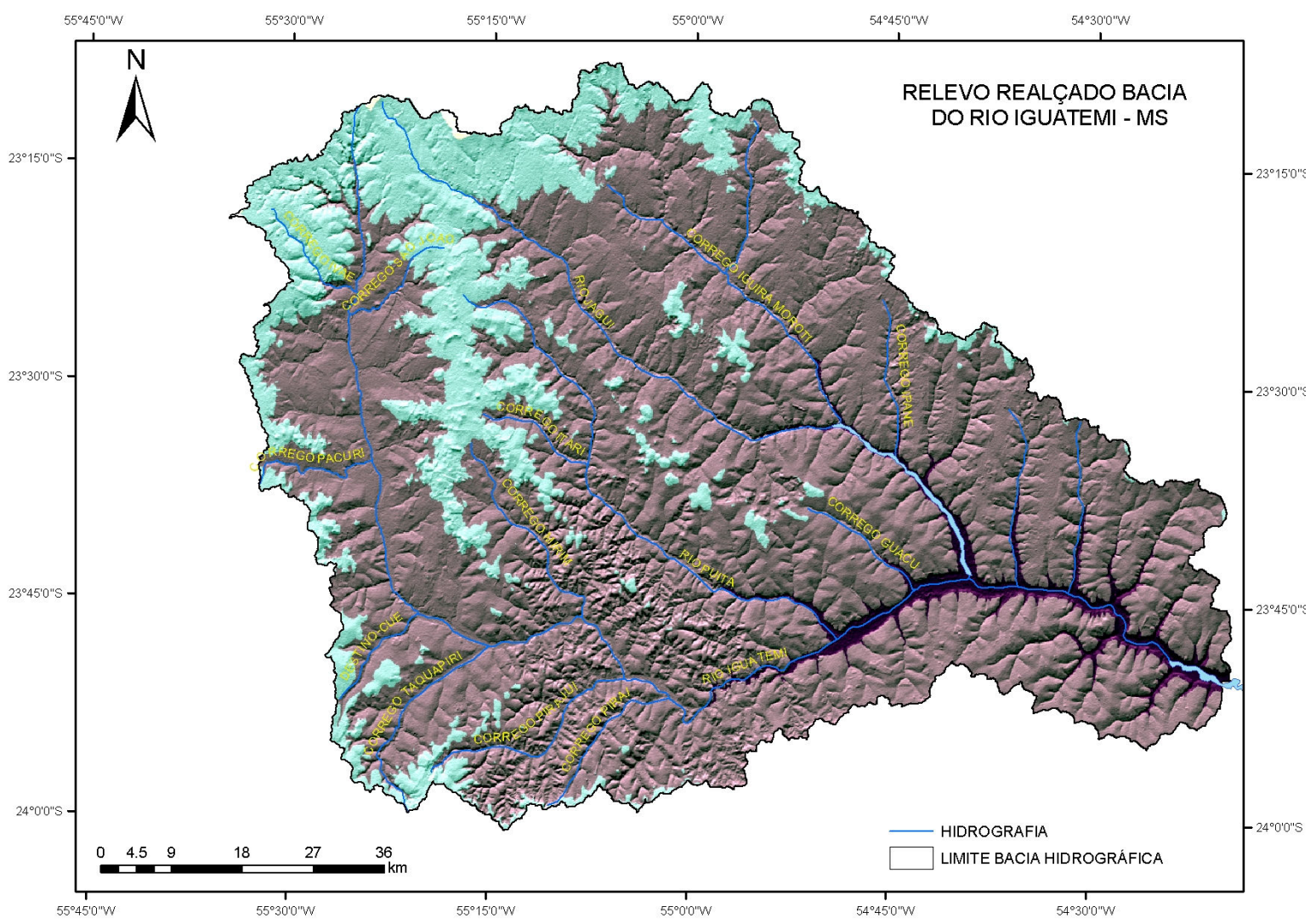

Figura 31: Representação tridimensional da bacia hidrográfica do rio Iguatemi - MS.Org: Aguiar (2009).

Em relação a bacia hidrográfica do rio Piquiri (Figura 32), observamos que as vertentes são mais dissecadas, quando comparadas com as da bacia hidrográfica do rio Iguatemi. 


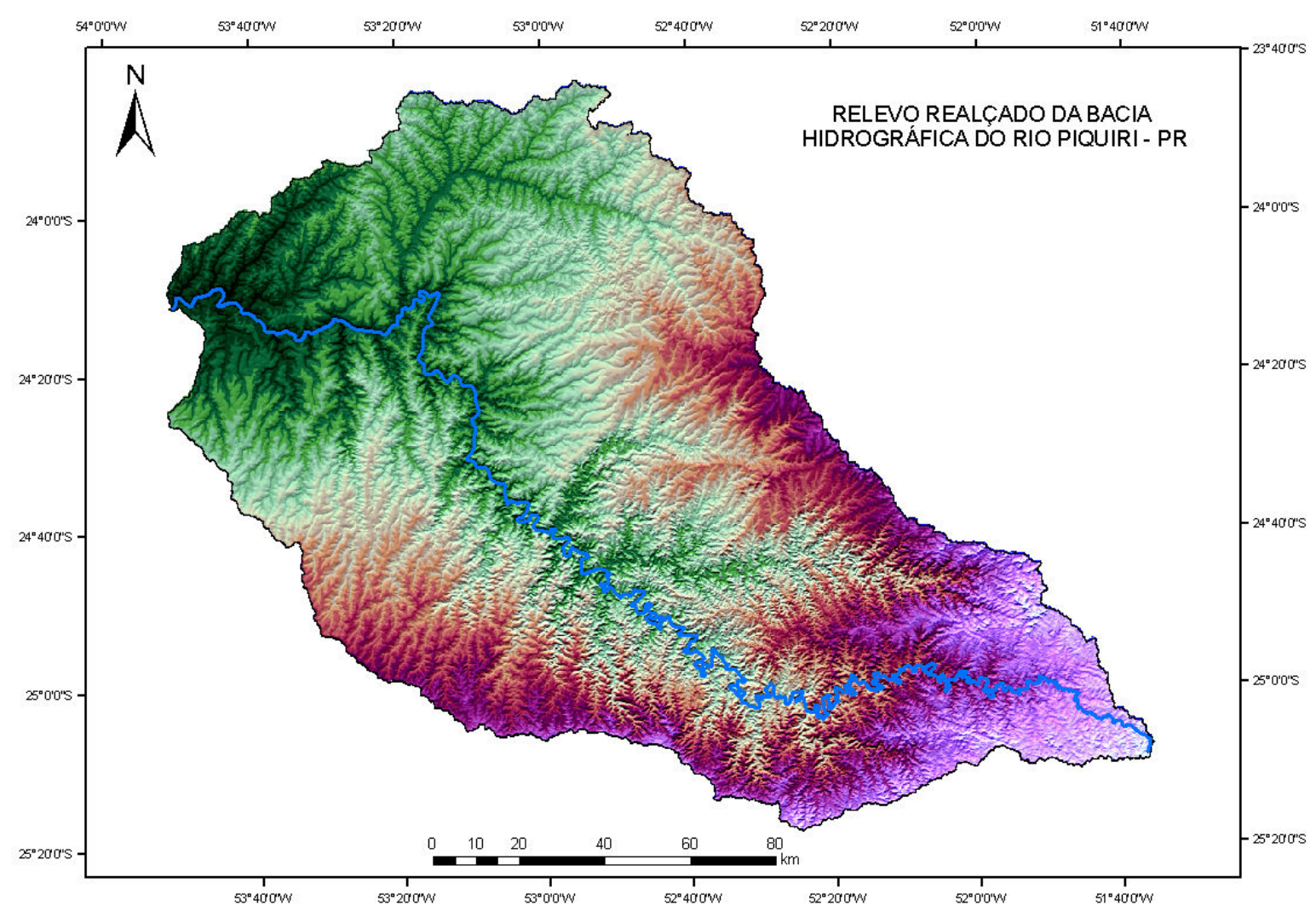

Figura 32: Representação tridimensional da bacia hidrográfica do rio Piquiri - PR.Org: Aguiar (2009). 


\subsection{Análises comparativas das variáveis hidrogeomorfológicas}

Esta etapa envolveu a análise dos dados obtidos por meio da extração da rede de drenagem, limites das bacias hidrográficas, mensurações morfométricas, perfis longitudinais dos canais principais e curvas hipsográficas e de volume das bacias hidrográficas dos rios Iguatemi e Piquiri.

\section{a) Extração da rede de drenagem, delimitação das bacias hidrográficas e hierarquia fluvial.}

Na Figura 33, temos o resultado da extração automática da rede de drenagem, limite da bacia hidrográfica do rio Iguatemi e a hierarquização dos trechos de drenagem da bacia hidrográfica do rio Iguatemi, baseada na inferência de fluxo.

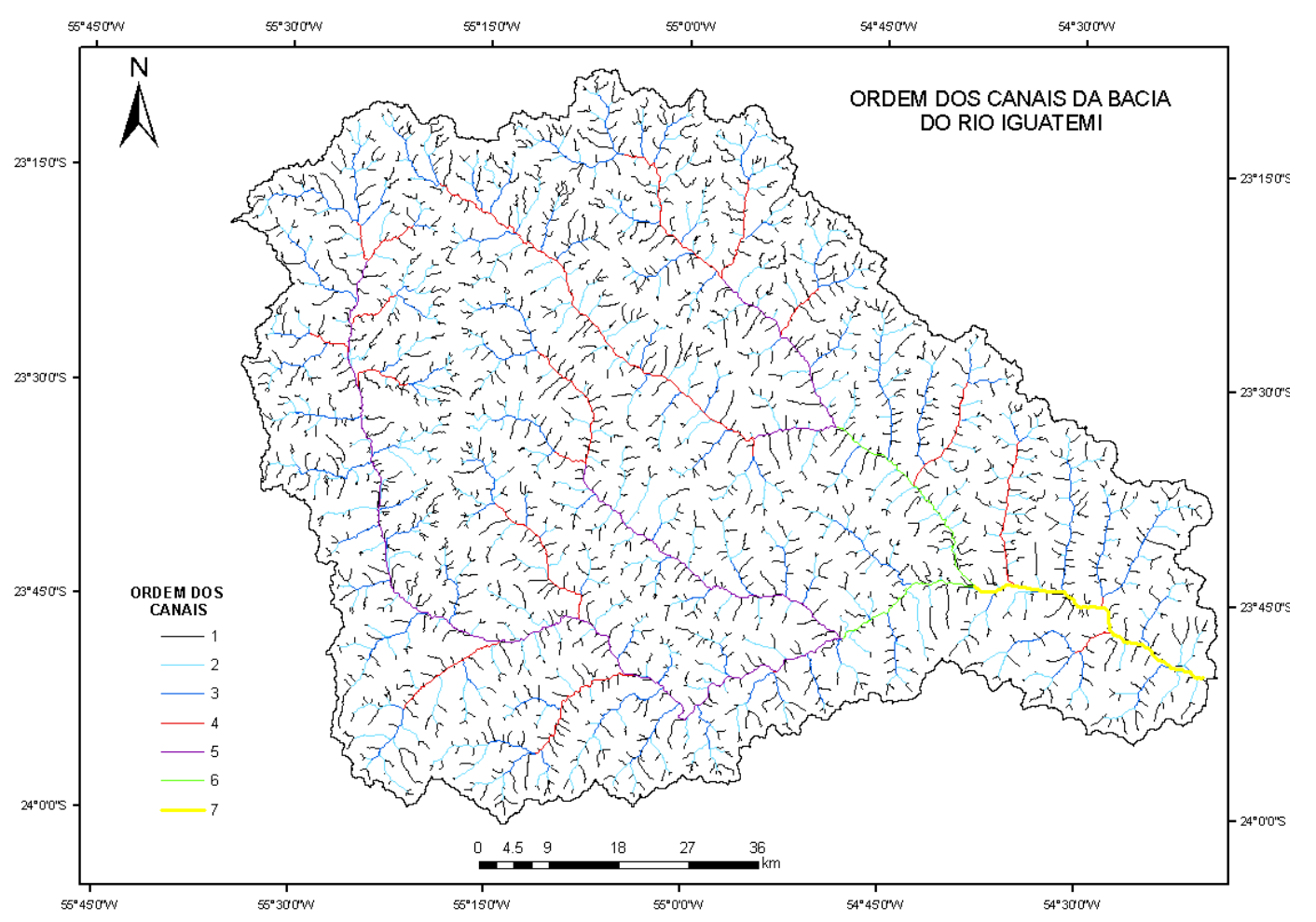

Figura 33: Rede de drenagem com hierarquia dos canais e limite da bacia hidrográfica do rio Iguatemi - MS. Org: Aguiar (2009).

De acordo com a hierarquização realizada esta bacia hidrográfica é classificada como de $7^{\mathrm{a}}$ ordem, assim como foi determinado para a bacia hidrográfica do rio Piquiri, 
portanto as análises estão referenciadas para bacias hidrográficas de mesma magnitude. $\mathrm{Na}$ Figura 34, temos a rede de drenagem, o limite e a hierarquização dos canais da bacia hidrográfica do rio Piquiri.

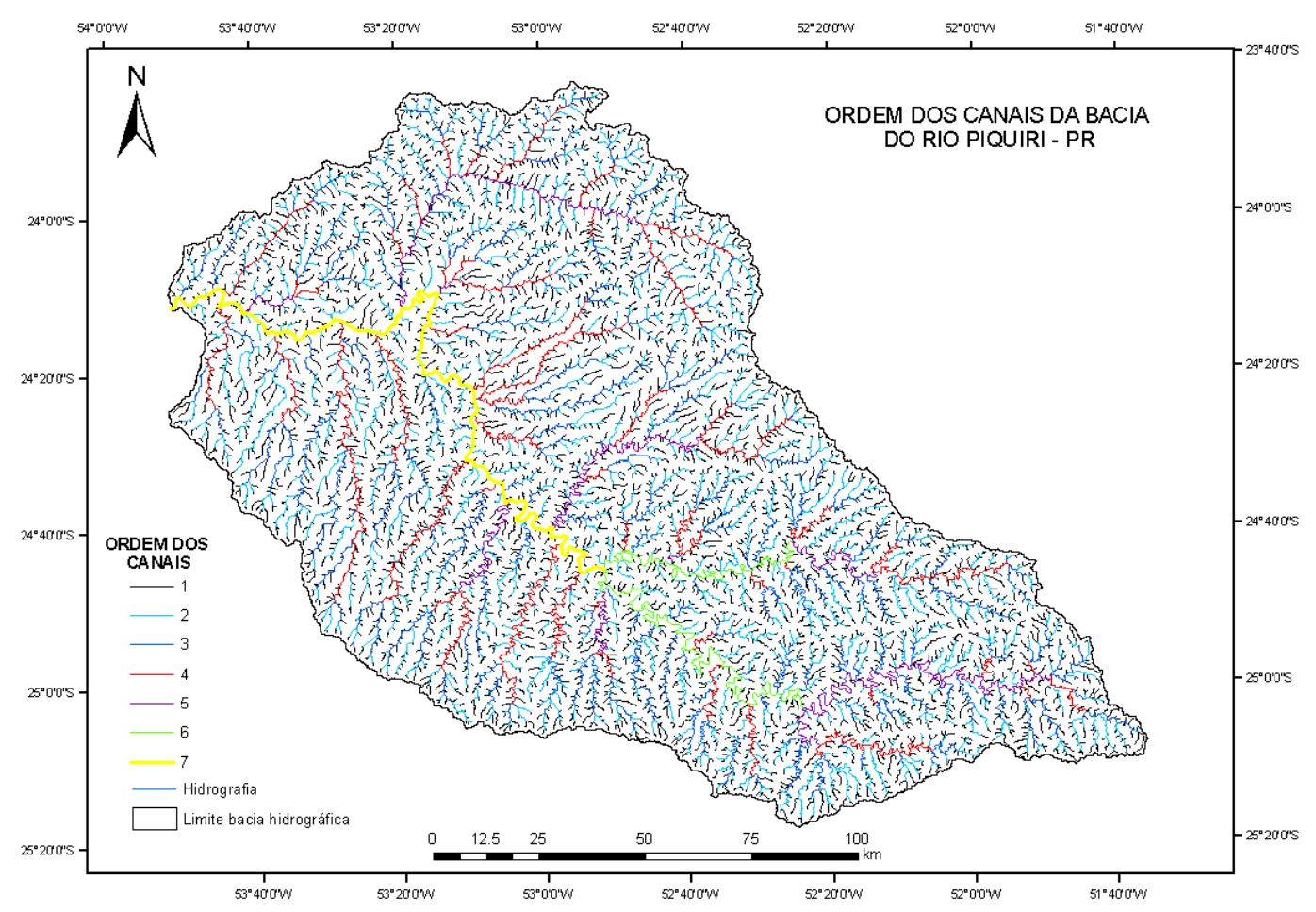

Figura 34: Rede de drenagem com hierarquia dos canais e limite da bacia hidrográfica do rio Piquiri - PR. Org: Aguiar (2009).

Para cada ordem de canal da rede de drenagem das bacias hidrográficas analisadas foram geradas suas áreas de drenagem diretas. Nas Figuras 35 e 36, estão representadas as distribuições das áreas classificadas para cada ordem das bacias hidrográficas. Notamos que na bacia hidrográfica do rio Iguatemi as áreas de drenagem direta de $5^{\text {a }}$ ordem são mais representativas no canal principal, enquanto na bacia hidrográfica do rio Piquiri a área de drenagem direta mais representativa no canal principal é a de $7^{\mathrm{a}}$ ordem. Na bacia hidrográfica do rio Piquiri observa-se que esta segue uma tendência normal segundo a lei das áreas médias de Schumm (1956), enquanto para bacia do rio Iguatemi verifica-se uma anormalidade, uma vez que a seqüência geométrica das áreas não se apresenta crescente. 


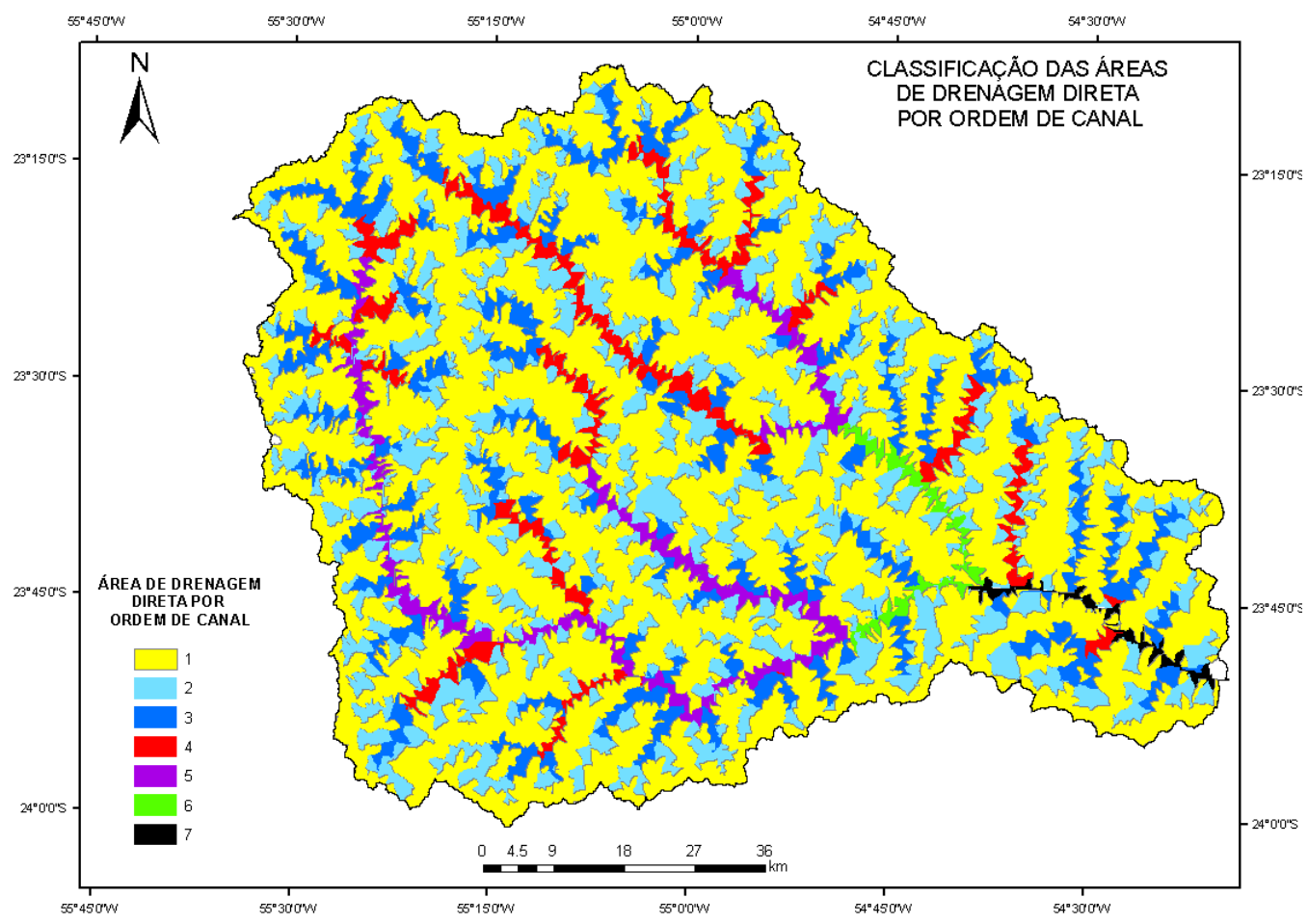

Figura 35: Classificação das áreas de drenagem direta por ordem de canais da bacia do rio Iguatemi - MS. Org: Aguiar (2009).

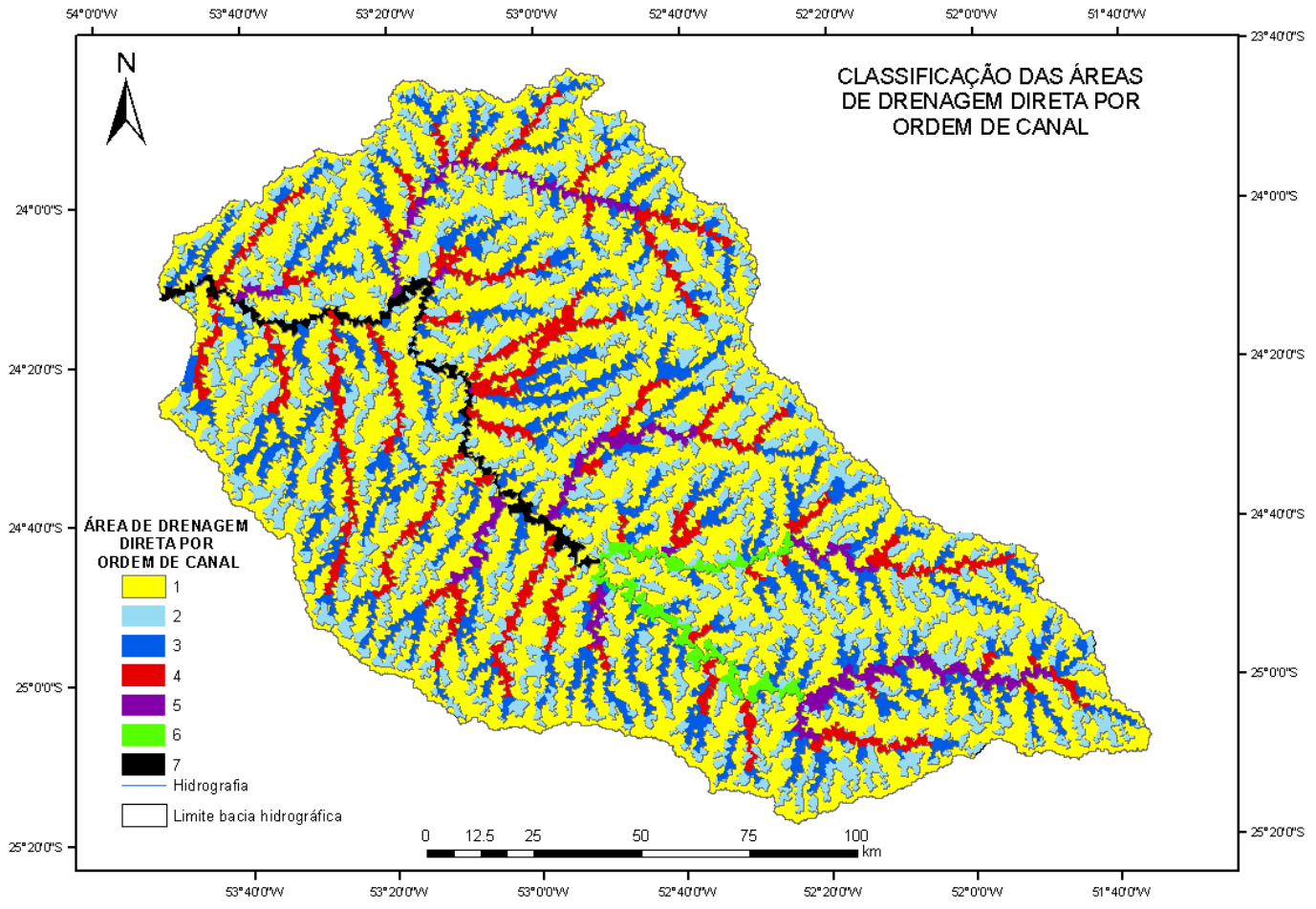

Figura 36: Classificação das áreas de drenagem direta por ordem de canais da bacia do rio Piquiri PR. Org: Aguiar (2009). 


\section{b) Análises comparativas morfométricas lineares, areais e hipsométricas.}

Os resultados das análises de mensurações morfométricas foram fundamentais para permitir a explicação das diferenças das formas e interpretar processos observados nas bacias hidrográficas. Para mostrar a relação da hierarquia, quantidade, extensão e área, foram gerados para cada bacia hidrográfica gráficos logaritmos que permitem visualizar as variáveis por meio de uma linha de tendência.

A intenção de se criar o gráfico logarítmico, além da visualização do posicionamento das variáveis, foi a de comparar as redes drenagem das bacias hidrográficas em questão, de acordo com as leis de Horton (1945), referente à quantidade e extensão dos canais, e a lei das áreas médias proposta por Schumm (1956).

Nas Figuras 37 e 38, são apresentados os gráficos com as projeções dos pontos das

variáveis $\mathrm{N}_{\mathrm{u}}, \mathrm{Lm}_{\mathrm{u}}$, e $\mathrm{Am}_{\mathrm{u}}$, estes pontos estão alinhados em direção da linha de tendência, porém com diferentes localizações, as quais refletem um comportamento que pode indicar possíveis anomalias na rede de drenagem. Para Horton (1945), o $\mathrm{N}_{\mathrm{u}}$ diminui com o aumento da ordem dos canais de forma regular, e a lei do comprimento médio dos canais de cada ordem é o inverso da lei dos números de canais, ou seja, o $\mathrm{Lm}_{\mathrm{u}}$ tende a aumentar com o aumento da ordem dos canais. O mesmo acontece para a lei das áreas médias de Schumm (1956), onde a Amu dos canais de cada ordem tende aumentar com o aumento da ordem.

$\mathrm{Na}$ bacia hidrográfica do rio Iguatemi observa-se uma diferença acentuada em relação aos valores de $\mathrm{Nu}, \mathrm{Lmu}$ e Amu a partir da $4^{\mathrm{a}}$ ordem, sendo que na $5^{\mathrm{a}}$ ordem as diferenças são mais acentuadas. Quando comparados com os valores da bacia hidrográfica do rio Piquiri observa-se que a bacia hidrográfica do rio Iguatemi, segundo as leis de Horton e Schumm, formam séries geométricas com grandes desvios. Na bacia hidrográfica do rio Piquiri os desvios são menores, mas há também evidência de distorções significativas na composição das séries geométricas. Conclui-se com esta análise que as redes de drenagem e suas áreas de drenagem direta apresentam certa semelhança para os 
canais de $1^{\mathrm{a}}, 2^{\mathrm{a}}$ e $3^{\mathrm{a}}$, sendo que a partir da $4^{\mathrm{a}}$ ordem as diferenças são mais acentuadas possivelmente em decorrência do controle lito-estrutural de cada bacia hidrográfica.

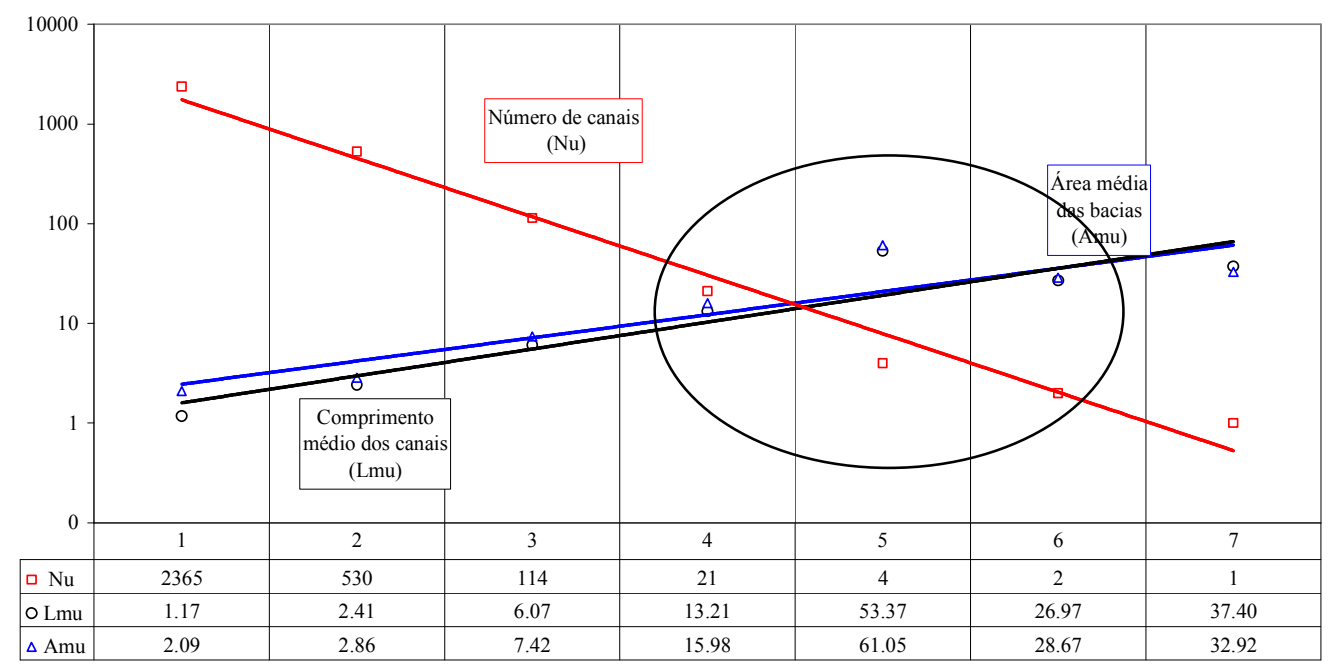

Figura 37 - Relação hierárquica x número de canais x extensão médias dos canais de cada x área média de drenagem dos canais por ordem de canais da bacia hidrográfica do rio Iguatemi - MS.

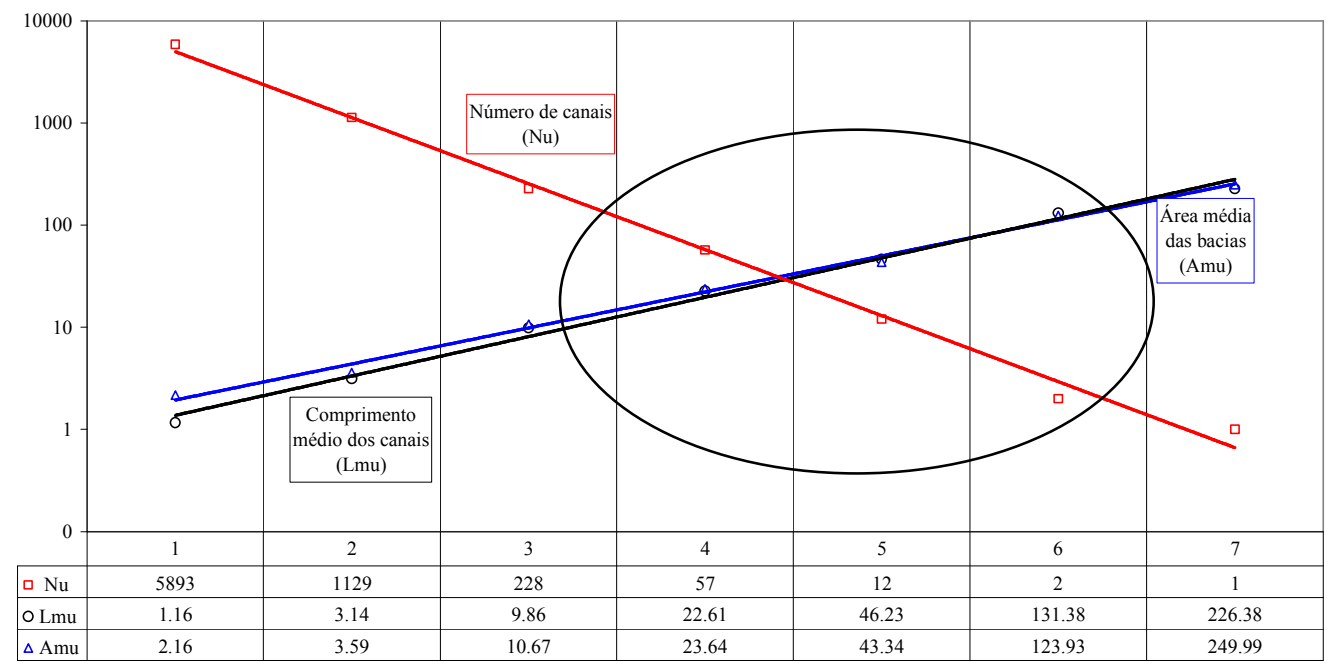

Figura 38 - Relação hierárquica x número de canais x extensão médias dos canais de cada $\mathrm{x}$ área média de drenagem dos canais por ordem de canais da bacia hidrográfica do rio Piquiri - PR. 
Nas Tabelas 4 e 5, estão sumarizados os valores de Rlm, Rb e Rlb das bacias hidrográficas dos rios Iguatemi e Piquiri. O maior valor de $\mathrm{R} \operatorname{lm}$ observado foi da relação dos comprimentos médios de $5^{\mathrm{a}}$ ordem da bacia hidrográfica do rio Iguatemi, o que indica um relevo mais dissecado. O menor valor ocorreu na relação dos canais de $6^{\mathrm{a}}$ com a $5^{\mathrm{a}}$ ordem. $\mathrm{Na} 7^{\mathrm{a}}$ ordem, notamos que na rede drenagem da bacia hidrográfica do rio Piquiri a Rlm foi superior em relação a bacia hidrográfica do rio Iguatemi.

Tabela 4 - Relação dos comprimentos (Rlm), relação de bifurcação $(\mathrm{Rb})$ e relação entre $\mathrm{R} l \mathrm{~m} / \mathrm{Rb}$ das ordens de canais da rede de drenagem da bacia hidrográfica do rio Iguatemi - MS.

\begin{tabular}{lccc}
\hline Ordem (u) & $\begin{array}{l}\text { Relação dos } \\
\text { comprimentos (RIm) }\end{array}$ & Relação de Bifurcação (Rb) & Relação entre RIm/ Rb \\
\hline $1^{\mathrm{a}}$ & ---------------- & 0,46 \\
$2^{\mathrm{a}}$ & 2,06 &,-- 46 & 0,54 \\
$3^{\mathrm{a}}$ & 2,52 & 4,65 & 0,40 \\
$4^{\mathrm{a}}$ & 2,18 & 5,43 & 0,77 \\
$5^{\mathrm{a}}$ & 4,04 & 5,25 & 0,25 \\
$6^{\mathrm{a}}$ & 0,51 & 2,00 & 0,69 \\
$7^{\mathrm{a}}$ & 1,39 & 2,00 & \\
\hline
\end{tabular}

Tabela 5 - Relação dos comprimentos (Rlm), relação de bifurcação $(\mathrm{Rb})$ e relação entre $\mathrm{R} l \mathrm{~m} / \mathrm{Rb}$ das ordens de canais da rede de drenagem da bacia hidrográfica do rio Piquiri - PR

\section{Relação dos}

Ordem (u) comprimentos (RIm) Relação de Bifurcação (Rb) Relação entre RIm/ Rb

\begin{tabular}{llll}
\hline $1^{\mathrm{a}}$ & & & \\
$2^{\mathrm{a}}$ & 2,70 & 5,22 & 0,52 \\
$3^{\mathrm{a}}$ & 3,14 & 4,95 & 0,63 \\
$4^{\mathrm{a}}$ & 2,23 & 4,00 & 0,57 \\
$5^{\mathrm{a}}$ & 2,04 & 4,75 & 0,43 \\
$6^{\mathrm{a}}$ & 2,84 & 6,00 & 0,47 \\
$7^{\mathrm{a}}$ & 1,72 & 2,00 & 0,86 \\
\hline
\end{tabular}


A relação de bifurcação $(\mathrm{Rb})$ tende a ter valor normalmente entre 2 a 5 , com tendência a aumentar quanto mais alongada for à bacia hidrográfica (BEAUTMONT, 1975). Desta forma, observa-se na Tabela 5, que a bacia hidrográfica do rio Piquiri tende a ser mais alongada em função das mensurações das relações de bifurcação da rede de drenagem. No entanto, a $\mathrm{Rb}$ de $5^{\mathrm{a}}$ ordem da bacia hidrográfica do rio Iguatemi é superior em relação ao valor de $\mathrm{Rb}$ da bacia hidrográfica do rio Piquiri, configurando-se uma anomalia da rede de drenagem da bacia hidrográfica do rio Iguatemi no trecho de drenagem e áreas de $5^{\mathrm{a}}$ ordem. Este fato está demonstrado nas Tabelas 6 e 7 das distribuições de áreas e relações de áreas médias das áreas de drenagem direta por ordem de canal.

Assim, de acordo como o que foi identificado no gráfico logaritmo do numero de canais, comprimentos médios e áreas médias, há a evidência de uma anomalia na rede de drenagem da bacia hidrográfica do rio Iguatemi a partir da $4^{\mathrm{a}}$ ordem de canais. Possivelmente esta anomalia está condicionada por descontinuidades estruturais da bacia hidrográfica, o que levou a formação de um cotovelo de drenagem no canal principal, onde este é classificado como de $5^{\mathrm{a}}$ ordem. Possivelmente este fato venha a ser uma evidência da ocorrência do processo de captura de fluvial. No entanto são necessários maiores detalhamentos para identificação de outras evidências, como por exemplo, vales abandonados. Segundo Christofoletti (1981), “a captura fluvial corresponde ao desvio das águas de um canal de uma bacia hidrográfica para outra, promovendo a expansão de uma drenagem em detrimento da vizinha". 
Tabela 6: Relação hierarquia, área média e relação entre áreas médias das áreas de drenagem direta por ordem de canal da bacia hidrográfica do rio Iguatemi, MS.

\begin{tabular}{|c|c|c|c|}
\hline Ordem (u) & $\begin{array}{c}\text { Área total das áreas de } \\
\text { drenagem direta para } \\
\text { cada ordem de canal } \\
(\mathrm{Au}) \\
\mathbf{k m}^{2} \\
\end{array}$ & $\begin{array}{c}\text { Áreas médias de } \\
\text { drenagem direta para } \\
\text { cada ordem de canal } \\
(\mathrm{Au}) \\
\mathbf{k m}^{\mathbf{2}} \\
\end{array}$ & $\begin{array}{c}\text { Relação entre áreas } \\
\text { médias (Ra) }\end{array}$ \\
\hline $1^{\mathrm{a}}$ & $4.941,23$ & 2,09 & \\
\hline $2^{\mathrm{a}}$ & $1.514,04$ & 2,86 & 1,37 \\
\hline $3^{\mathrm{a}}$ & 846,36 & 7,42 & 2,60 \\
\hline $4^{\mathrm{a}}$ & 335,61 & 15,98 & 2,15 \\
\hline $5^{\mathrm{a}}$ & 244,22 & 61,05 & 3,82 \\
\hline $6^{\mathrm{a}}$ & 57,34 & 28,67 & 0,47 \\
\hline $7^{\mathrm{a}}$ & 32,92 & 32,92 & 1,15 \\
\hline Total & $7.971,71$ & & \\
\hline
\end{tabular}

Tabela 7: Relação hierarquia, área média e relação entre áreas médias das áreas de drenagem direta por ordem de canal da bacia hidrográfica do rio Piquiri, PR.

\begin{tabular}{cccc}
\hline & $\begin{array}{c}\text { Área total das áreas de } \\
\text { drenagem direta para } \\
\text { cada ordem de canal } \\
(\mathbf{A u}) \\
\mathbf{k m}^{\mathbf{2}}\end{array}$ & $\begin{array}{c}\text { Áreas médias de drenagem } \\
\text { direta para cada ordem de } \\
\text { canal (Au) } \\
\mathbf{k m}^{\mathbf{2}}\end{array}$ & $\begin{array}{c}\text { Relação entre áreas } \\
\text { médias (Ra) }\end{array}$ \\
\hline $1^{\mathrm{a}}$ & $12.749,19$ & 2,16 & \\
$2^{\mathrm{a}}$ & $4.052,05$ & 3,59 & 1,66 \\
$3^{\mathrm{a}}$ & $2.432,85$ & 10,67 & 2,97 \\
$4^{\mathrm{a}}$ & $1.347,56$ & 23,64 & 2,22 \\
$5^{\text {a }}$ & 520,13 & 43,34 & 1,83 \\
$6^{\mathrm{a}}$ & 247,87 & 123,93 & 2,86 \\
$7^{\text {a }}$ & 249,99 & 249,99 & 2,02 \\
\hline & $\mathbf{2 1 . 5 9 9 , 6 4}$ & & \\
\hline
\end{tabular}

$\mathrm{Na}$ bacia hidrográfica do rio Iguatemi o comprimento do canal principal é de 204,831 km e na bacia hidrográfica do rio Piquiri o canal principal apresenta 589,230 km, e o gradiente de 1,8\%. A extensão do percurso superficial (Eps) da bacia hidrográfica do 
Iguatemi apresentou 748,078 m, enquanto na bacia hidrográfica do Piquiri a Eps foi de $812,547 \mathrm{~m}$ e o gradiente de 1,4\%. A bacia hidrográfica do rio Iguatemi apresenta um perímetro total igual a $707,112 \mathrm{~km}$, para uma área total de $7.971,71 \mathrm{~km}^{2}$ e comprimento máximo da bacia igual a $138 \mathrm{~km}$, e a bacia hidrográfica do rio Piquiri apresenta um perímetro total igual a $1.077,960 \mathrm{~km}$, para uma área total de $21.599,645 \mathrm{~km}^{2}$ e comprimento igual a $251 \mathrm{~km}$ (Tabela 8). De acordo com os valores levantados de Eps notamos que a bacia hidrográfica do rio Iguatemi apresenta uma maior capacidade de mobilização de materiais da superfície das vertentes em direção aos canais fluviais. Este comportamento também pode ser verificado pelo valor do gradiente do canal principal, o qual é superior no rio Iguatemi.

A densidade de drenagem (Dd) da bacia hidrográfica do rio Iguatemi foi calculada em $0.668\left(\mathrm{~km} / \mathrm{km}^{2}\right)$, o coeficiente de manutenção $(\mathrm{Cm})$ em 1.497,413 (m/m²), e o fator de forma (Kf), foi calculado em 0,419. Na bacia hidrográfica do rio Piquiri a densidade de drenagem (Dd) calculada foi $0,694\left(\mathrm{~km} / \mathrm{km}^{2}\right)$, o coeficiente de manutenção $(\mathrm{Cm})$ em $1.441,583\left(\mathrm{~m} / \mathrm{m}^{2}\right)$ e o fator de forma $(\mathrm{Kf})$ em 0,343 (Tabela 9). Notamos que o valor mais alto do fator de forma referente à bacia hidrográfica do Iguatemi lhe confere uma forma diferenciada em relação a forma da bacia do rio Piquiri. Em virtude destes valores, ambas as bacias são consideradas como alongadas. Estes resultados corroboram que as diferenças morfométricas das bacias hidrográfica estão condicionadas pelas variáveis de estado, ou estruturais, possivelmente em função de suas litologias, sendo que na bacia hidrográfica do rio Piquiri predominam as rochas basálticas e na bacia hidrográfica do rio Iguatemi há o predomínio de rochas sedimentares. 
Tabela 8: Análises morfométricas comparativas de parâmetros lineares das bacias hidrográficas Iguatemi e Piquiri.

\begin{tabular}{cccc}
\hline Bacia & $\begin{array}{c}\text { Comprimento do } \\
\text { canal principal } \\
\mathbf{L p}(\mathbf{k m})\end{array}$ & $\begin{array}{c}\text { Gradiente do canal } \\
\text { principal Gcp (\%) }\end{array}$ & $\begin{array}{c}\text { Extensão do percurso } \\
\text { superficial Eps ( m) }\end{array}$ \\
\hline Iguatemi & 204,831 & 1,8 & 748,078 \\
Piquiri & 589,230 & 1,4 & 812,547 \\
\hline
\end{tabular}

Tabela 9: Análises morfométricas comparativas de parâmetros areais das bacias hidrográficas Iguatemi e Piquiri.

\begin{tabular}{|c|c|c|c|c|c|c|}
\hline Bacia & $\begin{array}{l}\text { Área total } \\
\mathbf{A}\left(\mathbf{k m}^{2}\right)\end{array}$ & $\begin{array}{l}\text { Perímetro } \\
\text { P (km) }\end{array}$ & $\begin{array}{l}\text { Comprimento da } \\
\text { bacia Lb (km) }\end{array}$ & $\begin{array}{c}\text { Densidade de } \\
\text { drenagem } \\
\text { Dd }\left(\mathrm{km} / \mathrm{km}^{2}\right)\end{array}$ & $\begin{array}{c}\text { Fator de } \\
\text { Forma } \\
(\mathbf{K})\end{array}$ & $\begin{array}{c}\text { Coeficiente de } \\
\text { Manutenção } \\
\mathrm{Cm}\left(\mathbf{m}^{2} / \mathbf{m}\right)\end{array}$ \\
\hline Iguatemi & $7.971,71$ & 707,112 & 138 & 0,668 & 0,419 & $1.497,413$ \\
\hline Piquiri & $21.599,645$ & $1.077,960$ & 251 & 0,694 & 0,343 & $1.441,583$ \\
\hline
\end{tabular}

Quanto às variáveis hipsométricas (Tabela 10), a altitude mínima das bacias hidrográficas é igual a 229 m, mas a atitude máxima é maior na bacia hidrográfica do rio Piquiri. Observa-se que a amplitude da bacia hidrográfica do rio Piquiri é 2,7 vezes superior em relação a amplitude da bacia hidrográfica do rio Iguatemi, embora o gradiente do rio Iguatemi seja maior. Em relação à altitude média ou elevação média na bacia hidrográfica do rio Iguatemi, seu valor é menor que a altitude mediana. Por outro lado na bacia hidrográfica do rio Piquiri, a elevação média é maior que a altitude mediana. A comparação dos resultados referente à relação de relevo, permite constatar que a bacia hidrográfica do rio Piquiri possui um relevo mais dissecado que a bacia hidrográfica do Iguatemi. Isto ficou evidente no mapa de declividades apresentado anteriormente.

O índice de rugosidade (Ir) das bacias hidrográfica variou consideravelmente, resultado das diferenças na amplitude altimétrica, sendo que na bacia hidrográfica do rio Piquiri a Ir foi 2,8 vezes superior que o valor da bacia hidrográfica do rio Iguatemi, do ponto de vista da dissecação do relevo a bacia do rio Piquiri foi provavelmente a que mais 
esteve sujeita a ação dos processos erosivos (Tabela 10). Essa tendência, no que se refere à questão dos sedimentos em suspensão, indica que atualmente a bacia hidrográfica do rio Iguatemi provavelmente está mais vulnerável a mobilização dos sedimentos em direção aos canais fluviais.

Tabela 10: Análises hipsométricas comparativas de parâmetros das bacias hidrográficas Iguatemi e Piquiri.

\begin{tabular}{lcclllll}
\hline Bacia & $\begin{array}{c}\text { Altitude } \\
\text { mínima } \\
\text { (Alt.mim) }\end{array}$ & $\begin{array}{c}\text { Altitude } \\
\text { média (E) }\end{array}$ & $\begin{array}{c}\text { Altitude } \\
\text { máxima } \\
\text { (Alt.max) }\end{array}$ & $\begin{array}{c}\text { Altitude } \\
\text { mediana } \\
\text { (Alt.med) }\end{array}$ & $\begin{array}{c}\text { Amplitude } \\
\text { topográfica } \\
\text { (Hm) }\end{array}$ & $\begin{array}{c}\text { Relação } \\
\text { de relevo } \\
\text { (Rr) }\end{array}$ & $\begin{array}{c}\text { Índice } \\
\text { Rugosidade } \\
\text { (Ir) }\end{array}$ \\
\hline Iguatemi & 229 & 375 & 596 & 397 & 367 & 0,0027 & 245,089 \\
Piquiri & 229 & 564 & 1243 & 549 & 1014 & 0,0040 & 703,463 \\
\hline
\end{tabular}

Portanto, as análises lineares, areais e hipsométricas permitiram descrever em termos descritivos a potencialidade de cada bacia hidrográfica no que se refere a capacidade de mobilização e retenção dos sedimentos. 


\section{c) Análise do perfil longitudinal dos canais principais}

É possível visualizar na Figura 39, o trecho médio do rio Iguatemi onde este por sua vez é classificado como um canal de $5^{\text {a }}$ ordem. Notamos que neste trecho a ocorrência de um cotovelo de drenagem. É justamente neste trecho onde observamos que há a indicação de uma forte ruptura no perfil longitudinal (Figura 40), a qual possivelmente está relacionada com descontinuidades estruturais desta bacia hidrográfica.

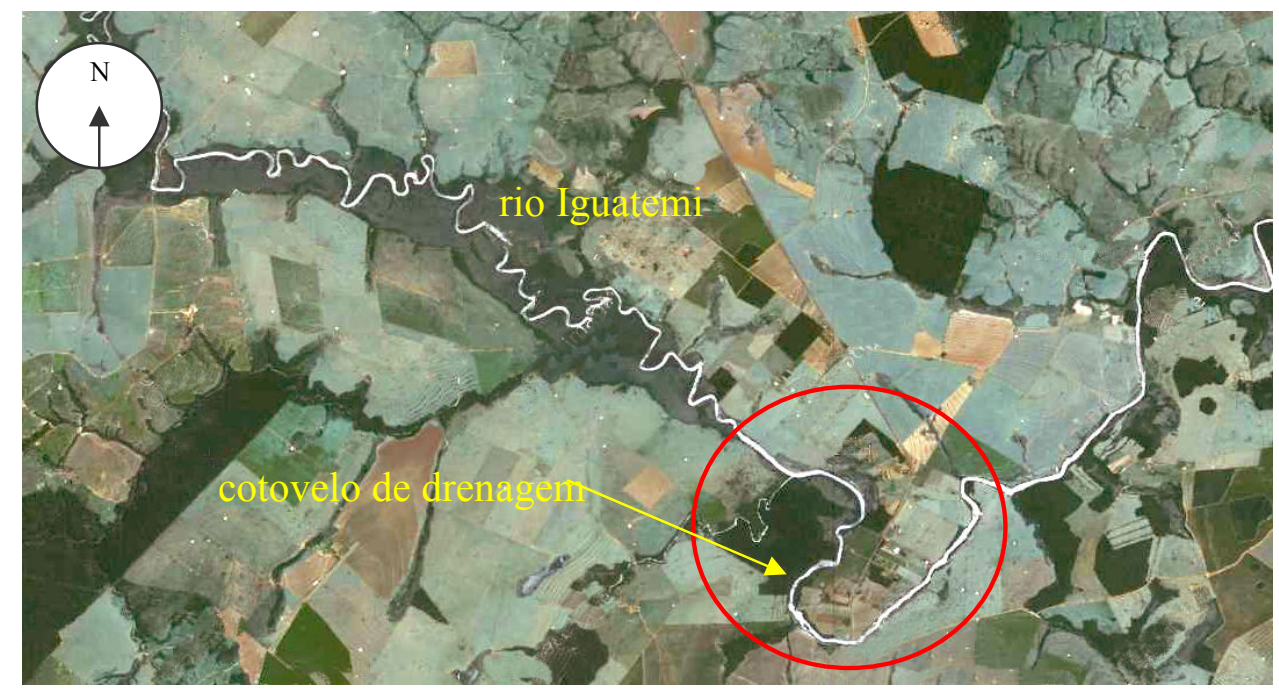

Figura 39 - Trecho médio do rio Iguatemi-MS e ocorrência de um cotovelo de drenagem.Org: Aguiar (2009).

Na Figura 40, o perfil longitudinal fluvial do rio Iguatemi mostra que há rupturas no segmento médio do canal principal, as quais estão associadas com as análises morfométricas apresentadas anteriormente, onde foi identificada a ocorrência de anomalias na rede de drenagem dos canais de $5^{\mathrm{a}}$ ordem. No alto curso do canal principal do rio Iguatemi ocorre algumas rupturas menos acentuadas, e no segmento de $5^{\mathrm{a}}$ para $6^{\mathrm{a}}$ ordem há a confluência do rio Puita que apresenta uma acentuada ruptura, uma vez que interrompe a seqüência progressiva do decréscimo do gradiente em direção jusante. Após este trecho o canal do rio Iguatemi apresenta-se estabilizado em direção a sua planície de inundação onde é classificado como um canal de $7^{\mathrm{a}}$ ordem. 


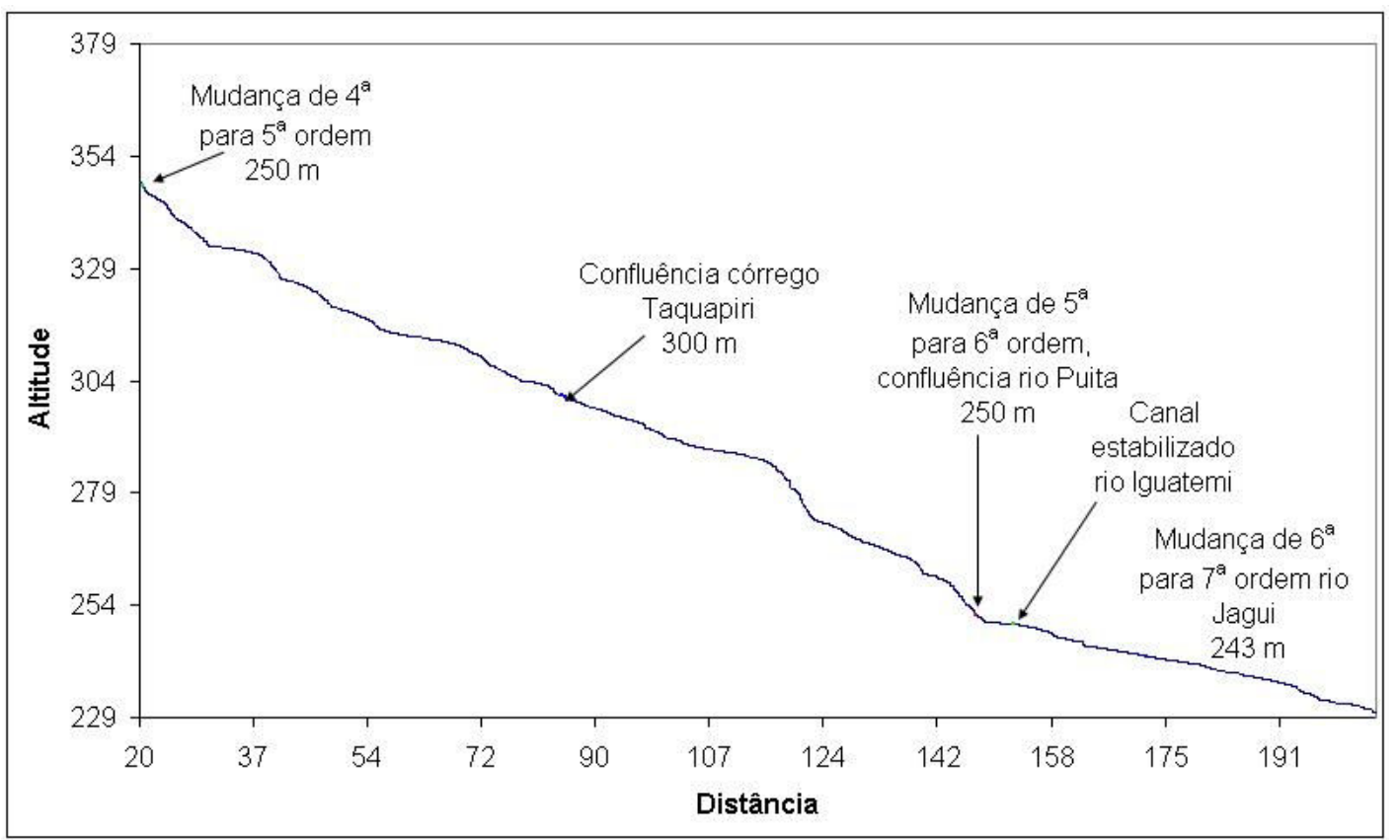

Figura 40: Perfil longitudinal do canal principal da bacia hidrográfica do rio Iguatemi - MS.

Org: Aguiar (2009).

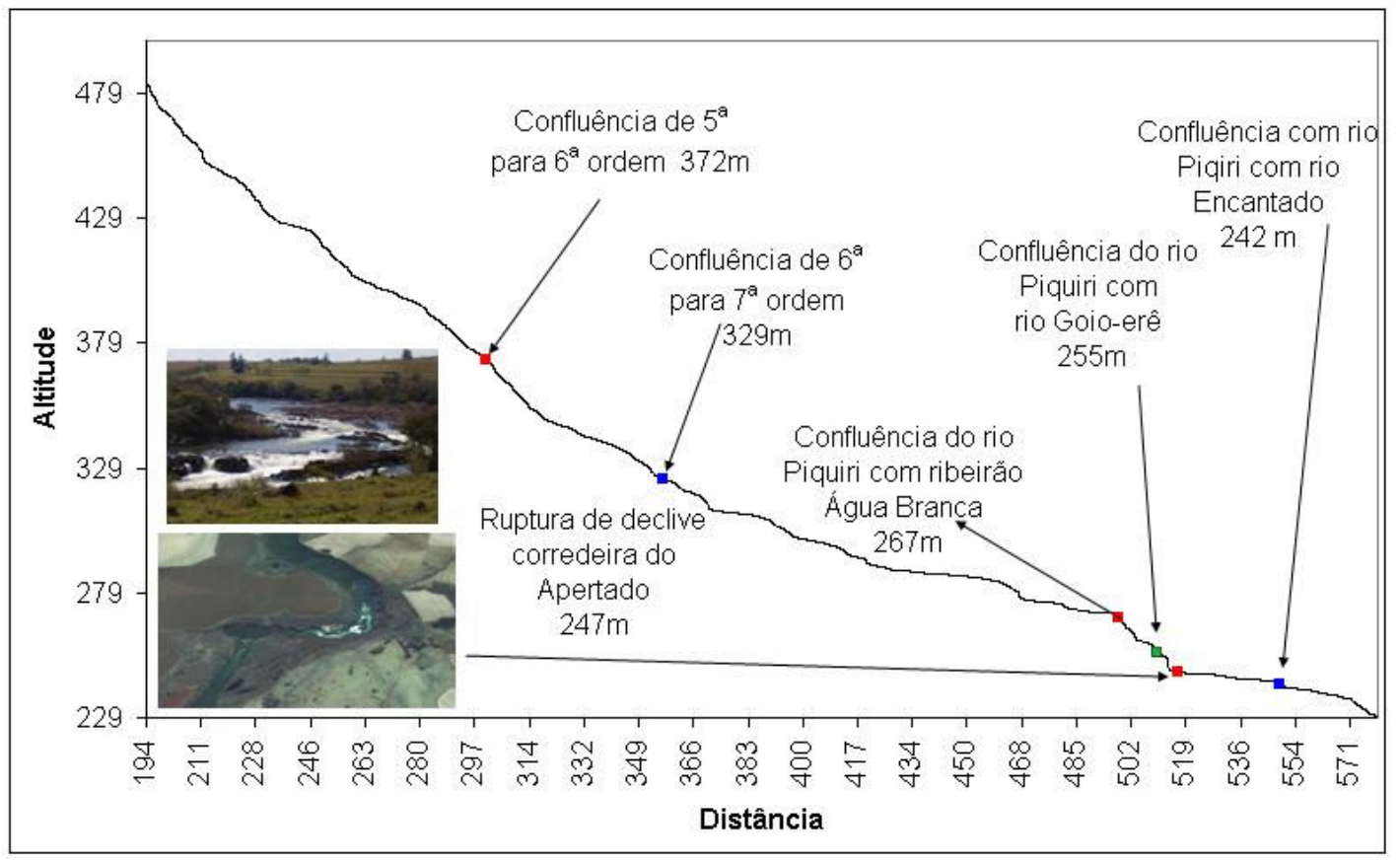

Figura 41: Perfil longitudinal do canal principal da bacia hidrográfica do rio Piquiri - PR Org: Aguiar (2009). 
Ao longo do perfil longitudinal dos rios Iguatemi e Piquiri, notamos que a morfologia dos canais analisados apresenta uma sucessão de patamares escalonados, marcados por rupturas negativas que atuam diretamente na natureza dos fluxos predominantes e transporte dos materiais, ou seja, há trechos onde ocorre a dissipação de energia e em outros a estocagem de materiais. Notamos que no rio Piquiri os patamares são mais extensos, e isto confere-lhe uma tendência a maior estocagem de sedimentos quando comparado com os patamares do rio Iguatemi.

\section{d) Análise comparativa das curvas hipsográficas e de volume}

O objetivo principal de criar as curvas hipsográfica e de volume foi possibilitar a comparação do potencial de geração de sedimentos das bacias hidrográficas pesquisadas, por meio do levantamento da integral hipsométrica (IH) e a integral volumétrica (IV). A IH expressa o volume do material existente antes do início do processo erosivo e a IV expressa o material remanescente frente os processos erosivos.

A diferença das integrais (IH-IV) resulta em um valor extremamente útil para análise do potencial erosivo das bacias hidrográficas, a diferença é considerada como a relação de material erodido de uma determinada bacia hidrográfica. Valores de $\mathrm{IH}$ acima de 0,6 ou $60 \%$ é representativo para bacias hidrográficas com alto potencial, valores entre $0,6-$ 0,35 (60\%-35\%) para bacias hidrográficas com médio potencial e abaixo de 0,35 ou 35\% para bacias hidrográficas com baixo potencial para produção de sedimentos. Os valores alto, médio e baixo foram relacionados com aqueles estabelecidos por Strahler (1952) para análise do desenvolvimento das bacias hidrográficas de acordo com o ciclo de erosão de Davis.

Na Figura 42, podemos verificar conjuntamente as curvas hipsográficas e de volume das bacias hidrográficas em questão, notamos que a IH da bacia hidrográfica do rio Iguatemi era de 0,4259 e a do Piquiri 0,3531. Em relação a IV, na bacia hidrográfica do 
Iguatemi temos o valor 0,03418 e na do Piquiri 0,2735. A relação IH-IV da bacia hidrográfica do Iguatemi apresenta valor maior que a bacia hidrográfica do rio Piquiri.

$\mathrm{Na}$ Figura 43, temos as curvas hipsográficas distribuídas em relação de porcentagem.

Observa-se que este tipo de representam não possibilita uma comparação tão eficiente quanto a distribuição em termos relativos.

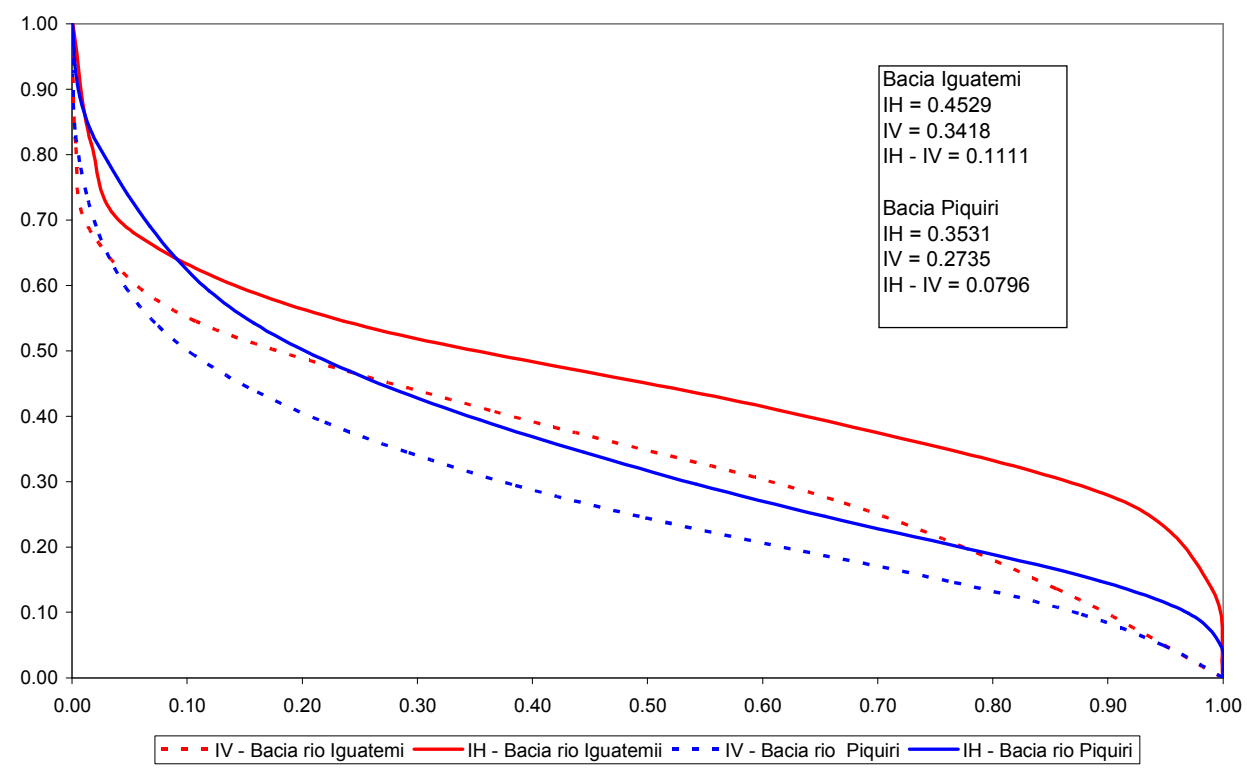

Figura 42: Curvas hipsográficas e de volume em termos relativos.

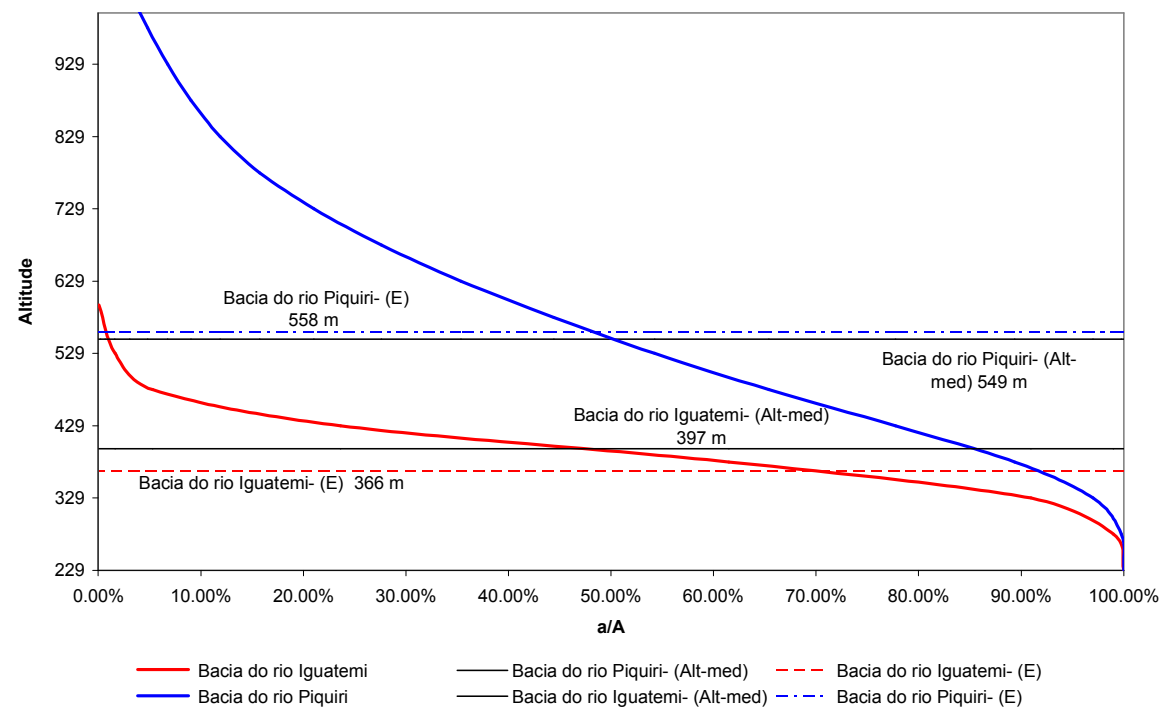

Figura 43: Curvas hipsográficas e de volume em termos percentuais. 
Conclui-se por meio da análise das curvas hipsográficas e volumétricas, em termos relativos, que a bacia hidrográfica do rio Piquiri apresenta um menor potencial de geração de sedimentos que a bacia hidrográfica do rio Iguatemi. Além disto, a forma da curva hipsográfica da bacia hidrográfica do rio Iguatemi é mais convexa, o que lhe confere o caráter de ter um maior potencial para produção de sedimentos. 


\subsection{Análises comparativas das variáveis hidrossedimentológicas}

Segundo Lima et al., $(2001,2003)$ a Pss média anual inferior a 70 pode ser considerada baixa, entre 70 a 175, moderada, entre 175 e 300, alta, e maior que 300, muito alta. Se convertermos estes valores para média diária temos que a Pss inferior a 0,19 pode ser considerada baixa, entre 0,19 a 0,47 , moderada, entre 0,47 e 0,82 alta, e maior que 0,82 , muito alta.

Levando em consideração os valores de Pss apresentados na comparação das bacias hidrográficas notamos por meio dos gráficos do tipo box-plot (Figuras 44 e 45), que no período 2002-2006 a bacia hidrográfica do rio Iguatemi apresentou valor mediano anual de Pss maior em relação aos valores da bacia hidrográfica do rio Piquiri praticamente todo o período, apenas no ano de 2005 a Pss foi menor. Em relação aos valores mínimos de Pss da bacia hidrográfica do rio Iguatemi estes foram mais altos em todo o período de análise. Os valores máximos analisados nestes gráficos foram de $0,398\left(\mathrm{t} / \mathrm{km}^{2} / \mathrm{dia}\right)$, considerado moderado, na bacia hidrográfica do rio Iguatemi e $0,417\left(\mathrm{t} / \mathrm{km}^{2} / \mathrm{dia}\right)$, considerado moderado, na bacia hidrográfica do rio Piquiri, enquanto o valor de mínimo da bacia hidrográfica do rio Piquiri foi $0,001\left(\mathrm{t} / \mathrm{km}^{2} / \mathrm{dia}\right)$, considerado baixo, e $0,018\left(\mathrm{t} . / \mathrm{km}^{2} / \mathrm{dia}\right)$, considerado baixo, na bacia hidrográfica do rio Iguatemi em 2005. 


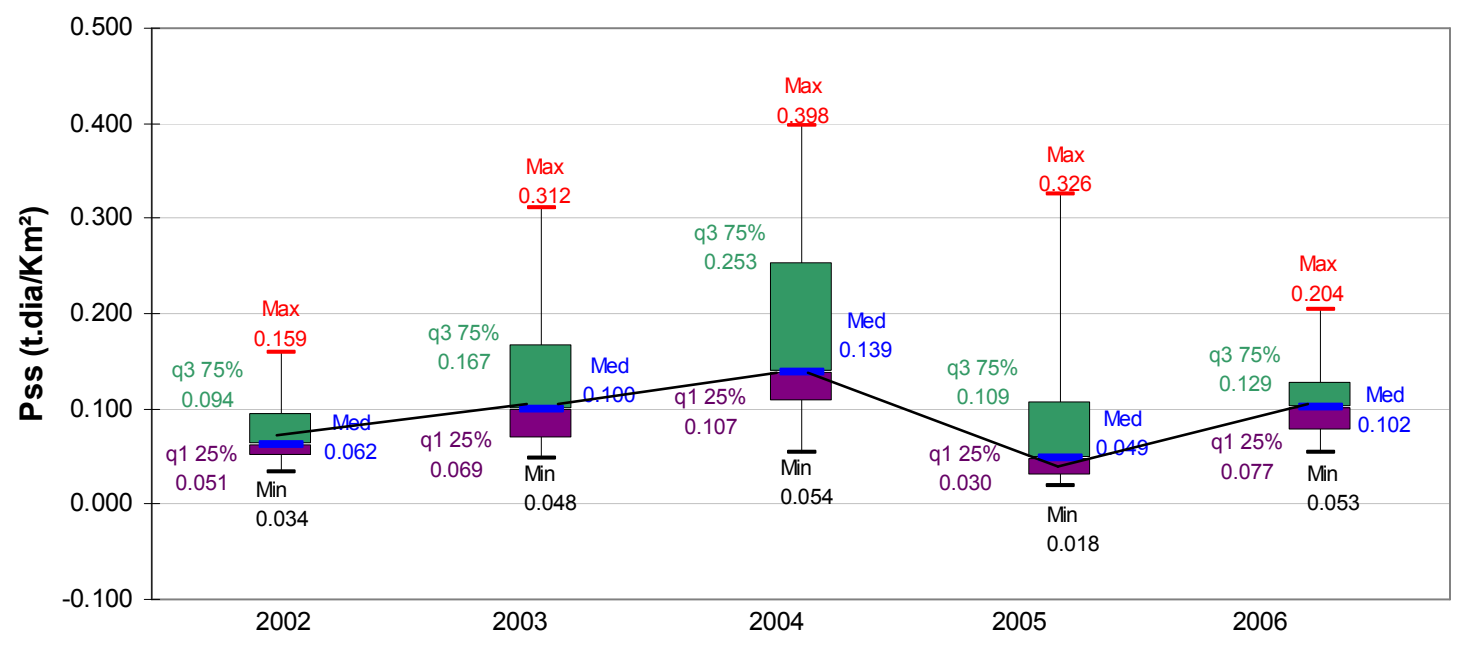

Figura 44 : Distribuição dos valores de produção específica de sedimentos em suspensão (Pss) máximo (Max); mínimo (Min); mediana (Méd), quartil 1 (q1), quartil 3 (q3), do período 2002-2006, bacia hidrográfica do rio Iguatemi-MS.

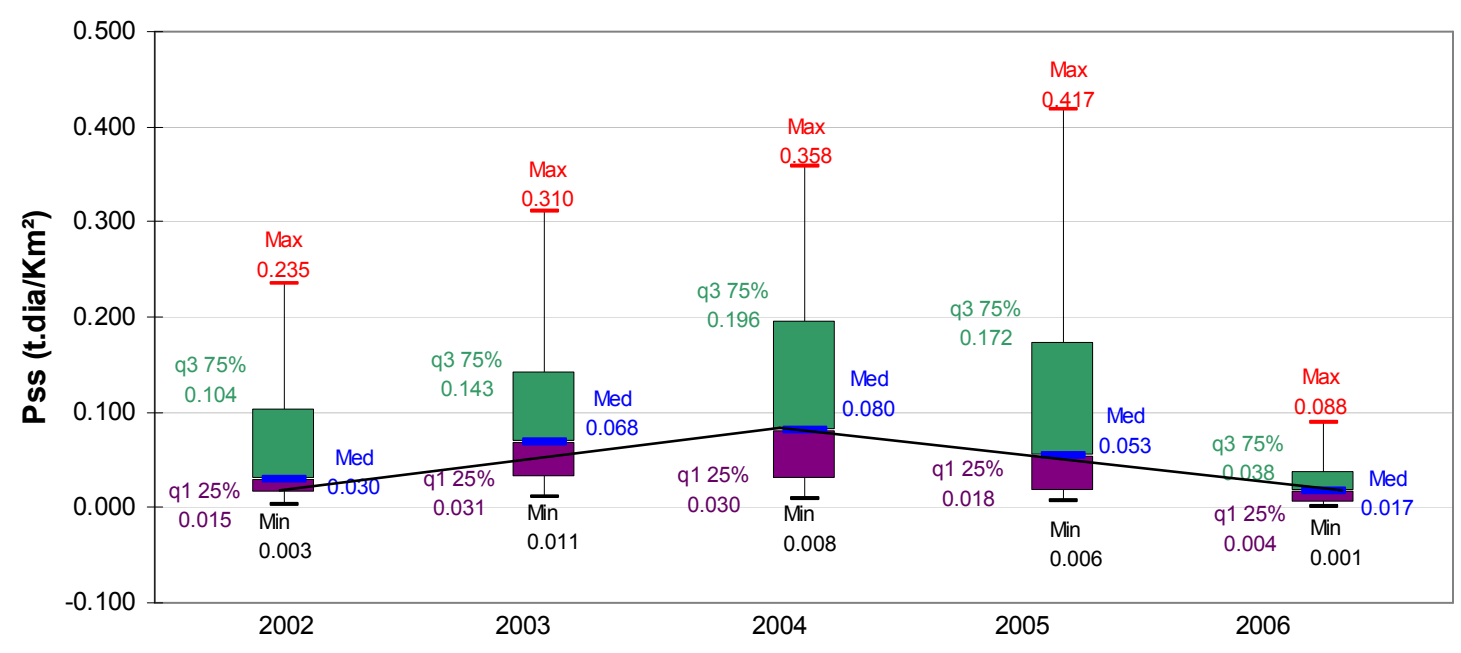

Figura 45: Distribuição dos valores de produção específica de sedimentos em suspensão Pss máximo (Max); mínimo (Min); mediana (Méd), quartil 1 (q1), quartil 3 (q3), do período 2002-2006, bacia hidrográfica do rio -PR.

Observa-se que em relação ao valor do $3^{\text {o }}$ quartil no ano de 2005 a bacia hidrográfica do rio Piquiri apresentou valores máximos, q3, mediana e q1 maiores que a bacia hidrográfica do rio Iguatemi, mas no ano de 2006 estes valores tiveram um forte 
decréscimo e todos se apresentaram inferiores quando comparados com os valores da bacia hidrográfica do rio Iguatemi. Um dos motivos que influenciaram este comportamento está relacionado com o decréscimo da vazão média neste ano.

Considerando a classificação de Lima et, al., (2001,2003), a Pss das bacias hidrográficas é considerada baixa em termos de valores medianos. Se considerarmos os gráficos de valores diários de Pss de todo o período, sem o descarte de outliers (Figura 46), observamos que há períodos em que o Pss é moderada, alta e muito alta. Em todos os gráficos do período o valor mínimo de Pss é superior na bacia hidrográfica do rio Iguatemi, visualmente podemos notar as diferenças entre as linhas de valores médios diários de Pss, os quais são mais expressivos entre os meses de outubro, novembro e dezembro, quando ocorrem picos dos valores de Pss, principalmente na bacia hidrográfica do rio Piquiri (Figura 46). 

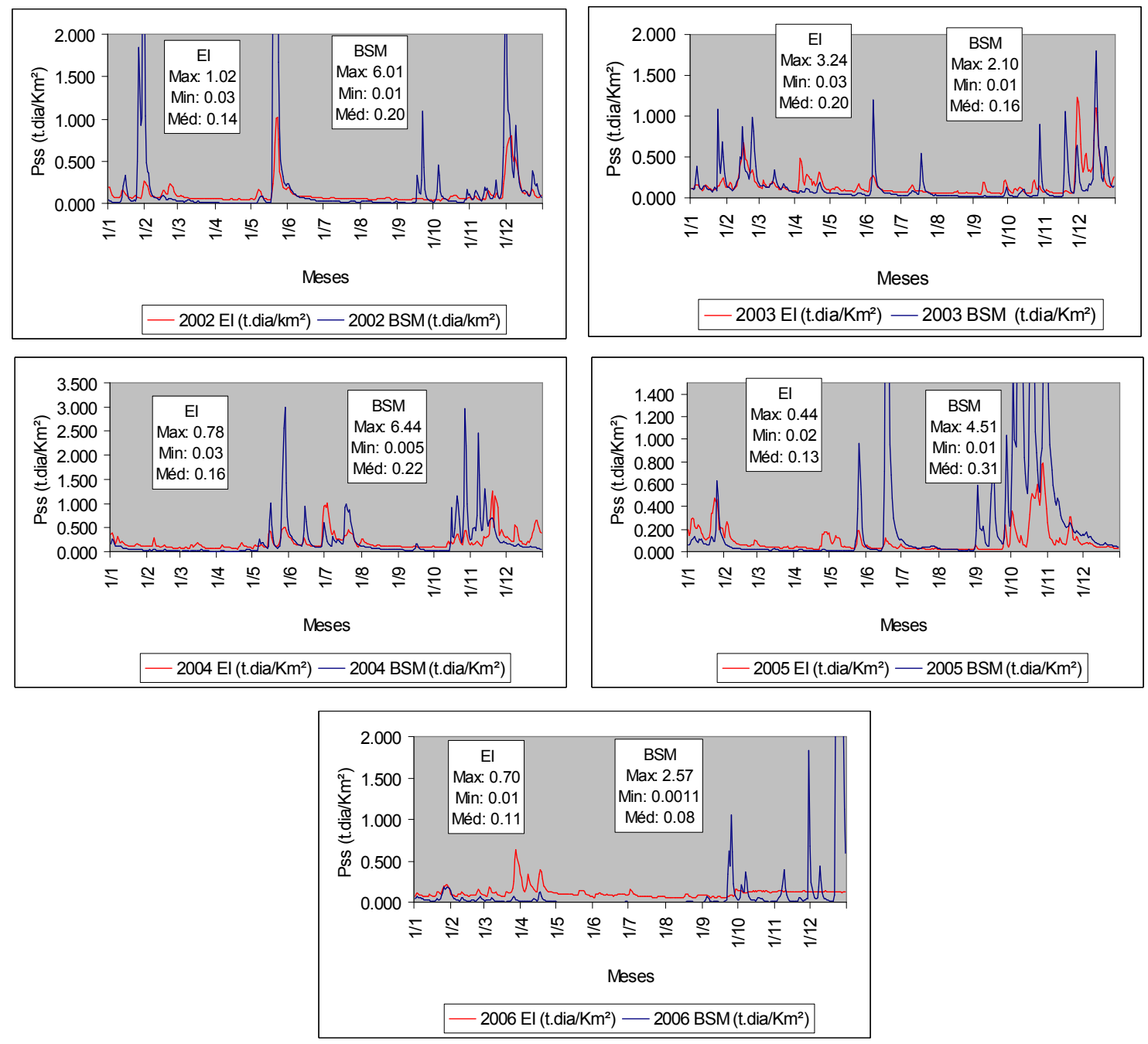

Figura 46: Gráficos das médias diárias de Pss das bacias hidrográficas analisadas.

As análises hidrossedimentológicas demonstram que o potencial de produção especifica de sedimentos em suspensão da bacia hidrográfica do rio Iguatemi é muito significativo em relação ao potencial da bacia hidrográfica do rio Piquiri, mesmo tendo a bacia do rio Iguatemi a área e descarga líquida menor. Também notamos que a bacia hidrográfica do rio Piquiri apresenta valores máximos bem contrastantes em relação ao conjunto de observações da análise comparativa. Isto porque nos gráficos de correlação das médias mensais do período, referente a P $(\mathrm{mm}), \mathrm{N}(\mathrm{m}), \mathrm{Css}(\mathrm{mg} / \mathrm{l})$ e $\mathrm{Q}\left(\mathrm{m}^{3} / \mathrm{s}\right)$, com a Pss 
$\left(\mathrm{t} / \mathrm{km}^{2} /\right.$ dia) como uma variável dependente, no período de análise a estação de monitoramento Balsa Santa Maria apresentou média de Pss extremamente distantes do conjunto de valores calculados (Figura 47). Isto foi decorrente de um evento extremo possivelmente correlacionado ao valor máximo de Pss constatado no mês de outubro de 2005 (APÊNDICE B).

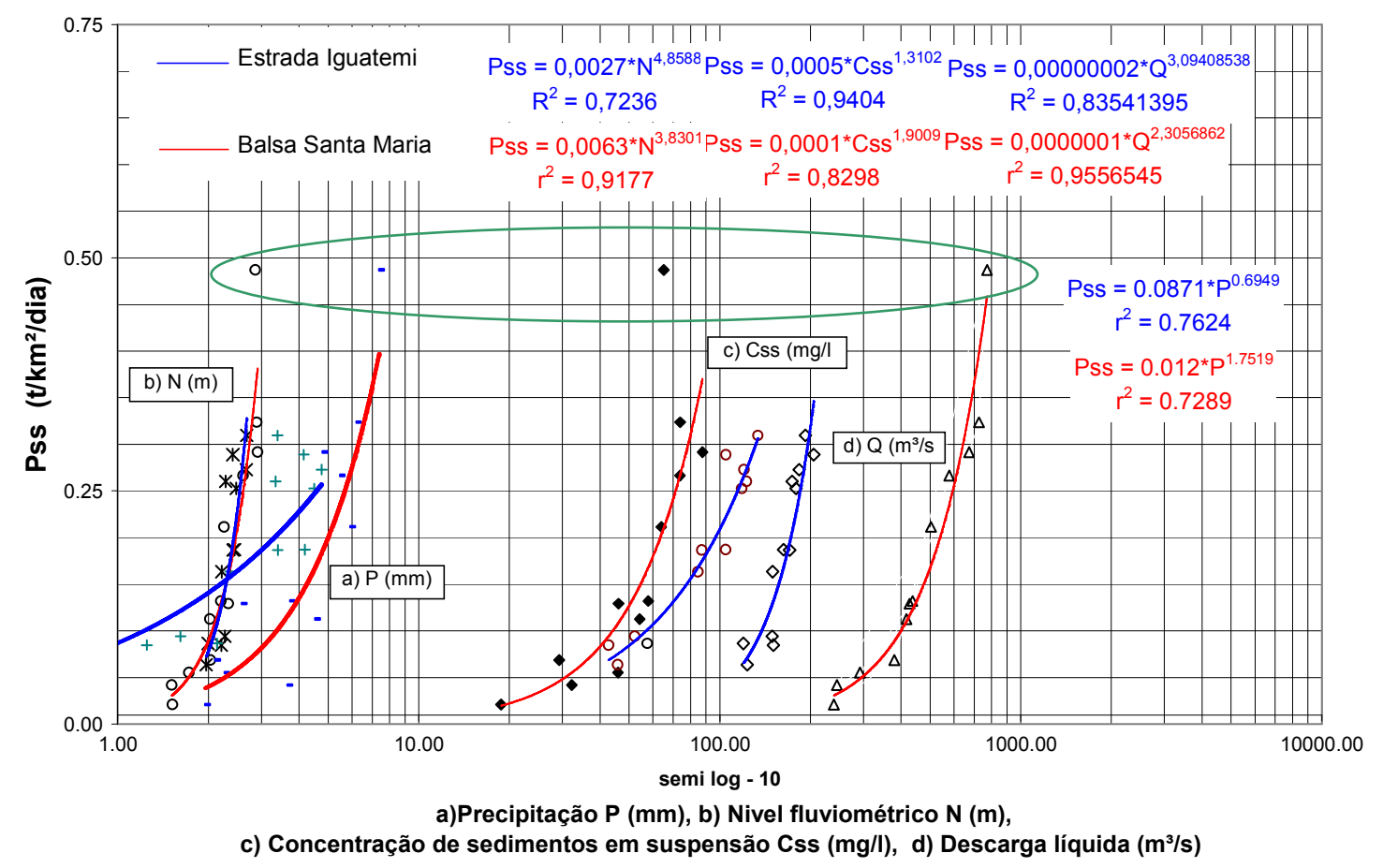

Figura 47: Correlações das variáveis hidrossedimentológicas.

Ambas as bacias hidrográficas apresentaram correlação positiva com índice de determinação $\left(\mathrm{r}^{2}\right)$ superiores a 70\%. Observamos também por meio da leitura da Figura 47, que as correlações de $\mathrm{Q}\left(\mathrm{m}^{3} / \mathrm{s}\right)$ do rio Piquiri estão distante da linha de tendência da bacia hidrográfica do rio Iguatemi, isto mostra que esta possui uma resposta diferenciada para o aumento de $\mathrm{Q}\left(\mathrm{m}^{3} / \mathrm{s}\right)$, no entanto a linha de tendência referente a Css $(\mathrm{mg} / \mathrm{l})$ da estação de monitoramento referente a bacia hidrográfica do rio Iguatemi está a frente da linha referente a estação da bacia hidrográfica do rio Piquiri, isto é um indicador de que a Css do 
rio Iguatemi é maior. Podemos constatar isto na Tabela 11, referente aos valores médios mensais de Css no período 2002 -2006.

De acordo com Lima et al. (2003), Css inferiores a 50mg/1 podem ser classificadas como muito baixas, de 50 a $100 \mathrm{mg} / \mathrm{l}$, baixas, de 100 a $150 \mathrm{mg} / \mathrm{l}$, moderadas, de 150 a 300 mg/l, altas e acima de $300 \mathrm{mg} / 1$, muito altas. Considerando esta classificação, entre outubro e janeiro, na estação Estrada Iguatemi as concentrações variaram de baixa a moderada, e na estação Balsa Maria foram baixas.

Tabela 11: Comparação dos valores médios mensais de Css no período 2002 -2006 nas estações de monitoramento das bacias hidrográficas analisadas.

\begin{tabular}{lcc}
\hline & Estrada Iguatemi - rio Iguatemi - MS & Balsa Santa Maria - rio Piquiri - PR \\
\hline Jan & Css (mg/l) & Css (mg/l) \\
Fev & 118.307 & 73.776 \\
Mar & 92.716 & 51.128 \\
Abr & 95.059 & 39.563 \\
Mai & 122.734 & 32.252 \\
Jun & 90.574 & 63.898 \\
Jul & 52.155 & 46.065 \\
Ago & 42.724 & 29.280 \\
Set & 61.225 & 18.762 \\
Out & 68.814 & 69.984 \\
Nov & 100.831 & 74.936 \\
Dez & 131.275 & 86.348 \\
\hline
\end{tabular}

Na Figura 48, observa-se que as curvas de valores médios mensais seguem uma mesma tendência em relação ao aumento e diminuição da Css, no entanto entre os meses de fev/mar e jul/ago este comportamento é diferente, possivelmente em função das chuvas concentradas e longos períodos de estiagem. Em relação as semelhanças das curvas de Css observa-se que as bacias hidrográficas apresentam um forte controle de variáveis dinâmicas muito parecidas. 


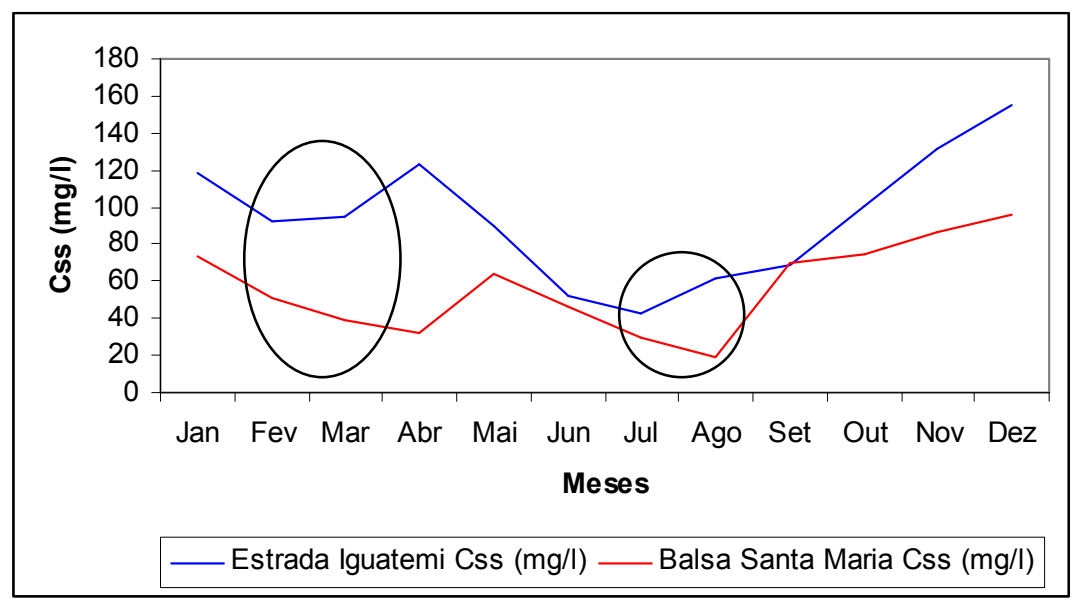

Figura 48: Comparação das médias anuais das concentrações de sedimentos em suspensão das estações de monitoramento Estrada Iguatemi e Balsa Santa Maria no período 2002-2006.

No dia 28/01/2004, o satélite QuickBird coletou uma cena que cobre a desembocadura dos rios Iguatemi e Piquiri, e por meio da interpretação visual da imagem capturada neste dia notamos que na composição colorida 321/RGB, a intensidade da cor da água do rio Iguatemi é mais intensa que a cor da água do rio Piquiri, isto é um indicador de uma maior concentração de sedimentos em suspensão no rio Iguatemi (Figura 49). Para fins de constatação, foi realizado a comparação das mensurações de Css (mg/l), NTU, Q (m³/s), $\mathrm{N}(\mathrm{m})$, Qss (t.dia), e Pss ( $\left.\mathrm{t} / \mathrm{km}^{2} / \mathrm{dia}\right)$, referente aos dias mais próximos do momento de passagem do satélite QuickBird.

Quadro 6: Análise comparativa de parâmetros hidrossedimentológicos das estações de monitoramento Estrada do Iguatemi e Balsa Santa Maria.

Estrada do Iguatemi

\begin{tabular}{|c|c|c|c|c|c|c|c|}
\hline $\mathrm{A}=7.971,71$ & & Css & (NTU) & Q & N & Qss & \multicolumn{1}{c|}{ Pss } \\
\hline $26 / 01 / 04$ & $9: 00$ & 112,75 & 102,00 & 150,53 & 2,16 & $1.466,40$ & 0,18395 \\
\hline $30 / 01 / 04$ & $9: 00$ & 91,41 & 65,00 & 138,91 & 2,08 & 1.097 .11 & 0,137625 \\
\hline
\end{tabular}

Balsa Santa Maria

\begin{tabular}{|c|c|c|c|c|c|c|c|}
\hline $\mathrm{A}=21.599,645$ & & Css & (NTU) & Q & N & Qss & Pss \\
\hline $26 / 01 / 04$ & $18: 00$ & 40,90 & 20,00 & 300,70 & 1,81 & $1.062,58$ & 0,0491 \\
\hline $29 / 01 / 04$ & $15: 00$ & 27,74 & 14,00 & 281,00 & 1,71 & 673,43 & 0,0311 \\
\hline
\end{tabular}


Observa-se que o nível fluviométrico na estação do rio Iguatemi variou de 2,16 m a 2,08 e no rio Piquiri 1,81 e 1,71 m, já a descarga líquida na estação do rio Iguatemi variou de 150,53 a $138,91 \mathrm{~m}^{3} / \mathrm{s}$ e do rio Piquiri de 300,70 a $281,00 \mathrm{~m}^{3} / \mathrm{s}$, portanto a descarga líquida da estação do rio Piquiri é superior em relação a descarga líquida da estação de monitoramento da bacia hidrográfica do rio Iguatemi. A descarga sólida de sedimentos em suspensão na estação do rio Piquiri houve a variação entre 1.062,58 e 673,43 (t/dia) e na bacia hidrográfica do rio Iguatemi 1.466,40 e 1.097.11 (t/dia) Também podemos constatar a Css, NTU e Pss superiores na estação referente à bacia hidrográfica do rio Iguatemi. Tal comportamento pode estar relacionado possivelmente ao gradiente do canal principal do rio Piquiri que é menor em relação ao do rio Iguatemi, ou, a morfologia do perfil longitudinal do rio Piquiri tem contribuído por meio de sucessivos patamares a estocagem de sedimentos ao longo do canal principal.

Portanto, constatamos que a bacia hidrográfica do rio Iguatemi teve uma Pss superior em relação a bacia hidrográfica do rio Piquiri, mesmo tendo descarga líquida diária e média da precipitação no mês de janeiro menor em relação a bacia hidrográfica do rio Piquiri (APENDICE B). A precipitação média mensal na estação de monitoramento da bacia hidrográfica do rio Piquiri no mês de janeiro de 2004 foi de 4,2 mm e na estação do rio Iguatemi 2,0 mm, isto mostra que as chuvas foram mais intensas na bacia hidrográfica do rio Piquiri, mas o transporte de sedimentos em suspensão da bacia mostrou ser mais proeminente na bacia hidrográfica do rio Iguatemi. 


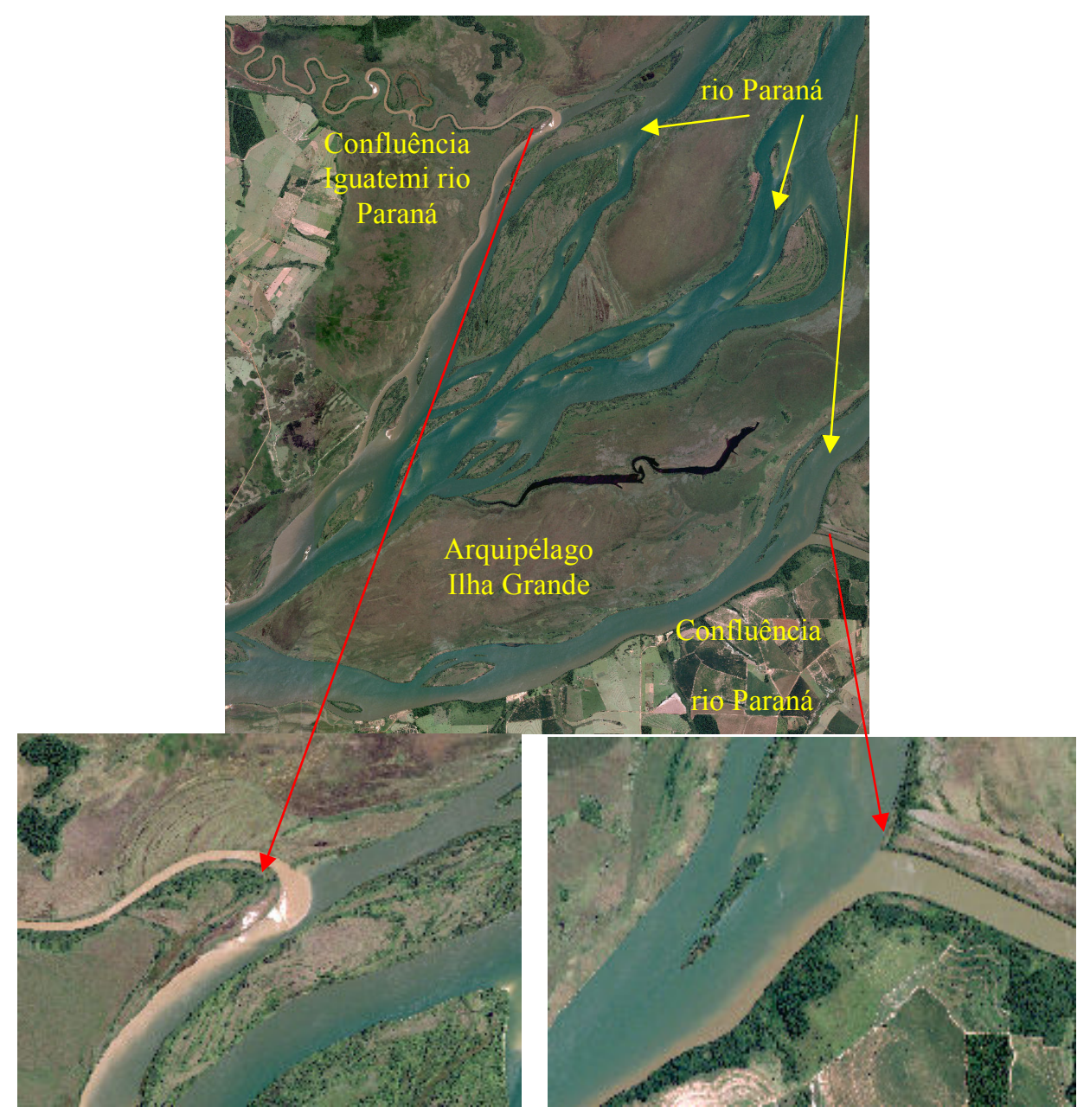

Figura 49: Imagem capturada pelo satélite QuickBird em 28/01/2004. Fonte: Digital Globe. Org: Aguiar (2009)

$\mathrm{O}$ fato de que nos dias analisados anteriores e posteriores em relação à passagem do satélite, o nível fluviométrico tenha sido maior na bacia hidrográfica do rio Iguatemi, pode possivelmente estar relacionado com a variável de forma da bacia que apresentou conforme exposto anteriormente o valor de 0,419 . Na bacia hidrográfica do rio Piquiri o valor do fator de forma calculado foi de 0,343 , isto significa que quanto maior o valor do fator de forma mais arredonda será a forma da bacia, com isto concluímos que a bacia hidrográfica do rio Iguatemi é mais arredondada e possui uma maior probabilidade das chuvas se concentrarem em seu interior de forma a influenciar a variação do nível fluviométrico. Em 
relação a Q notamos que no rio Piquiri seu valor é aproximadamente 2 vezes superior em relação a Q do rio Iguatemi. Portanto a variabilidade hidrossedimentológica das bacias hidrográficas analisadas decorre do ajustamento dos parâmetros hidrogeomorfológicos e hidrossedimentológicos. 


\section{CONSIDERAÇÕES FINAIS}

O objetivo desta pesquisa foi efetuar análises geomorfológicas e hidrossedimentológicas para caracterização das diversas influências atuantes no aporte de sedimentos em suspensão de bacias hidrográficas dos rios Iguatemi e Piquiri em direção ao rio Paraná e consequentemente ao reservatório de Itaipu. As técnicas de análise espacial introduzidas com o geoprocessamento proporcionaram no desenvolvimento deste estudo de bacias hidrográficas uma maior facilidade para a integração e a espacialização dos dados, o que possibilitou levantar um grande número de parâmetros morfométricos, reduzindo a subjetividade nos procedimentos de análise. A possibilidade de analisar informações morfométricas de diferentes bacias hidrográficas bem como inserir conhecimento de análises geomorfológicas, demonstrou que o emprego do geoprocessamento é uma ferramenta extremamente útil para fins de análises comparativas de bacias hidrográficas.

Os resultados demonstraram o potencial do emprego das variáveis hidrogeomorfológicas e hidrossedimentológicas para análises dos processos dinâmicos da superfície terrestre e seus fluxos, os quais exercem forças destrutivas e acumulativas nas camadas superiores do relevo resultando na alteração e deslocamento dos materiais superficiais em direção aos canais fluviais. Sob o ponto de vista das análises hidrogeomorfológicas as mensurações subsidiaram a análise de diferentes variáveis morfométricas que, por sua vez, permitiram interpretações sobre processos fluviais predominantes e o reconhecimento da distribuição espacial das particularidades de cada sistema em análise.

Ambas as metodologias conduziram a execução dos objetivos propostos, tendo os mesmos sido alcançados por meio de diferentes técnicas de análise, notamos que as variáveis analisadas das bacias hidrográficas dos rios Iguatemi e Piquiri estão possivelmente controladas pelas condições de ordem geológica e estrutural. Isto é bastante notório no desenvolvimento fisiográficos das bacias hidrográficas analisadas, tanto que na 
bacia do rio Iguatemi ocorre um distúrbio muito significativo nos canais de $5^{\mathrm{a}}$ ordem, e a (Pss) apresenta-se mais atuante nesta bacia, onde as rochas que formam seu substrato são mais permeáveis que as da bacia do rio Piquiri. Também notamos neste que os perfis longitudinais dos canais principais das bacias hidrográficas analisadas apresentam patamares escalonados que influenciam na natureza dos fluxos predominantes, estocagem e transporte dos materiais. Em relação a análise das curvas hipsográficas e de volume, a representação relativas das áreas demonstrou por meio da comparação das curvas referentes as bacias hidrográficas em questão, que a bacia hidrográfica do rio Iguatemi apresenta um maior potencial para produção de sedimentos em decorrência dos processos erosivos.

Os resultados da Pss apresentaram-se coerentes, com valores significativos de mobilização de sedimentos em suspensão para ambas as bacias hidrográficas analisadas, principalmente ao analisar a Pss no período de que o satélite QuickBird coletou uma imagem sob as áreas das desembocaduras das bacias hidrográficas. A imagem coleta possibilitou a interpretação visual da cor da água nas desembocaduras dos rios principais das bacias analisadas, onde ficou bem evidente a maior concentração de sedimentos em suspensão no rio Iguatemi. Desta forma notamos que são necessários estudos específicos para implantação de projetos de planejamento conservacionista do uso do solo, de forma a minimizar a mobilização dos materiais superficiais e os procedimentos adotados neste estudo podem subsidiar estudos especulativos, voltados a criação de modelos matemáticos para identificação de áreas de riscos em relação a produção de sedimentos. Conclui-se que são necessários estudos com nível maior de detalhamento, como por exemplo, mapeamentos geológicos e geomorfológicos de detalhe nas escalas entre 1:25.000 e 1:50.000, além do uso de imagens de satélite multiespectrais para análise espacial das áreas fontes de sedimentos. Também notamos que é fundamental por parte da Itaipu Binacional a implantação de novos postos de monitoramento hidrossedimentológico ao longo dos canais principais das bacias hidrográficas analisadas, no intuito de aprofundar a compreensão da 
mobilização dos sedimentos em suspensão, levando se em consideração a morfologia dos perfis longitudinais dos rios principais das bacias de contribuição do reservatório de Itaipu. 


\section{BIBLIOGRAFIA}

AGENDA 21 Brasileira - Bases para discussão.Brasília: MMA/PNUD, 2000.

ALLEN, P. A. Earth surface processes. Oxford: Editorial Offices. 1997.

ABRAHAMS, A. D. Channel networks: a geomorphological perspective. Water Resources Research, v. 20, n 2, 1984. p. $161-168$.

ABREU, A. A. Surell e as leis da morfologia fluvial. São José do Rio Preto, UNESP, IBILCE. (Craton \& Intracraton: escritos e documentos, 7). 1980. 13 p.

ABREU, A. A. Análise geomorfológica: reflexão e aplicação uma contribuição ao conhecimento das formas de relevo no Planalto de Diamantina. Tese de Livre docência. São Paulo: FFLCH - USP, 1982.

AB'SABER, A. N. Um conceito de geomorfologia a serviço das pesquisas sobre o Quaternário. Geomorfologia. São Paulo - Inst. de Geografia - USP/SP, n. 18, 1969. 23p.

AGUIAR, A.M,; GOMES, L.C. Modificações hidrogeomorfológicas avaliadas por sensoriamento remoto e sua influência no ambiente aquático do reservatório de ITAIPUPR-BRASIL In: Simpósio Nacional de Geomorfologia - Goiânia. Regional Conference on Geomorphology, 6, 2006. Anais eletrônicos V. II.

BATES, R.L, JACKSON, J.A. (Eds). Glossary of Geology. $3^{\text {a }}$ ed. Alexandria: American Geological Institute, 1987. 788p.

BEAUMONT, P. Hydrology. In: WHITTON, B. A. (Ed.). River ecology. Berkeley: University of California Press, 1975. p. 1-38

BERTALANFFY, L. VON. An Outline of General Systems Theory. In British Journal Of Phylosophy Of Science. No 1, London. 1950. p.139-164.

BERTRAND, G. Paysage et geographie physique globale: esquisse méthodologique. Rev.Géograph. Pyrénées et du Sud-Ouest, 39(3). Toulouse, 1968. p. 249-272.

BRASIL. Ministério das Minas e Energia. Secretaria Geral. Projeto RADAMBRASIL: (Levantamento de Recursos Naturais, v. 28). Folha SF. 21 (Campo Grande). Rio de Janeiro. 1982. $412 \mathrm{p}$.

CÂMARA, G. MEDEIROS, J. S. DE; Curso "Geoprocessamento para Projetos Ambientais". Disponível em: <http://www.dpi.inpe.br/gilberto/tutoriais/gis_ambiente/>. Acesso em: 6 fev.2009.

CAMPOS, J. B; SOUZA, M.C. Vegetação. In Vazzoler, A.E.A. de M.; Agostinho A.A.; Hahn, N.S (Eds). A Planície de Inundação do Alto Rio Paraná: Aspectos físicos,biológicos e sócio-econômicos.- EDUEM: Maringá. 1997. p.331-338; 
CARVALHO, N. O. Hidrossedimentologia prática. Rio de Janeiro: CPRM. 1994. 372 p.

CHORLEY, R. J. SCHUMM, S. A.; SUGDEN, D. E. Geomorphology. New York: Methuen \& Co. 1985.

CHORLEY, R.J. MORLEY, L.S.D. A simplified approximation for the hipsometric integral. Journal of Geology,Chicago, 67: 1959. p. 566-571.

CHRISTOFOLETTI, A. Análise morfométrica de bacias hidrográficas no Planalto de Poços de Caldas. Tese (Livre Docência) - Universidade Estadual Paulista, Rio Claro. 1970.

CHRISTOFOLETTI, A. Geomorfologia. São Paulo, Universidade de São Paulo. 1974. $149 \mathrm{p}$.

CRISTOFOLETTI, A. Geomorfologia Fluvial, Vol.1, Canal Fluvial, Editora Edgard Blücher Ltda, 1981.

CLARK, M. J. Geomorphology in Coastal Zone Management. Geography. London:

Mansell. 63. 1978. p. $273-282$.

COATES, D. R. Editor. Environmental Geomorphology and Landscape Conservationl. Pensylvania, Urban Areas, Vol. II, Dowden, Huctchinson e Ross, Inc. Stroudsbarg. 1974.

CPRM. Geologia, Tectônica e Recursos Minerais do Brasil: Sistema de Informações Geográficas - SIG e Mapas na escala 1:250.000.- Brasília. 2001.

CRÓSTA, A. P. Processamento digital de imagens de sensoriamento remoto. Campinas, SP:IG/UNICAMP. 1993. 170p.

CUNHA, C.M.L. A. Cartografia do Relevo no Contexto da Gestão Ambiental. Tese (Doutorado em Geociências e Meio Ambiente) - Instituto de Geociências e Ciências Exatas, UNESP, Rio Claro-SP. 2001.

DAVIS, W. M. The Geographical Cycle. In Geographical Journal of The Royal Geographical Society, 14. 1899. p.481-504.

DODDS, P. S.; ROTHMAN, D. H. Unified view of scaling laws for river networks. Physical Review E., New York, v. 59, no. 5. 1999. p. 4865-4877.

DOORNKAMP, J.C. Geomorphological approaches to the study of Neotectonics. Journal of the Geological Society of London, 143. 1986. p. 335-342

DOORNKAMP, J. C; KING, C. A. M. Numerical analysis in Geomorphology: An Introduction. London: Edward Arnold Ltd. 1971. p.372. 
DUNNE, T. LEOPOLD, L. B. Water in environmental planning. New York: Freeman. 1978.

ESTEVES, F.A. Fundamentos de limnologia. 2. ed. Rio de Janeiro: Interciência. 1998.

FARR, T.G.; ROSEN, P.A.; CARO, E.; CRIPPEN, R.; DUREN, R.; HENSLEY, S.; KOBRICK, M.; PALLER, M.; RODRIGUEZ, E.; ROTH, L.; SEAL, D.; SHAFFER, S.; SHIMADA, J.; UMLAND, J.; WERNER, M.; OSKIN, M.; BURBANK, D.; ALSDORF, D. The Shuttle Radar Topography Mission. Review of Geophysics, v.45. 2004.

FREITAS, R.O. Textura de drenagem e sua aplicação geomorfológica. Boletim Paulista de Geografia. São Paulo, v. 11.1952. p.53-57.

FLORENZANO, T. G. (Org). Geomorfologia: conceitos e tecnologias atuais. São Paulo: Oficina de Textos. 2008.

GERASSIMOV, I.P., MECERJAKOV, J.A. Morphoestructure. In FAIRBRIDGE, R.W. (ed). The Encyclopedia of Geomorphology, Reinhold Book, NY. 1968.

GILBERT, G.K. Report on the Geology of the Henry Mountains. In: Geographical and Geological Survay of the Rocky Montain, Powell.1877. p. 120-127.

GREGORY, K.J; WALLING. D.F. Drainage Basin Form and Process - a Geomorphological Approach. John-Wiley \& Sons., New York. 1973. 456p.

GROHMANN, C. H ; RICCOMINI, C. ; STEINER, S.S. SRTM DEMs applications in geomorphology, v. 2. 2008. p. 73-83.

GUERRA, A.J.T; MARÇAL, M.S. Geomorfologia Ambiental. Bertrand Brasil: Rio de Janeiro. 2006. p. 13-16.

GUGLIELMINI, D. Aquarum Fluentium Mensura Nova Methoda Inquisita. Bologna. 1690 .

GUGLIELMINI, D. Della Natura dei Fiumi. Bologna. 1697.

HACK, J. T. Studies of Longitudinal Stream Profiles in Virginia and Maryland. United States Geol. Survery Profiss. Paper, (294-B). 1957.

HACK, J.T. Interpretation of erosional topography in humid temperate regions. American Journal of Science. n. 258. New Haven.1960. p 80-97.

HART, M. G. Geomorphology pure and applied. London, George Allen \& Unwin. 1986. 226p.

HERSCHEL, C.. On the origin of the Chézy formula. J. Ass. Engng. Soc. 18.1897 
HOLLAND, J. H. Hidden Order: How Adaptation Builds Complexity, Addison-Wesley Pub. Co. 2002.

HORTON, R.E. Drainage Basin Characteristics,Trans. Amer. Geophys. Union, 13. 1932. p.350-361.

HORTON, R.E. Erosional development of streams and their drainage basins: hydrophysical approach to quantitative geomorphology. Geological Society American Bulletin, 56(3). 1945. p. 275-370.

ITAIPU BINACIONAL. Instruções de Operação da Itaipu - IOPI. 2000.

ITAIPU BINACIONAL. Relatório de Sustentabilidade. Tiragem 10 mil exemplares. 2006.

IBGE. Atlas multireferencial do Estado do Mato Grosso do Sul. Secretaria de Coordenação e Planejamento. Convênio com o Governo e a Fundação IBGE. 1990. 28 p.

IAPAR - INSTITUTO AGRONÔMICO DO PARANÁ. Cartas climáticas do Estado do Paraná. Londrina: IAPAR, 1 CD-ROM. Versão 1.0. 2000.

JOLY, F. Point de vue sur la géomorphologie. Annales de Géographie, 86. 1977. p. 522541.

JUSTUS, J. de O. Hidrografia. In: IBGE (Ed.). Geografia do Brasil, Região Sul. Rio de Janeiro, Intituto Brasileiro de Geografia e Estatística. 1990. p. 185-218.

KING, L.C. Canons of landscape evolution, Bulletin of the Geological Society of America.Washington, D.C., 64(7). 1953. p. 721-732.

KING, L.C . A geomorfologia do Brasil oriental, Revista Brasileira de Geografia, Rio de Janeiro, 18 (2).1956. p.147-265

LEINZ, V. Contribuição à Geologia dos Derrames Basálticos do Sul do Brasil. Boletim da Faculdade de Filosofia, Ciências e Letras. Universidade de São Paulo, v.3, n. 5. 1949. 61p.

LEITE, P.F. R.M. KLEIN. Vegetação, p. 113-188. In: Ibge (Ed.). Geografia do Brasil, Região Sul. Rio de Janeiro, Intituto Brasileiro de Geografia e Estatística, 1990. 419p

LEOPOLD, L.B.; M.G. WOLMAN; J.P. MILLER. Fluvial Processes in Geomorphology. W.H. Freeman \& Co. San Francisco. 1964. 522 p.

LILLESAND, T. M. KIEFER, R. W. Remote sensing and image interpretation. New York: John Wiley \& Sons, 1979.

LIMA, J. E. F. W. ; LOPES, W. T. A. ; Silva, E.M. ; VIEIRA, M. R. . Boletim de Pesquisa e Desenvolvimento da Embrapa - Diagnóstico hidrossedimentológico da bacia do rio Piquiri. Planaltina, DF: Embrapa Cerrados, 2004. 
MAACK, R. Geografia física do Estado do Paraná. Curitiba, Max Roesner.1968. 350p.

MEZZALIRA, S. Contribuição ao conhecimento da estratigrafia e paleontologia do arenito Bauru. São Paulo: Instituto Geográfico e Geológico, Boletim do Instituto Geográfico e Geológico, v. 51. 1974. 162p.

MINEROPAR - MINERAIS DO PARANÁ S. A. Geologia da Bacia 2003. Disponível em ww.pr.gov.br/mineropar Acesso em 16/01/2007.

MILLER, A. M. Wind Gaps. Science. Vol. XLII, n. 1.086. 1915. 571-573. p.

MONTGOMERY D.R. Predicting landscape-scale erosion using digital elevation models. Comptes Rendus Geoscience, Paris335:, 2003. 1121-1130p.

NAKASHIMA, P. Sistemas Pedológicos da Região Noroeste do Estado do Paraná: Distribuição e Subsídios para o Controle da Erosão. Tese de Doutorado.USP. São Paulo. 1999.

NASA. National Aeronautics and Space Administration 1995a. Mission Overview. Acesso em 2/10/2008, http://southport.jpl.nasa.gov/science/missiono.html.1999.

NIMER, E. Clima, p. 151-158. In: IBGE (Ed.). Geografia do Brasil, Região Sul. Rio de Janeiro, Instituto Brasileiro de Geografia e Estatística, 1990. 419p.

NORTON, G.A. Decision tools for pest management: their role in IPM design and delivery. In: FAO/UNEP/URSS Workshop on Integrated Pest Management. Kishiev, Moldavia. 1990.

ORME， R.A. 2002. Shifting paradigms ingeomorphology: the fate of research ideas in an educational context. Geomorphology 47. p. 325-342

PAGIORO, T. A. Zonação Longitudinal no reservatório de Itaipu com base em variáveis limnológicas - PR- BRAZIL in Variações espaço-temporais das características físicas e químicas da água, material em sedimentação e produtividade primária fitoplanctônica no reservatório de Itaipu. Tese Doutorado em Ecologia de ambientes Aquáticos continentais Ciências Ambientais. UEM, Maringá PR. 1999.

GANDOLFI, N.Bacia do Mogi-Guaçú: Morfometria da Drenagem, Sedimentologia e Investigações Físico-Químicas. Tese (Doutorado em engenharia Civil Geotecnia ) - USP, São Carlos. 1968.

PARANÁ. Atlas do Estado do Paraná. Curitiba, Secretaria de Estado da Agricultura e do Abastecimento. 1990. 74p.

PENCK, A. Morphologie der Erdoberflache. Engelhorn, Stuttgart, 2 volumes. 1894. 
PENCK, W. Die morphologische analyse. Ein kapitel der physikalischen geologie. Stuttgart, J. Engelhorn's Nachf. 1924. 283p.

PINHEIRO, E. S. Comparação entre dados altimétricos Shuttle Radar Topography Mission, Cartas topográficas e GPS: Numa área com relevo escarpado. Revista Brasileira de Cartografia, Presidente Prudente, v. 58. 2006. p. 1-9.

PINTO, L. V. A.; FERREIRA, E.; BOTELHO, S. A.; DAVIDE, A. C. Caracterização física da bacia hidrográfica do Ribeirão Santa Cruz, Lavras, MG e uso conflitante da terra em suas áreas de preservação permanente. Cerne, Lavras, v. 11, n. 1, 2005. p. 49-60.

REID, I.; BARTHURST, J. C.; CARLING, P. A.; WALLING, D. E.; WEBB, B. Sediment Erosion, Transport and Deposition. In: THORNE, C. R.; HEY, R. D. NEWSON, M. D. Applied Fluvial Geomorphology for River Engineering and Management. New York: John Wiley \& Sons. 1997. p. 95-135.

RODRIGUES, C. Geomorfologia aplicada: avaliação de experiências e de instrumentos de planejamento físico-territorial e ambiental brasileiros. São Paulo: 1997, 2v. Tese (Doutorado)

RODRIGUES, C. e ADAMI, S. Técnicas Fundamentais para o Estudo de Bacias Hidrográficas. In: VENTURI, L.A.B. (org.) Praticando Geografia - técnicas de campo e laboratório. São Paulo: Oficina de Textos. 2005.

ROSS, J. L. S. Ecogeografia do Brasil: Subsídios para Planejamento Ambiental. São Paulo: Oficina de Textos. 2006.

SCHUMM, S.A. Evolution of drainage systems and slopes in badlands of Perth Amboy. Geological Society of America Bulletin, n. 67. 1956. p. 597-646.

SILVEIRA, C. T. ; SANTOS, L. J. C. ; FIORI, C. O. ; CANALI, N. E. ; FIORI, A. P. ; SILVA, J. M. F. Cartografia Geomorfológica como subsídio à identificação da Vulnerabilidade Geoambiental do Estado do Paraná. In: VII Simpósio Nacional de Geomorfologia e II Encontro Latino - Americano de Geomorfologia, 2008, Belo Horizonte - BH. Dinâmica e Diversidade de Paisagens. São Paulo : Tecart, v. 1. 2008. p. 1-15.

SMALL, R.J. The study of lanforms. Cambridge: Cambridge University Press. 1977. 486p.

STRAHLER, A.N. Equilibrium theory of erosional slopes approached by frequency distribution analysis, American Journal of Science, 248, 1950. p. 673-696.

STRAHLER, A.N. Dynamic basis of geomorphology, Geological Society of America Bulletin, 63. 1952. 923-938 p. 
STRAHLER, A.N. Quantitative geomorphology of erosional landscapes, Proceedings of the 19th International Geological Congress, Algiers, 1952, section 13, part 3, 1957. 341-354 p.

STRAHLER, A. N. Quantitative geomorphology of drainage basins and channel networks. In: CHOW, V.T. Handbook of apllied hydrology. Nova Iorque: Mc-Graw-Hill, 1964. p. 39-75.

SOARES, P.C.; LANDIM, P.M.B.; FÚLFARO, V.J.; SOBREIRO NETO, A.F. Ensaio de caracterização estratigráfica do Cretáceo no Estado de São Paulo: Grupo Bauru. Revista Brasileira de Geociências, v. 10, n. 3. 1980. p. 177-185.

SOUZA FILHO, E. E., STEVAUX, J. C. Geologia e geomorfologia do complexo rio BaiaCurutuba-Ivinhema In: A planície de inundação do alto rio Paraná.1 ed.Maringá: EDUEM, v.1. 1997. p.01- 45.

SUGUIO, K., BIGARELLA, J. Ambientes Fluviais. 2ªEd. Florianópolis: editora da UFSC. 1990.

THORNBURY, W, D. Principles of Geomorphology. New York, John Wiley \& Sons, Inc. 1957. 618p.

THORNTON, K.W. Sedimentary processes in Reservoir limnology: ecological perspectives. Edited by K.W, B.1.Kimmel, and F.E Payne. John Wiley and sons, New York. 1990. p. 133173.

TOLENTINO, M.; GANDOLFI, N; PARAGUASSU, A. B. Estudo Morfométrico das Bacias Hidrográficas do Planalto de São Carlos-SP. REVISTA BRASILEIRA DE GEOGRAFIA, v. 4, n. 30.1968. p. 42-50,

TRICART, J. Divisão morfoclimática do Brasil Atlântico Central. Boletim Paulista de Geografia, São Paulo. Assoc. dos Geóg. Bras., (31): 1959. 3 - 44.

TUNDISI, J.G. Represas do Paraná Superior: Lmnologia e bases científicas para o gerenciamento. In Conferencias de Limnologia La Prata: Instituto de Limnologia "Dr. R. " Ringuelet". Edited by a Boltovskoy, and H.L. López. 1993. p.41-52.

VENTURI, L. A. B. (Org.) Praticando Geografia - técnicas de campo e laboratório. 1a. ed. São Paulo: Oficina de Textos, v. 1. 2005.. 239 p.

VERSTAPPEN, H. T..Applied Geomorphology: Geomorphological Surveys for Environment. Amsterdam, Elsevier. 1983

VIEIRA, N.M. Estudo geomorfológico das boçorocas de Franca (SP). Franca. (Tese de Doutorado)-Instituto de História e Serviço Social/UNESP, 1978. 225p. 
VILLELA, S.M.; MATTOS, A. Hidrologia aplicada. São Paulo: McGraw-Hill do Brasil, 1975. 245p.

WARD, A. D.; TRIMBLE, S. W. Environmental hydrology. 2ed. New York: Lewis publishers. $1995.475 \mathrm{p}$

WILLIAMS, G. P. Sediment concentration versus water discharge during single hydrologic events in rivers. Journal of Hydrology, Amsterdam, v. 111. 1989. p. 89-106.

WISLER, C. O.; BRATER, E. F. Hidrologia. Tradução e publicação de Missão NorteAmericana pela Cooperação Econômica e Técnica no Brasil. Rio de Janeiro: Ao Livro Técnico S.A., 1964.

YANG, C. T. Sediment transport: Theory and practice. New York: The McGraw-Hill Companies, Inc. 1996. 396p. 


\section{APENDICES}

\section{APÊNDICE A - Curva hipsográfica e de volume}

Tabela 12: Elementos para obtenção da curva hipsográfica e de volume da bacia do rio Iguatemi

\begin{tabular}{|c|c|c|c|c|c|}
\hline Intervalo & Ponto Médio & Cota & $\mathrm{A}$ & $\mathrm{a}$ & $\mathrm{a} / \mathrm{A}$ \\
\hline $229-250$ & 239.5 & 229 & 78.413 & 7978.405 & 0.00 \\
\hline $250-300$ & 275 & 279 & 643.948 & 7899.991 & 0.00 \\
\hline $300-350$ & 325 & 329 & 2350.391 & 7256.043 & 0.00 \\
\hline $350-400$ & 375 & 379 & 3018.742 & 4905.652 & 0.00 \\
\hline $400-450$ & 425 & 429 & 1461.991 & 1886.909 & 0.00 \\
\hline $450-500$ & 475 & 479 & 293.648 & 424.919 & 0.00 \\
\hline $500-550$ & 525 & 529 & 125.056 & 131.271 & 0.00 \\
\hline $550-596$ & 573.0 & 596 & 6.215 & 6.215 & 0.00 \\
\hline Área Total & & & 7978.405 & & \\
\hline
\end{tabular}

Continuação...

\begin{tabular}{|c|c|c|c|c|c|c|c|c|}
\hline Intervalo & Ponto Médio & $\mathrm{h}$ & $\mathrm{h} / \mathrm{H}$ & $\mathrm{v}$ & $\mathrm{V}$ & $\mathrm{IH}$ & $\mathrm{IV}$ & IH-IV \\
\hline $229-250$ & 239.5 & 0.00 & 0.00 & 2928074488 & 1 & & & \\
\hline $250-300$ & 275 & 50.00 & 0.14 & 2504297210 & 0.855271005 & 0.136 & 0.126 & 0.009 \\
\hline $300-350$ & 325 & 100.00 & 0.27 & 1937363481 & 0.661651023 & 0.129 & 0.103 & 0.026 \\
\hline $350-400$ & 375 & 150.00 & 0.41 & 1064526397 & 0.36355851 & 0.104 & 0.070 & 0.034 \\
\hline $400-450$ & 425 & 200.00 & 0.54 & 315113869.8 & 0.107618119 & 0.058 & 0.032 & 0.026 \\
\hline $450-500$ & 475 & 250.00 & 0.68 & 49715499.6 & 0.016978905 & 0.020 & 0.008 & 0.011 \\
\hline $500-550$ & 525 & 300.00 & 0.82 & 8795177.1 & 0.003003741 & 0.005 & 0.001 & 0.003 \\
\hline $550-596$ & 573.0 & 367.00 & 1.00 & 0 & 0 & 0.002 & 0.000 & 0.001 \\
\hline Área Total & & & & & & 0.453 & 0.342 & 0.111 \\
\hline
\end{tabular}


Tabela 13: Elementos para obtenção da curva hipsográfica e de volume da bacia do rio Piquiri.

\begin{tabular}{|c|c|c|c|c|c|}
\hline Intervalo & Ponto Médio & Cota & $\mathrm{A}$ & $\mathrm{a}$ & $\mathrm{a} / \mathrm{A}$ \\
\hline $229-250$ & 239.5 & 229 & 43.983 & 21599.9784 & 0.0010000 \\
\hline $250-300$ & 275 & 279 & 602.5797 & 21555.9954 & 0.0009980 \\
\hline $300-350$ & 325 & 329 & 1649.646 & 20953.4157 & 0.0009701 \\
\hline $350-400$ & 375 & 379 & 2505.8241 & 19303.7697 & 0.0008937 \\
\hline $400-450$ & 425 & 429 & 2668.2012 & 16797.9456 & 0.0007777 \\
\hline $450-500$ & 475 & 479 & 2411.4717 & 14129.7444 & 0.0006542 \\
\hline $500-550$ & 525 & 529 & 2120.9202 & 11718.2727 & 0.0005425 \\
\hline $550-600$ & 575 & 579 & 1955.4003 & 9597.3525 & 0.0004443 \\
\hline $600-650$ & 625 & 629 & 1681.9056 & 7641.9522 & 0.0003538 \\
\hline $650-700$ & 675 & 679 & 1417.9932 & 5960.0466 & 0.0002759 \\
\hline $700-750$ & 725 & 729 & 1138.6008 & 4542.0534 & 0.0002103 \\
\hline $750-800$ & 775 & 779 & 830.2608 & 3403.4526 & 0.0001576 \\
\hline $800-850$ & 825 & 829 & 619.0569 & 2573.1918 & 0.0001191 \\
\hline $850-900$ & 875 & 879 & 493.2504 & 1954.1349 & 0.0000905 \\
\hline $900-950$ & 925 & 929 & 421.0632 & 1460.8845 & 0.0000676 \\
\hline $950-1000$ & 975 & 979 & 373.5414 & 1039.8213 & 0.0000481 \\
\hline $1000-1050$ & 1025 & 1029 & 319.5063 & 666.2799 & 0.0000308 \\
\hline $1050-1100$ & 1075 & 1079 & 200.7144 & 346.7736 & 0.0000161 \\
\hline $1100-1150$ & 1125 & 1129 & 91.4607 & 146.0592 & 0.0000068 \\
\hline $1150-1200$ & 1175 & 1179 & 45.3114 & 54.5985 & 0.0000025 \\
\hline $1200-1243$ & 1221.5 & 1243 & 9.2871 & 9.2871 & 0.0000004 \\
\hline Área Total & & & 21599.9784 & & \\
\hline
\end{tabular}




\section{Continuação...}

\begin{tabular}{|c|c|c|c|c|c|c|c|c|}
\hline Intervalo & Ponto Médio & $\mathrm{h}$ & $\mathrm{h} / \mathrm{H}$ & $\mathrm{v}$ & $\mathrm{v} / \mathrm{V}$ & $\mathrm{IH}$ & $\mathrm{IV}$ & $\mathrm{IH}-\mathrm{IV}$ \\
\hline $229-250$ & 239.5 & 0 & 0 & 21902378.1 & 1.0000000 & & & \\
\hline $250-300$ & 275 & 50 & 0.049309665 & 20779979.57 & 0.9487545 & 0.049 & 0.048 & 0.001 \\
\hline $300-350$ & 325 & 100 & 0.098619329 & 19151421.95 & 0.8743992 & 0.049 & 0.045 & 0.004 \\
\hline $350-400$ & 375 & 150 & 0.147928994 & 16678457.02 & 0.7614907 & 0.046 & 0.040 & 0.006 \\
\hline $400-450$ & 425 & 200 & 0.197238659 & 13673527.72 & 0.6242942 & 0.041 & 0.034 & 0.007 \\
\hline $450-500$ & 475 & 250 & 0.246548323 & 10795124.72 & 0.4928745 & 0.035 & 0.028 & 0.008 \\
\hline $500-550$ & 525 & 300 & 0.295857988 & 8366846.708 & 0.3820063 & 0.030 & 0.022 & 0.008 \\
\hline $550-600$ & 575 & 350 & 0.345167653 & 6372642.06 & 0.2909566 & 0.024 & 0.017 & 0.008 \\
\hline $600-650$ & 625 & 400 & 0.394477318 & 4692158.651 & 0.2142306 & 0.020 & 0.012 & 0.007 \\
\hline $650-700$ & 675 & 450 & 0.443786982 & 3361466.282 & 0.1534749 & 0.016 & 0.009 & 0.006 \\
\hline $700-750$ & 725 & 500 & 0.493096647 & 2334615.448 & 0.1065919 & 0.012 & 0.006 & 0.006 \\
\hline $750-800$ & 775 & 550 & 0.542406312 & 1579202.006 & 0.0721019 & 0.009 & 0.004 & 0.005 \\
\hline $800-850$ & 825 & 600 & 0.591715976 & 1065301.405 & 0.0486386 & 0.007 & 0.003 & 0.004 \\
\hline $850-900$ & 875 & 650 & 0.641025641 & 711305.1036 & 0.0324762 & 0.005 & 0.002 & 0.003 \\
\hline $900-950$ & 925 & 700 & 0.690335306 & 458717.733 & 0.0209437 & 0.004 & 0.001 & 0.003 \\
\hline $950-1000$ & 975 & 750 & 0.73964497 & 274512.8232 & 0.0125335 & 0.003 & 0.001 & 0.002 \\
\hline $1000-1050$ & 1025 & 800 & 0.788954635 & 142583.8986 & 0.0065100 & 0.002 & 0.000 & 0.001 \\
\hline $1050-1100$ & 1075 & 850 & 0.8382643 & 56870.8704 & 0.0025966 & 0.001 & 0.000 & 0.001 \\
\hline $1100-1150$ & 1125 & 900 & 0.887573964 & 16650.7488 & 0.0007602 & 0.001 & 0.000 & 0.000 \\
\hline $1150-1200$ & 1175 & 950 & 0.936883629 & 3494.304 & 0.0001595 & 0.000 & 0.000 & 0.000 \\
\hline $1200-1243$ & 1221.5 & 1014 & 1 & 0 & 0.0000000 & 0.000 & 0.000 & 0.000 \\
\hline Área Total & & & & & & 0.353 & 0.273 & 0.080 \\
\hline
\end{tabular}




\section{APÊNDICE B - Análises hidrossedimentológicas}
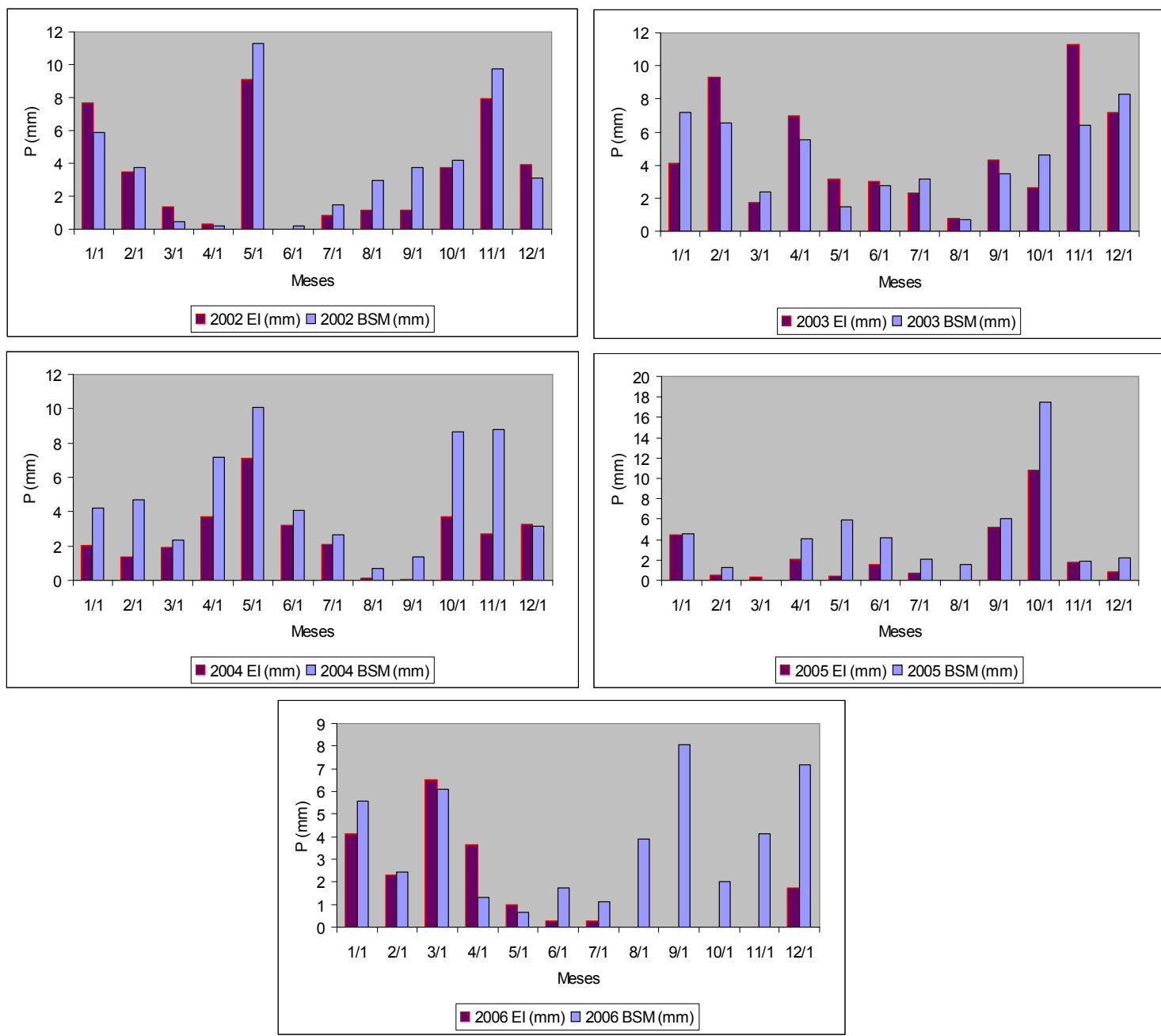

Figura 50: Médias diárias das precipitações das estações de monitoramento Estrada Iguatemi e Balsa Santa Maria no período 2002-2006. 

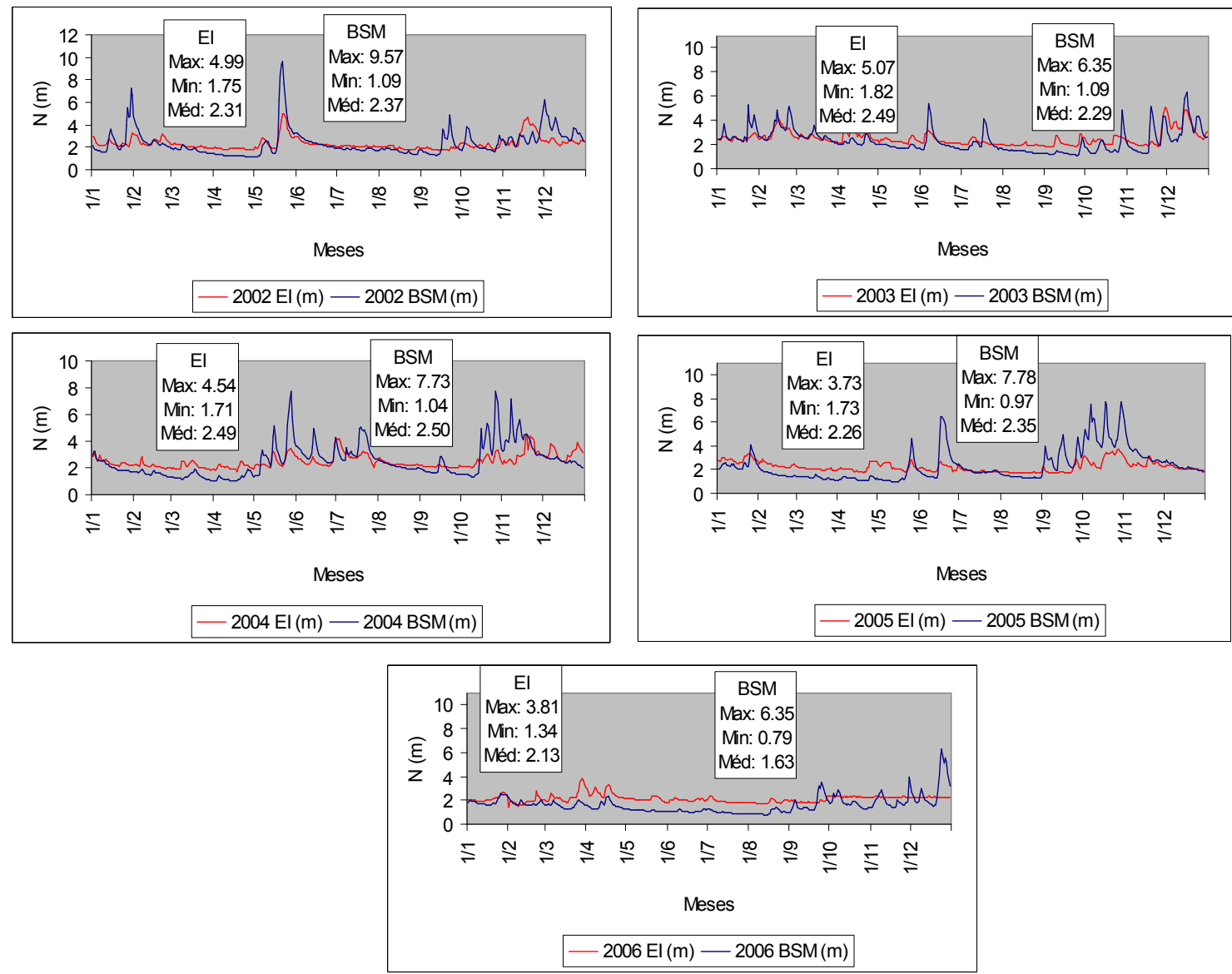

Figura 51: Médias diárias do nível fluviométrico das estações de monitoramento Estrada Iguatemi e Balsa Santa Maria no período 2002-2006. 

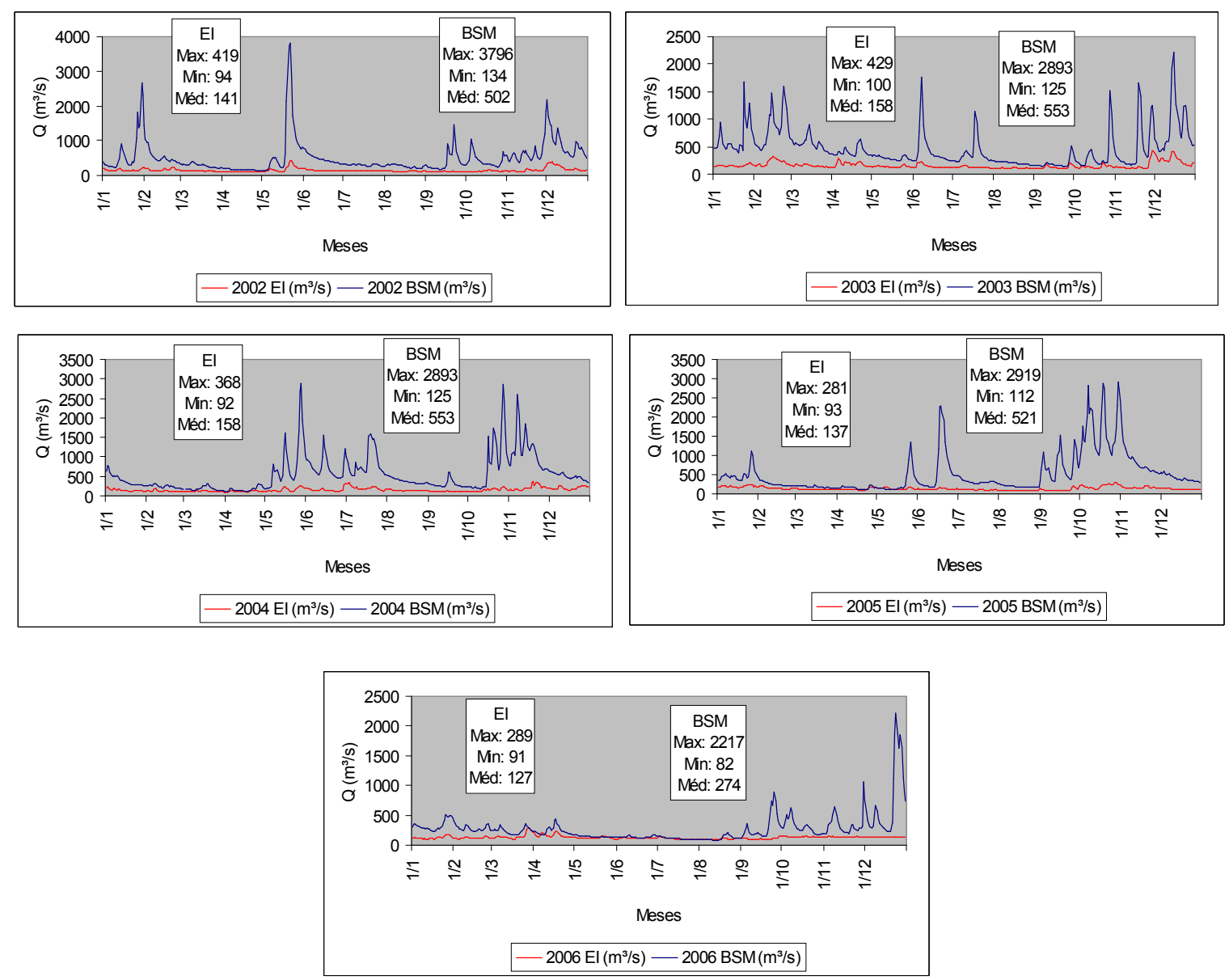

Figura 52: Médias diárias da descarga líquida das estações de monitoramento Estrada Iguatemi e Balsa Santa Maria no período 2002-2006. 
Quadro 7: Equações para obtenção da descarga sólida de sedimentos em suspensão.

\begin{tabular}{|l|l|l|}
\hline & Estrada Iguatemi & Balsa Santa Maria \\
\hline 2002 & $0.0089^{*} \mathrm{Q}^{2.273}$ & $0.0003345^{*} \mathrm{Q}^{2.479}$ \\
\hline 2003 & $0.0136^{*} \mathrm{Q}^{2.224}$ & $0.0312081^{*} \mathrm{Q}^{1.822}$ \\
\hline 2004 & $0.0151^{*} \mathrm{Q}^{2.270}$ & $0.0220669^{*} \mathrm{Q}^{1.869}$ \\
\hline 2005 & $0.00003 * \mathrm{Q}^{3.397}$ & $0.0089674^{*} \mathrm{Q}^{2.030}$ \\
\hline 2006 & $0.0269^{*} \mathrm{Q}^{2.144}$ & $0.0000266^{*} \mathrm{Q}^{3.031}$ \\
\hline
\end{tabular}
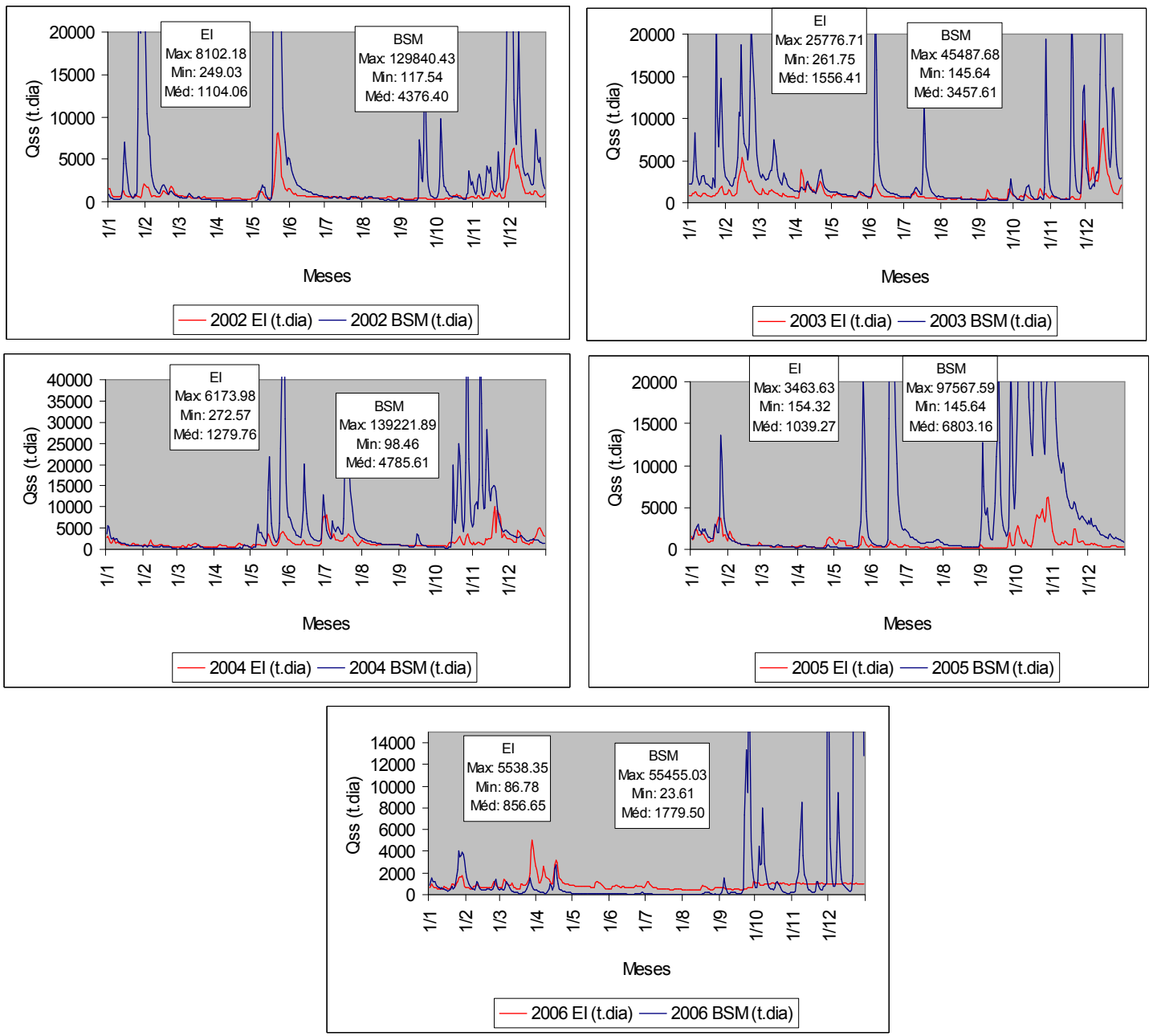

Figura 53: Médias diárias de descarga sólida de sedimentos nas estações de monitoramento Estrada Iguatemi e Balsa Santa Maria no período 2002-2006. 

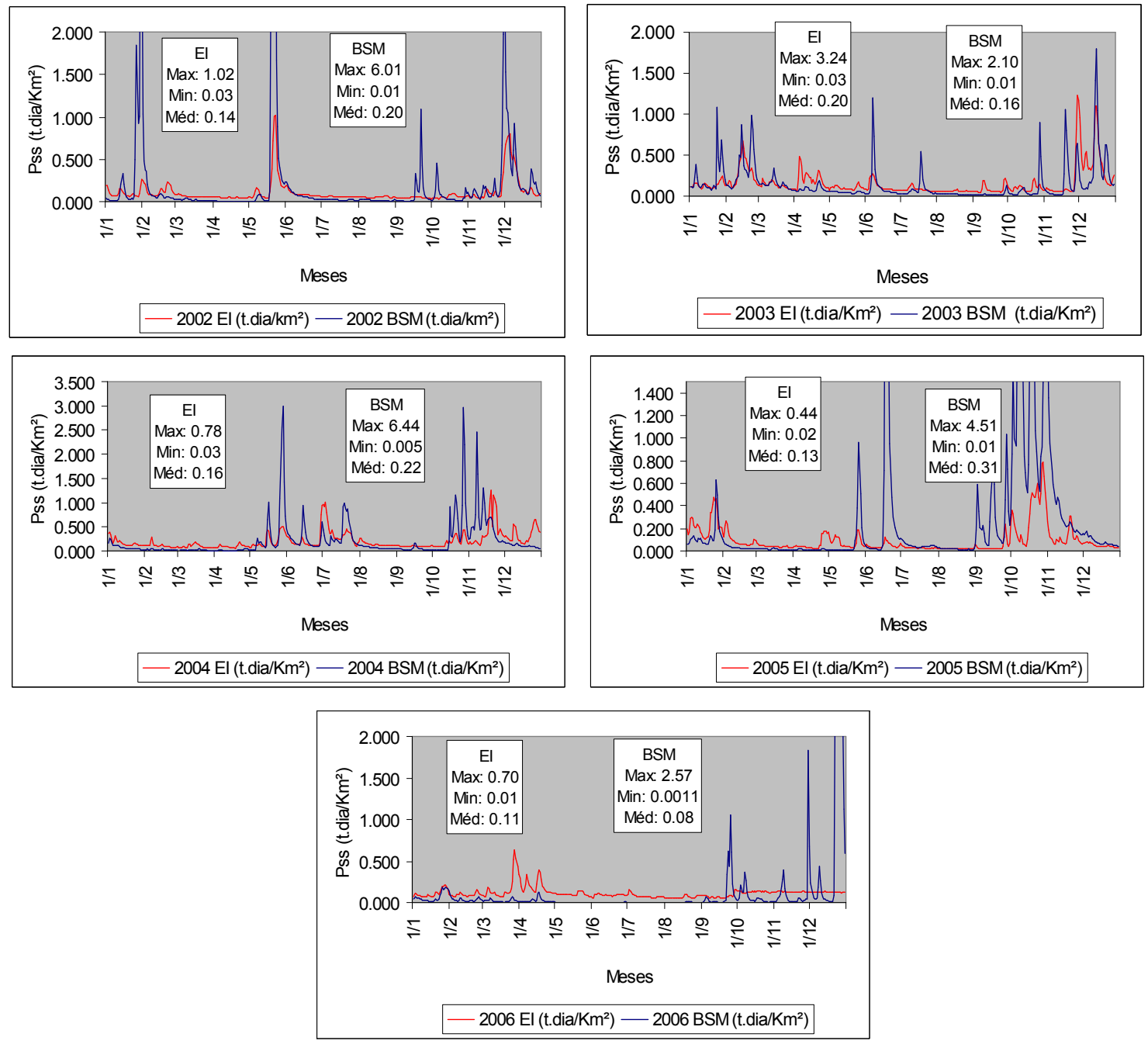

Figura 54: Médias diárias da produção específica de sedimentos em suspensão nas estações de monitoramento Estrada Iguatemi e Balsa Santa Maria no período 2002-2006. 
Tabela 14: Médias mensais dos parâmetros hidrossedimentológicos do período 2002-2006 das estações referentes as bacias hidrográficas analisadas.

\begin{tabular}{|c|c|c|c|c|c|c|}
\hline & $\begin{array}{c}\text { Estrada Iguatemi } \\
\mathrm{P}(\mathrm{ml})\end{array}$ & $\begin{array}{c}\text { Balsa Santa } \\
\text { Maria P }(\mathrm{ml})\end{array}$ & $\begin{array}{c}\text { Estrada Iguatemi } \\
\mathrm{Q}\left(\mathrm{m}^{3} / \mathrm{s}\right)\end{array}$ & $\begin{array}{c}\text { Balsa Santa } \\
\text { Maria Q }\left(\mathrm{m}^{3} / \mathrm{s}\right)\end{array}$ & $\begin{array}{c}\text { Estrada } \\
\text { Iguatemi }(\mathrm{m})\end{array}$ & $\begin{array}{c}\text { Balsa Santa } \\
\text { Maria }(\mathrm{m})\end{array}$ \\
\hline Jan & 4.49 & 5.47 & 179.08 & 578.69 & 2.47 & 2.61 \\
\hline Fev & 3.40 & 3.73 & 170.72 & 436.38 & 2.42 & 2.20 \\
\hline Mar & 2.36 & 2.26 & 149.87 & 292.24 & 2.22 & 1.73 \\
\hline Abr & 3.35 & 3.66 & 173.97 & 245.16 & 2.28 & 1.51 \\
\hline Mai & 4.15 & 5.91 & 205.35 & 502.81 & 2.41 & 2.26 \\
\hline Jun & 1.62 & 2.58 & 149.18 & 427.62 & 2.27 & 2.33 \\
\hline Jul & 1.25 & 2.11 & 150.76 & 379.79 & 2.21 & 2.03 \\
\hline Ago & 0.42 & 1.95 & 123.35 & 239.46 & 1.96 & 1.52 \\
\hline Set & 2.14 & 4.52 & 119.94 & 417.09 & 2.00 & 2.02 \\
\hline Out & 4.19 & 7.39 & 162.93 & 772.75 & 2.44 & 2.86 \\
\hline Nov & 4.75 & 6.19 & 183.48 & 725.81 & 2.67 & 2.89 \\
\hline Dez & 3.40 & 4.78 & 192.79 & 672.67 & 2.68 & 2.91 \\
\hline
\end{tabular}

Tabela 15: Médias mensais dos parâmetros hidrossedimentológicos do período 2002-2006 das estações referentes as bacias hidrográficas analisadas.

\begin{tabular}{|c|c|c|c|c|}
\hline & $\begin{array}{c}\text { Estrada Iguatemi Css } \\
(\mathrm{mg} / \mathrm{l})\end{array}$ & $\begin{array}{c}\text { Balsa Santa Maria } \\
\text { Css }(\mathrm{mg} / \mathrm{l})\end{array}$ & $\begin{array}{c}\text { Estrada Iguatemi Pss } \\
\left(\mathrm{t} / \mathrm{km}^{2} / \mathrm{dia}\right)\end{array}$ & $\begin{array}{c}\text { Balsa Santa Maria Pss } \\
\left(\mathrm{t} / \mathrm{km}^{2} / \mathrm{dia}\right)\end{array}$ \\
\hline Jan & 118.31 & 73.78 & 0.25 & 0.27 \\
\hline Fev & 87.21 & 57.87 & 0.19 & 0.13 \\
\hline Mar & 84.60 & 45.88 & 0.16 & 0.06 \\
\hline Abr & 122.73 & 32.25 & 0.26 & 0.04 \\
\hline Mai & 104.75 & 63.90 & 0.29 & 0.21 \\
\hline Jun & 52.16 & 46.06 & 0.09 & 0.13 \\
\hline Jul & 42.72 & 29.28 & 0.08 & 0.07 \\
\hline Ago & 45.82 & 18.76 & 0.06 & 0.02 \\
\hline Set & 57.49 & 54.22 & 0.09 & 0.49 \\
\hline Out & 104.58 & 65.08 & 0.19 & 0.32 \\
\hline Nov & 120.27 & 73.96 & 0.27 & 0.29 \\
\hline Dez & 133.73 & 87.61 & 0.31 & \\
\hline
\end{tabular}

